\title{
Ground-Water Levels and Flow at Selected Study Sites in the Walnut Creek Management System Evaluation Area, Boone and Story Counties, lowa, 1991-93
}

\section{By ROBERT C. BUCHMILLER}

U.S. GEOLOGICAL SURVEY

Water-Resources Investigations Report 95-4109

Prepared in cooperation with the

U.S. DEPARTMENT OF AGRICULTURE, AGRICULTURAL RESEARCH SERVICE 


\section{U.S. DEPARTMENT OF THE INTERIOR}

\section{BRUCE BABBITT, Secretary}

\section{U.S. GEOLOGICAL SURVEY}

Gordon P. Eaton, Director

For additional information write to:

District Chief

U.S. Geological Survey

Box 1230

lowa City, IA 52244-1230
Copies of this report can be purchased from:

U.S. Geological Survey

Earth Science Information Center

Open-File Reports Section

Box 25286, MS 517

Denver Federal Center

Denver, CO 80225 


\section{CONTENTS}

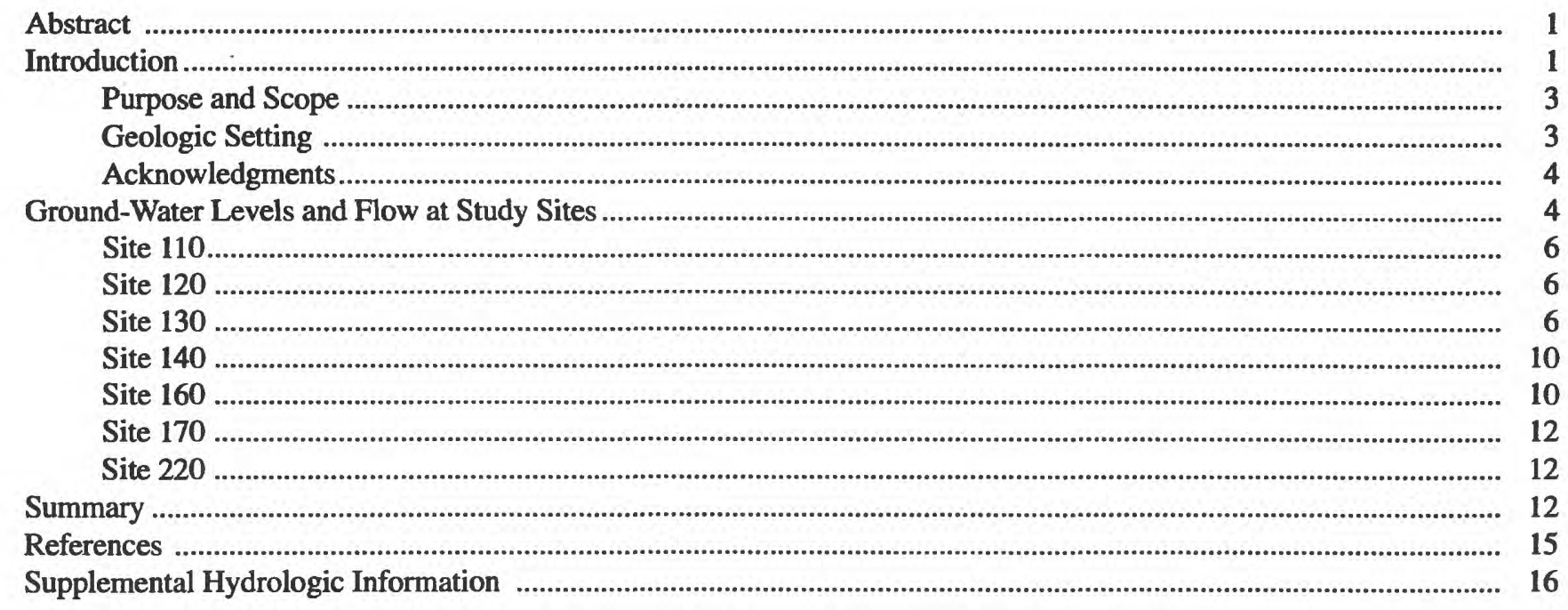

\section{FIGURES}

1. Maps showing location of Walnut Creek Management Systems Evaluation Area and selected study sites in Boone and Story Counties, Iowa..

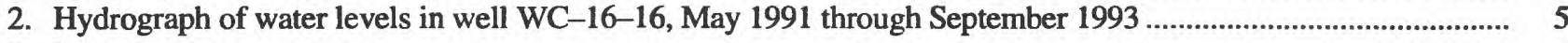

3-8. Map showing:

3. Potentiometric surface, site 110, June 1,1992

4. Potentiometric surface, sites 120 and 160, June 4, 1992 ............................................................................... 8

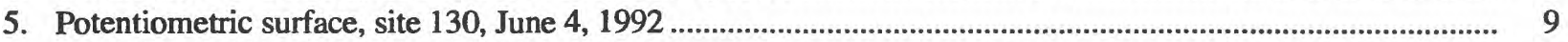

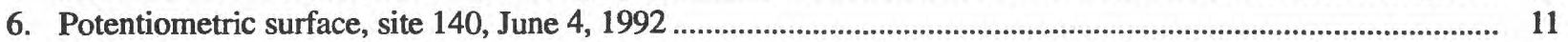

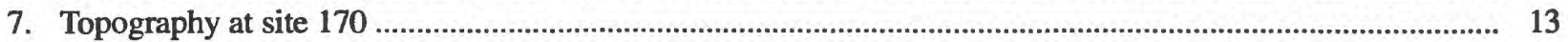

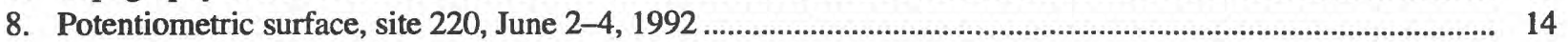

\section{TABLES}

1. Summary of particle-size data for Iowa glacial deposits

2. Descriptive logs of selected boreholes drilled in the Walnut Creek Watershed, Boone and Story Counties, Iowa . 16

3. Local numbers and construction data for selected wells drilled in the Walnut Creek Watershed, Boone and Story Counties, Iowa

4. Water-level measurements in selected wells in the Walnut Creek Watershed, Boone and Story Counties, Iowa, May 1991-September 1993 
CONVERSION FACTORS, ABBREVIATIONS, AND VERTICAL DATUM

\begin{tabular}{rcl}
\hline Multiply & By & To obtain \\
\hline inch (in.) & Length & \\
foot (ft) & 25.4 & millimeter \\
mile (mi) & 0.3048 & meter \\
& 1.609 & kilometer \\
square mile $\left(\mathrm{mi}^{2}\right)$ & Area & square kilometer \\
& 2.590 & \\
cubic foot per second $\left(\mathrm{ft}^{3} / \mathrm{s}\right)$ & Flow & cubic meter per second \\
\hline
\end{tabular}

Sea level: In this report, "sea level" refers to the National Geodetic Vertical Datum of 1929—a geodetic datum derived from a general adjustment of the first-order level nets of the United States and Canada, formerly called Sea Level Datum of 1929. 


\title{
Ground-Water Levels and Flow at Selected Study Sites in the Walnut Creek Management System Evaluation Area, Boone and Story Counties, lowa, 1991-93
}

\author{
By Robert C. Buchmiller
}

\section{Abstract}

Data collected from May 1991 through September 1993 to determine seasonal fluctuations in ground-water levels and to estimate directions of ground-water flow in the saturated zone at selected study sites at the Iowa Management Systems Evaluation Area in the Walnut Creek Watershed are presented. The Walnut Creek Watershed is located on glacial deposits of Wisconsinan age in central Iowa and includes about 20 square miles. The upper glacial materials appear to be supraglacial tills rather than basal glacial tills and contain both oxidized and unoxidized zones. Water levels were measured in 102 wells from 38 locations at 7 study sites in the watershed. Water levels fluctuated in response to local climatic conditions and ranged from at or near the land surface to more than 30 feet below land surface. In general, ground water flowed towards Walnut Creek or large drainage tiles. Potentiometric-surface maps at the selected study sites can be used to determine which locations might be affected by agricultural management practices in place at each site.

\section{INTRODUCTION}

Recognition of the potential impacts of agricultural management systems on surface and ground water has resulted in a Federal program entitled the Midwest Water Quality Initiative. The Management Systems Evaluation Area (MSEA) program was begun in 1990 as a multi-agency effort by the U.S. Geologi- cal Survey (USGS) and the Agricultural Research Service and Cooperative State Research Service of the U.S. Department of Agriculture as part of the Initiative. MSEAs were established in five States-Iowa, Minnesota, Missouri, Nebraska, and Ohio. The study areas in these States were selected to be representative of typical hydrogeologic environments within the corn- and soybean-growing areas of the Midwest (Soenksen and others, 1992).

The focus of study for the overall MSEA program in Iowa is to evaluate the impact of current and emerging farming systems and practices on water quality. This research is being conducted at four study areas in Iowa (fig. 1) that represent three types of hydrogeologic settings. The study areas are: near Nashua, thin glacial till overlying bedrock; near Treynor, thick loess; and two areas near Ames, thick glacial till.

The USGS is conducting surface-water and ground-water research at the Walnut Creek study area near Ames. This study area is a watershed of about $20 \mathrm{mi}^{2}$ and is located about $3 \mathrm{mi}$ south of Ames in eastern Boone County and western Story County. The Walnut Creek Watershed has its headwaters on nearly level terrain of western Story County and flows eastward to its confluence with the South Skunk River. The stream gradient becomes steeper as it approaches the flood plain of the South Skunk River. The mean daily discharge of Walnut Creek where it enters the flood plain was $14.0 \mathrm{ft}^{3} / \mathrm{s}$ in 1992 . The total relief of the watershed is about $200 \mathrm{ft}$.

The USGS role in the Iowa MSEA is centered on three objectives: (1) to estimate ground-water flow in the saturated zone at selected study sites within the watershed; (2) to evaluate the ability of the Precipitation-Runoff Modeling System (PRMS), a surface- 


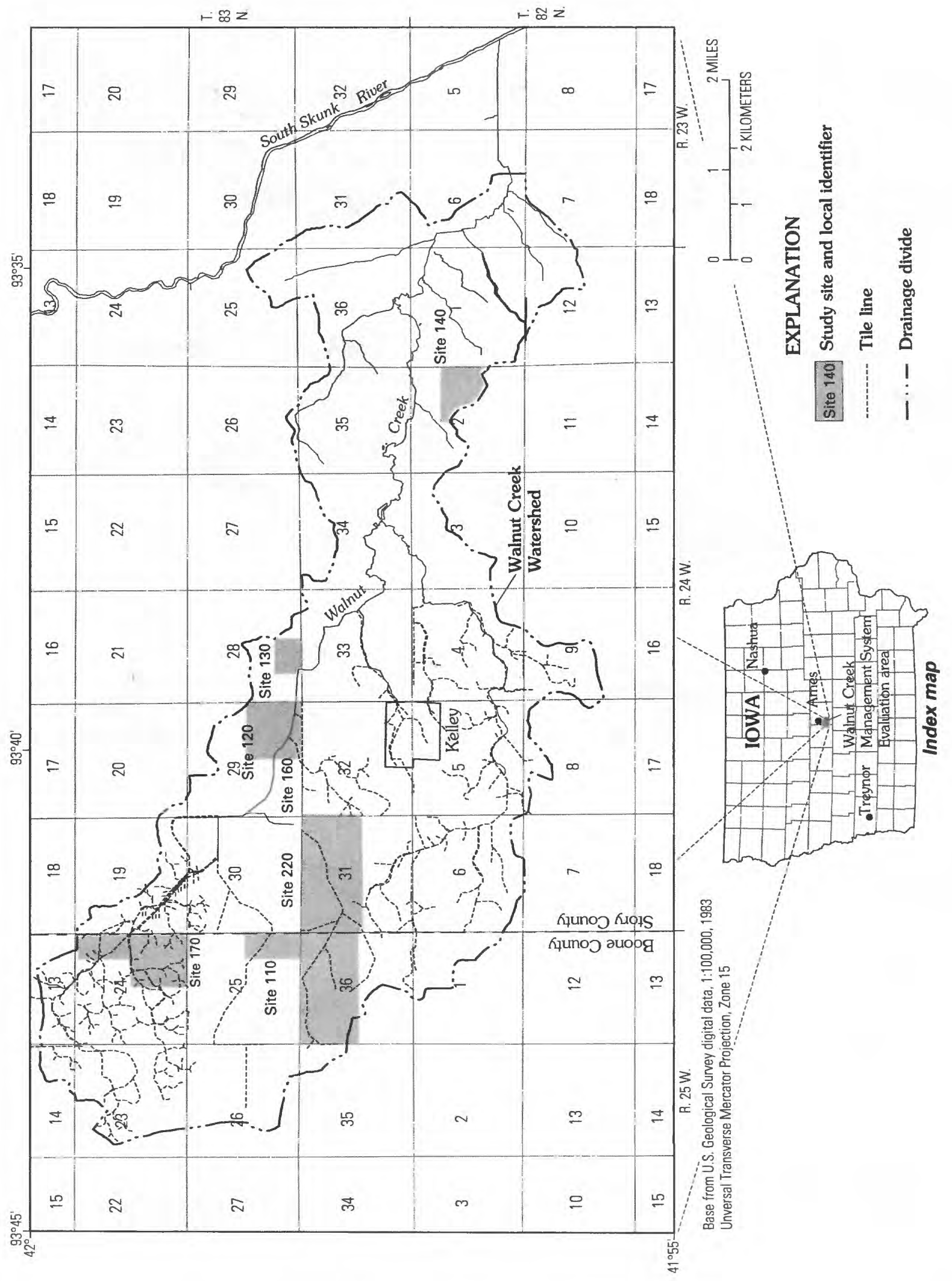


water digital modeling package of the USGS (Leavesley and others, 1983), to simulate the major flow processes in the watershed; and (3) to relate the loadings of agricultural chemicals and sediment observed in streamflow from the watershed to the major flow processes.

\section{Purpose and Scope}

The purpose of this report is to present the results obtained from May 1991 through September 1993 for objective 1. Descriptions of the geologic materials penetrated during the drilling of observation wells, water-level fluctuations, and generalized lateral ground-water-flow directions at selected study sites are presented. The information presented can be used to assist interpretation of the results of water-quality analyses on samples collected from observation wells in the watershed and thereby help to determine the effects of agricultural management practices on water quality.

\section{Geologic Setting}

Walnut Creek Watershed is located on glacial deposits of Wisconsinan age in central Iowa. The watershed is near the southern boundary of the Des Moines Lobe landform that resulted from glaciers that advanced into Iowa between 12,000 and 14,000 years ago (Prior, 1991). The Des Moines Lobe is characterized by low-relief topography, a poorly developed natural drainage system, and soils that have formed on the glacial drift. Wisconsinan drift overlies older pre-Illinoian glacial deposits in the study area. The glacial deposits within the watershed are as much as $300 \mathrm{ft}$ thick and overlie sedimentary bedrock of Mississippian and Pennsylvanian age. These glacial deposits, because of their clay-rich content, do not form aquifers.

Wisconsinan glacial deposits of the Des Moines Lobe have been categorized by Kemmis and others (1981) into two primary units according to their mode of deposition. Supraglacial sediments refer to material that was incorporated into or lying on the surface of the ice and deposited as the ice melted. Basal till refers to deposits formed beneath the glacier. Supraglacial sediments are till-like deposits interbedded with silty and sandy deposits. Supraglacial sediments are variable in texture and geotechnical properties, whereas basal till is characterized by uniform texture and geotechnical properties. Kemmis and others (1981) report the mean percentages of clay, silt, and sand for supraglacial sediments of the Des Moines Lobe to be $14.1,42.3$, and 43.6 , respectively, with standard deviations of 5.2,14.4, and 15.0, respectively. They also report that basal till in the same area has clay, silt, and sand percentages of $15.5,36.7$, and 47.7 , respectively, with standard deviations of $2.4,3.2$, and 3.4, respectively. The smaller standard deviations of the basal till particle sizes indicates its more uniform composition.

In comparison, Hallberg (1980) summarizes particle-size percentages for clay, silt, and sand of preIllinoian till in east-central Iowa as $22.6,37.0$, and 40.0 , respectively, with standard deviations of $4.1,5.7$, and 6.5, respectively. In general, it appears from these reports that pre-Illinoian till in Iowa contains a larger percentage of clay and a smaller percentage of sand than Wisconsinan glacial deposits.

Glacial deposits in the study area also can be divided into two other classifications-oxidized material and unoxidized material. The oxidized material is glacial material that has been exposed to near land-surface conditions. The oxidized material is tan to brown in color and fractured. The minerals that comprise the clay matrix have been oxidized or selectively leached by water moving through the material. The unoxidized material is characterized by its dark-gray color and the absence of apparent fractures. Often there is a transition zone between the oxidized material and the unoxidized material. This transition zone contains evidence of fracturing, and areas of the material near the fractures appear oxidized whereas interfracture areas appear unoxidized. Precipitates of calcium carbonate and calcium sulfate and oxidation rinds appear within and along fractures in this transition zone, indicating open fractures and preferential ground-water flow. Oxidation zones occur in both Wisonsinan and pre-Illinoian deposits.

The oxidized and unoxidized materials in much of the upper 20 to $30 \mathrm{ft}$ of the glacial deposits throughout the Walnut Creek Watershed appear to be supraglacial tills rather than basal tills. These upper materials contain substantially greater percentages of sand content than those reported for basal Wisconsinan-age tills in Iowa (Kemmis and others, 1981). The presence of a very sandy zone within the upper $10 \mathrm{ft}$ of material at many locations indicates these materials might have been sorted during deposition. Table 1 shows a summary of the percentages of sand, silt, and clay at 
Table 1. Summary of particle-size data for lowa glacial deposits

\begin{tabular}{|c|c|c|c|}
\hline \multirow[b]{2}{*}{ Deposit } & \multicolumn{3}{|c|}{ Percentage of } \\
\hline & Sand & Silt & Clay \\
\hline $\begin{array}{l}\text { Wisconsinan supraglacial } \\
\text { till }^{1}\end{array}$ & 43.6 & 42.3 & 14.1 \\
\hline Wisconsinan basal till ${ }^{1}$ & 47.8 & 36.7 & 15.5 \\
\hline Pre-Illinoian till ${ }^{2}$ & 40.2 & 37.2 & 22.6 \\
\hline $\begin{array}{l}\text { Till in Walnut Creek Water- } \\
\text { shed at well site WC- }-4 \\
\text { (mean of four samples } \\
\text { from depths of } 5.5 \text { to } \\
25 \text { feet below land } \\
\text { surface) }\end{array}$ & 55.2 & 25.5 & 19.3 \\
\hline
\end{tabular}

one well site in the Walnut Creek Watershed compared to percentages of sand, silt, and clay for glacial till in Iowa.

\section{Acknowledgments}

The author acknowledges and thanks the staff and management of the National Soil Tilth Laboratory, Agricultural Research Service, Ames, Iowa, for their assistance and cooperation in this study. Karen Keck and Donna Schmitz of that agency arranged for permission to install observation wells and make measurements on private property. They also collected and collated the water-level information from the observation wells that is used in this report. The cooperation of local landowners and farmers also is greatly appreciated; without them this study would not have been possible.

\section{GROUND-WATER LEVELS AND FLOW AT STUDY SITES}

Fields and subdrainage basins within Walnut Creek Watershed were selected for study of the effects of land use and farm-management practices on water quality by the Agricultural Research Service. The areas were selected to provide information on a variety of land use and farm-management practices. Most of the land within the watershed is used for the production of corn and soybeans. Drainage tile lines have been installed beneath the plow layer in many fields throughout the watershed to facilitate drainage, particularly in the poorly drained areas of the western part of the watershed. The tile lines form a quasidendritic drainage network that discharges to the stream network at various points throughout the watershed. The tile lines supply water to the stream throughout all but the driest of times. The location of some, but not all, tile lines is known or can be inferred from surface drainage patterns. The approximate location of known major tile lines is shown along with the location and identification of the study sites in figure 1.

A total of 102 wells were installed at 38 welldrilling locations at seven study sites. Observation wells were installed using a nested approach at each location. A nest of wells consists of two or more 2-in. diameter wells with poylvinyl chloride casings drilled within close proximity to each other. Wells within each nest were screened at different intervals to provide information from various depths at approximately the same geographic location. The boreholes were drilled using 3.5-in. diameter, solid-stem augers. The augers were used to construct a borehole that, because of the cohesiveness of the materials penetrated, would not collapse upon removal of the augers. The observation well was constructed by lowering an assembly consisting of a 2.5 - $\mathrm{ft}$ length of 0.020 -in. slotted well screen and attached riser into the borehole. The borehole adjacent to and approximately $1 \mathrm{ft}$ above the well screen was packed with washed sand of appropriate size to match the screen slot size. The remainder of the borehole was backfilled with bentonite pellets to prevent vertical hydraulic interconnection of the materials penetrated and to prevent the infiltration of surface runoff along the outside of the well casing. Wells were developed by repeated bailings.

Locations for installing well nests were selected to be at the edges of fields or topographically downslope of the various selected fields where possible. Typically, one well nest was located upgradient of other well nests at a site to provide information on lateral hydraulic-head gradients. Informative logs of material encountered while drilling the deepest well at each well-nest location are given in table 2 at the back of this report. The top of each well was surveyed for vertical control by differential leveling from established bench marks. Water levels were measured from 
the top of each well by calibrated steel tape or electrical line.

Figure 2 is a hydrograph of water levels measured in well WC-16-16 at a depth of about $16 \mathrm{ft}$ below land surface and is typical of the seasonal water-level fluctuations observed in most observation wells within the watershed during the time of study. In general, seasonal water levels in most observation wells fluctuated in response to wet and dry periods. Water levels were highest in many wells during the spring of 1991 shortly after well nests WC-1 through WC-25 were drilled. Within a month of well construction, a steady decline of water levels occurred until November 1991. The lowest water levels in many wells were measured during October 1991. During the late summer and fall of 1991, water levels declined below the bottom of the screened interval in many wells less than about $6 \mathrm{ft}$ deep. Water levels rose from November 1991 to early 1992 and fluctuated for the remainder of 1992 between the two extremes set in May and October of 1991. A general rise in water levels began in March 1993, and water levels remained high throughout the summer of 1993 in response to above-normal rainfall during this time. Water levels in some wells during 1993 were higher than water levels measured in May 1991.

A description of the geologic materials, waterlevel fluctuations, and estimated direction of lateral ground-water flow at each of the seven study sites follows. A description of the vertical component of flow at each well nest is not possible at this time because the purging and collection of water-quality

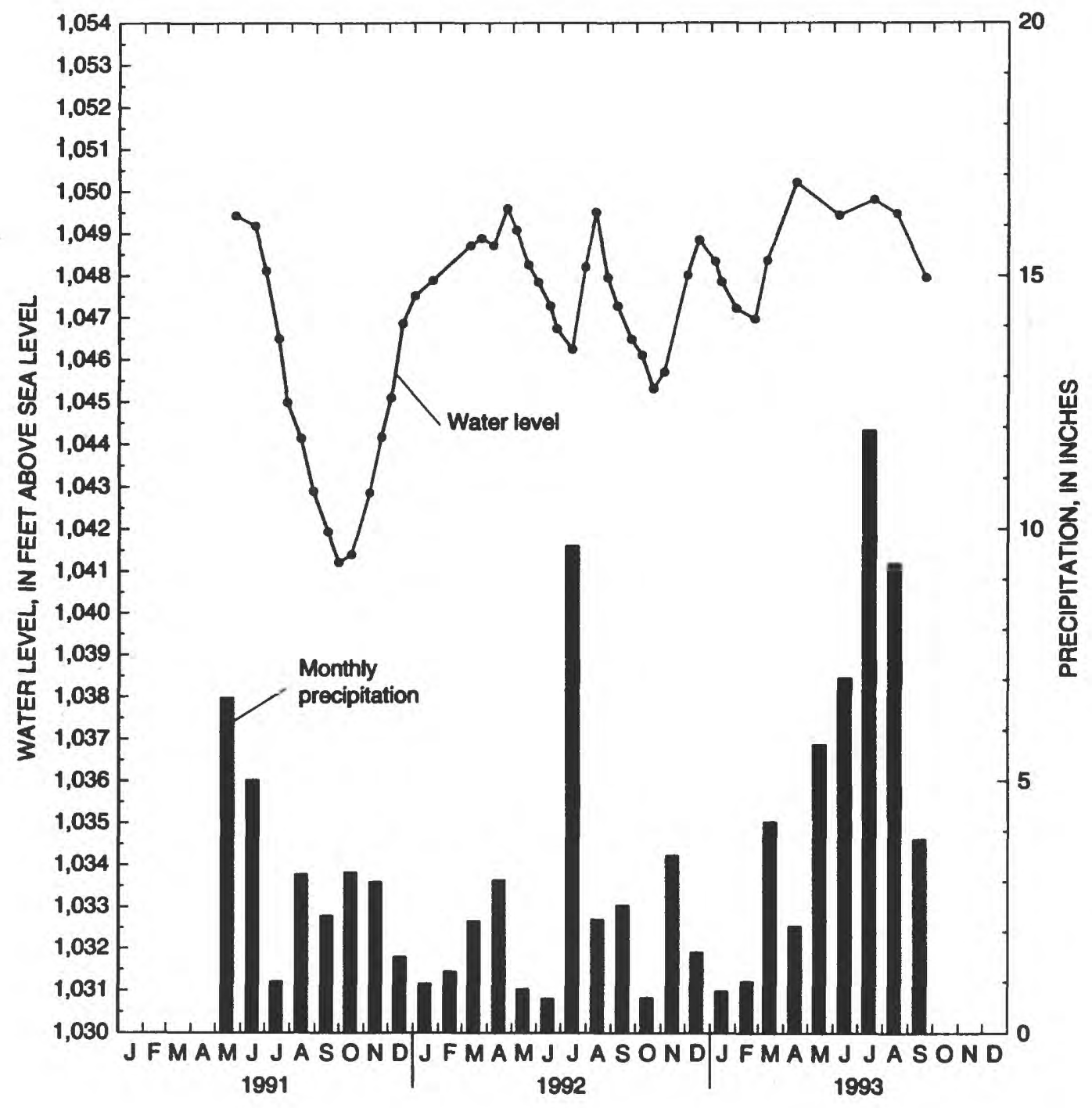

Figure 2. Hydrograph of water levels in well WC-16-16, May 1991 through September 1993. 
samples from the wells on a regular basis can result in water levels that have not reached equilibrium with the surrounding earth materials. The shallowest well that contained water was used to construct potentiometric-surface maps of water levels at the study sites for selected dates. The maps coincide with times when water levels were between observed 1991-93 maximums and minimums and are believed to be representative of the general patterns of ground-water flow. Data on the materials encountered during drilling the deepest borehole at each well nest (table 2), well construction (table 3 ), and measured water levels from May 1991 through September 1993 (table 4) are listed at the back of this report.

\section{Site 110}

Site 110 is located in the southeastern part of sec. 25 , T. 83 N., R. 25 W. (fig. 1). Surface drainage from central parts of the site is generally towards the east. Five nests of observation wells, WC-5, WC-7, WC-9, WC-10, and WC-11 (fig. 3) were installed in 1991 for a total of 15 wells at the site. The deepest well is located at WC-7 and is about $22 \mathrm{ft}$ deep.

Unoxidized glacial material was reached at depths from 9.5 to $16 \mathrm{ft}$ below land surface at the well nests. The top of a sandy zone that ranged in depth from 2.5 to $4 \mathrm{ft}$ and in thickness from 3 to $10 \mathrm{ft}$ was encountered at each well nest.

Water levels measured during the study period at this study site ranged from slightly less than $1,024 \mathrm{ft}$ above sea level to about $1,038.5 \mathrm{ft}$. The maximum water level measured occurred during May 1991, and the lowest water level occurred during October 1991. The largest measured water-level fluctuation, $9.91 \mathrm{ft}$, occurred in the well about $14 \mathrm{ft}$ deep at well nest WC-7. A potentiometric-surface map of water levels at the site on June 1, 1992 (fig. 3), shows the general direction of ground-water flow (from high to low hydraulic head and perpendicular to potentiometric contours) at the site to be toward a large drainage tile line that lies between well nests WC-7 and WC-9. Flow in the tile is towards the east. The hydraulic-head gradient towards the tile indicates that the tile is a line of lateral ground-water discharge. Well nests WC-7 and WC-9 are downgradient on ground-water flow paths beneath site 110. Ground-water flow paths extend beyond the north and west boundaries of site 110 . Water levels and water quality at well nests WC -10 and WC-11, because they are located on the western boundary of site 110 , probably are affected by water originating beyond site 110 .

\section{Site 120}

Study site 120 is located in the southeastern part of sec. 29, T. 83 N., R. 24 W. (fig. 1) and slopes gradually from the northern part of the field to Walnut Creek, which forms the southern boundary of the study site.

Six nests of observation wells were installed-WC-15, WC-17, and WC-19 in the spring of 1991 and WC-29, WC-30, and WC-31 in the spring of 1992 (fig. 4). A total of 19 wells have been constructed at this study site; the deepest well, at WC-29, is about $18 \mathrm{ft}$ below land surface.

The depth to the unoxidized material is between 9 and $13 \mathrm{ft}$ below land surface. A zone of sand or sandy clay was penetrated at each of the six well nests. The zone was encountered between 2 and $11 \mathrm{ft}$ below land surface and was from 1.5 to $8.0 \mathrm{ft}$ thick.

Water levels at the site ranged from about $995 \mathrm{ft}$ above sea level to nearly $1,018 \mathrm{ft}$. The maximum water level measured during the study period was during April 1993, and the minimum was during July 1992. The largest measured water-level fluctuation, $5.75 \mathrm{ft}$, occurred in a well about $9 \mathrm{ft}$ deep at well nest WC-17. Water levels in the shallowest wells, 4 to $6 \mathrm{ft}$ deep, were below the bottom of the well screen at times during 1991 and 1992. The direction of groundwater movement on June 4, 1992 (fig. 4), followed the southerly topographic slope of the site towards Walnut Creek. Lateral ground-water flow towards Walnut Creek from the adjacent site 160 indicates that Walnut Creek is a line of ground-water discharge for both sites. Well nests WC-15, WC-17, and WC-19 along Walnut Creek are located downgradient on groundwater flow paths. The length of the flow paths north of well nests WC-29, WC-30, and WC-31 and whether the flow paths extend beyond the management practice in place on site 120 have not been determined.

\section{Site 130}

Site 130 is located in the southern part of sec. 28 , T. 83 N., R. 24 W. (fig. 1). Walnut Creek is adjacent to the southwestern part of the field that is being studied. The field is affected by drainage tile as evidenced by a field drainage tile (not shown) discharging to Walnut Creek between well nests WC-2 and WC-3 (fig. 5). The extent and location of the tile is not known. Four 


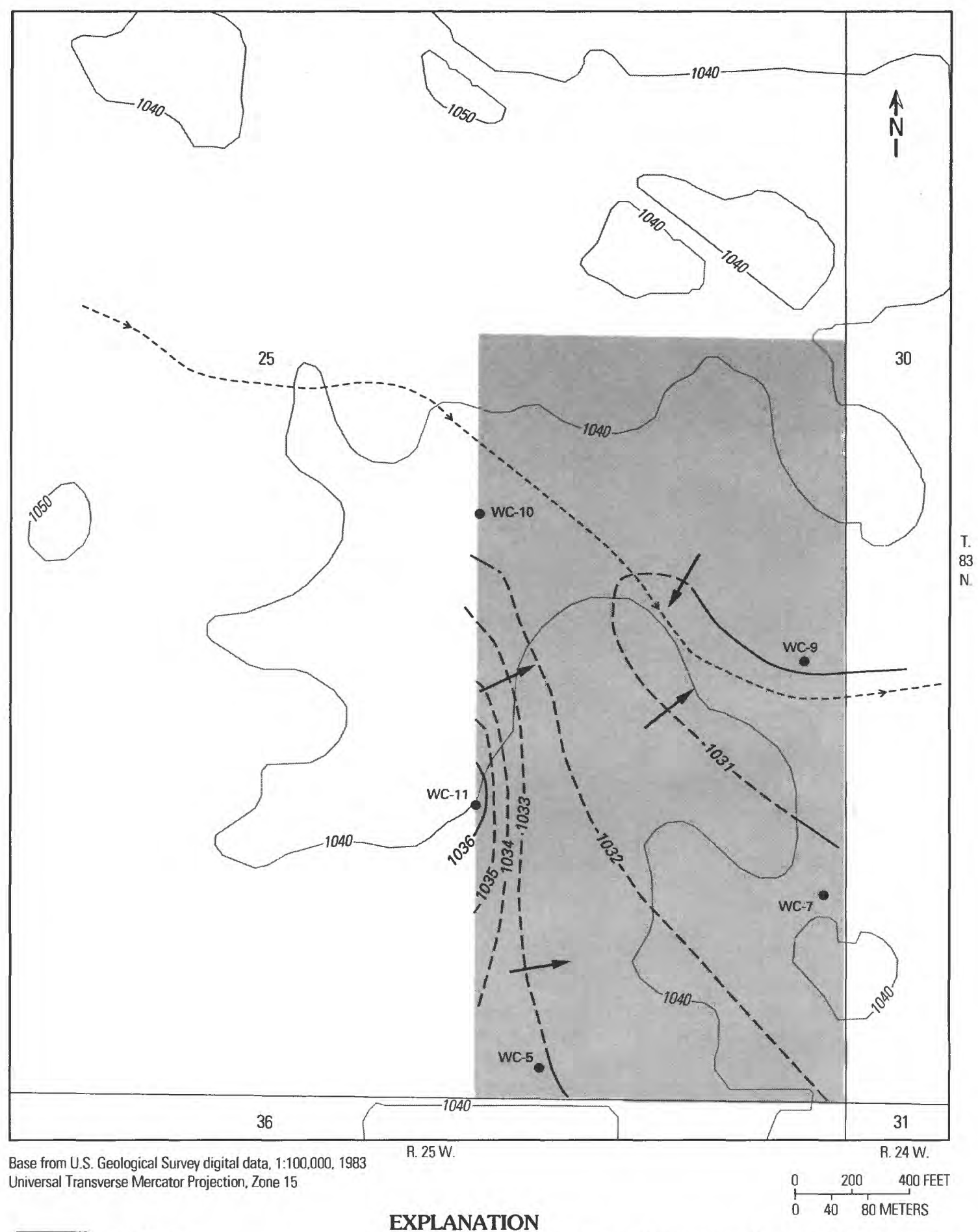

\section{Study site}

-1031- - Potentiometric contour-Shows altitude at which water levels would have stood in tightly cased wells. Dashed where approximately located. Contour interval is 1 foot. Datum is sea level

-1040 - Topographic contour-Shows altitude of land surface. Contour interval is 10 feet. Datum is sea level

Figure 3. Potentiometric surface, site 110, June 1, 1992. 


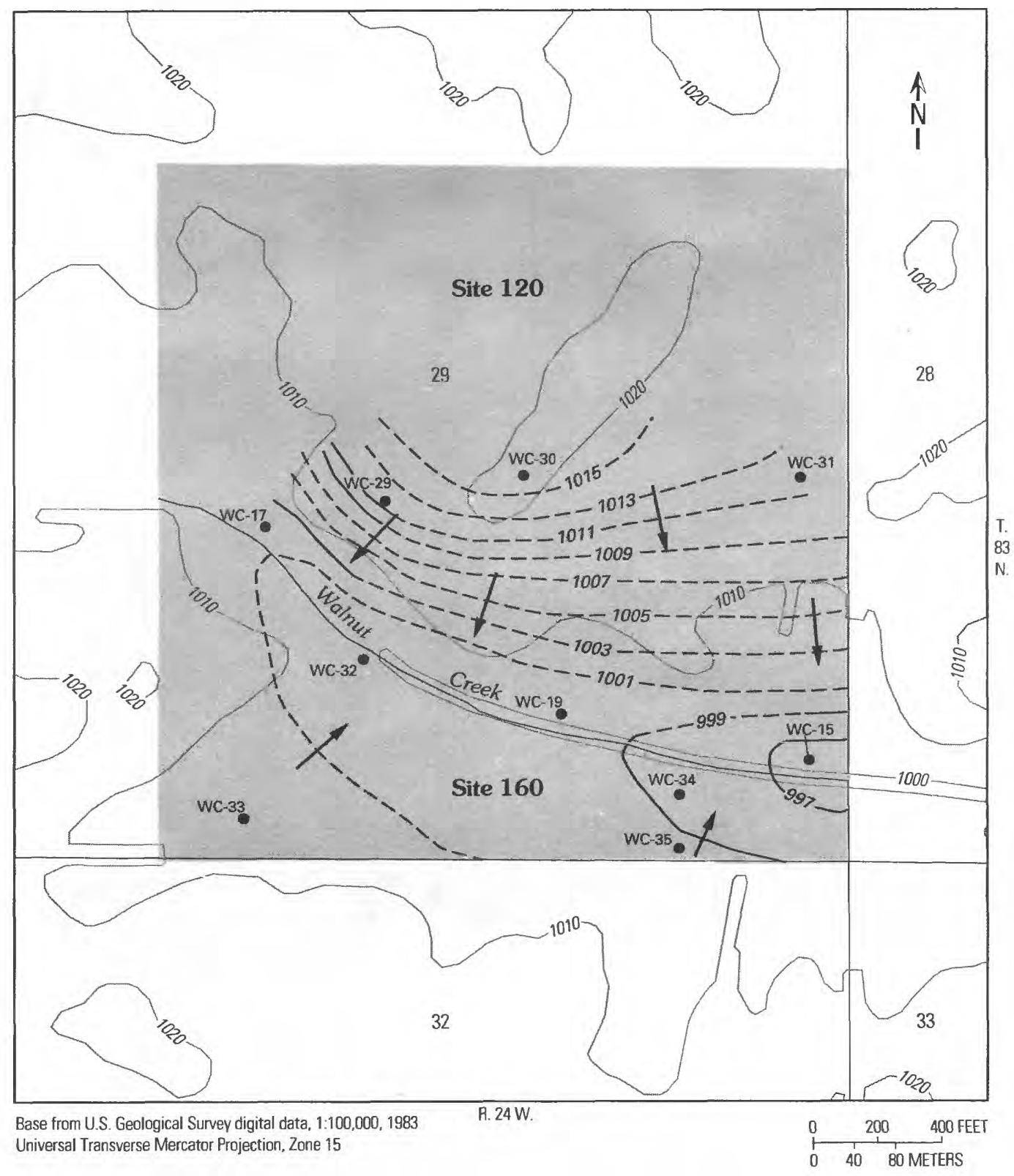

\section{EXPLANATION}

Study site

-1015- - Potentiometric contour-Shows altitude at which water levels would have stood in tightly cased wells. Dashed where approximately located. Contour interval is 2 feet. Datum is sea level

-1020_- Topographic contour-Shows altitude of land surface. Contour interval is 10 feet. Datum is sea level

$\longrightarrow$ Approximate direction of ground-water flow

- WC-19 Well nest and local number

Figure 4. Potentiometric surface, sites 120 and 160, June 4, 1992. 


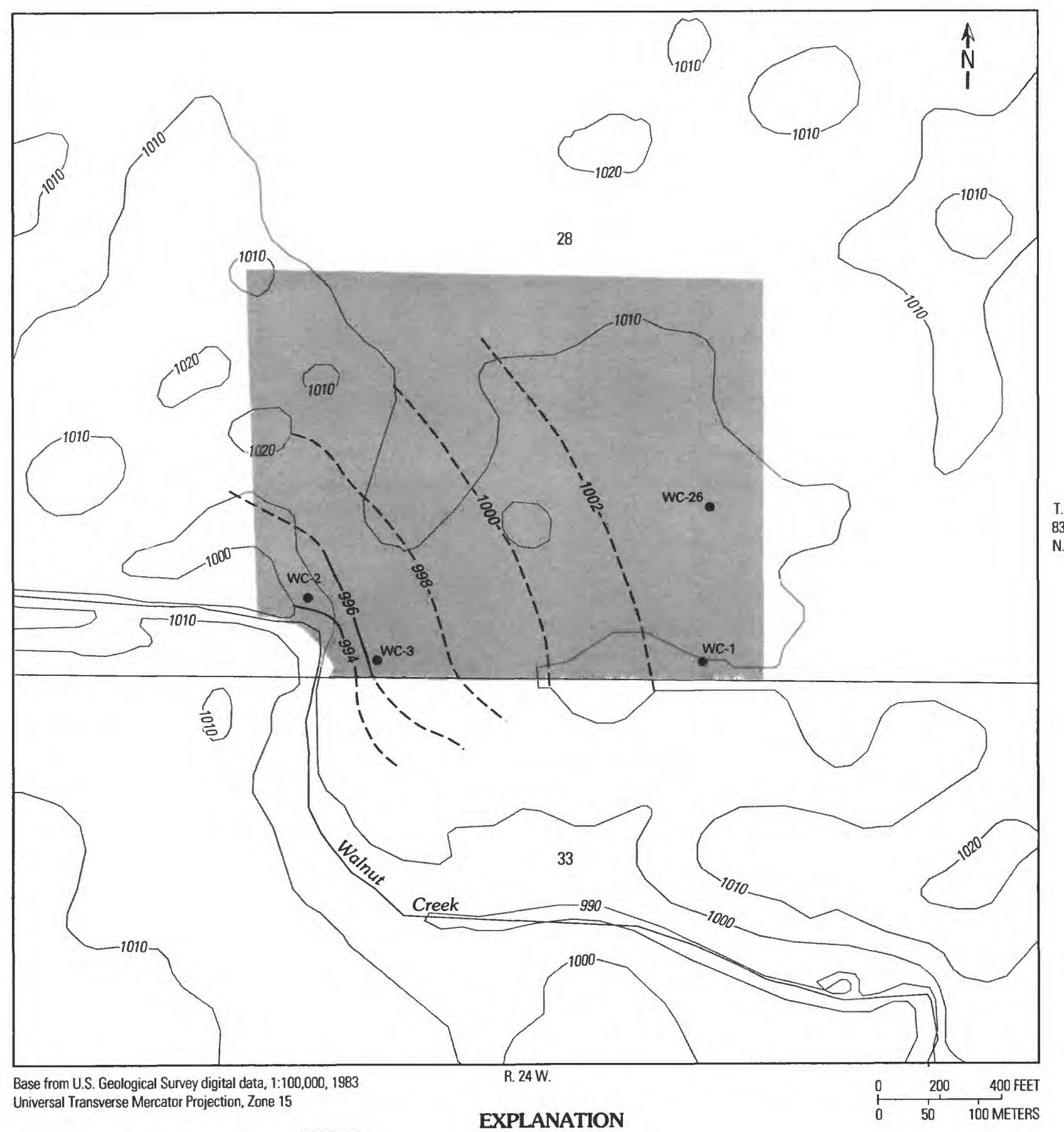

Study site

-998- - Potentiometric contour-Shows altitude at which water levels would have stood in tightly cased wells. Dashed where approximately located. Contour interval is 2 feet. Datum is sea level

-1010- Topographic contour-Shows altitude of land surface. Contour interval is 10 feet. Datum is sea level

- wC-26 Well nest and local number

Figure 5. Potentiometric surface, site 130, June 4, 1992. 
nests of observation wells were installed; well nests WC-1, WC-2, and WC-3 in the spring of 1991 and well nest WC-26 in the spring of 1992. A total of 13 wells have been constructed at this study site; the deepest, at well nest WC-2, is about $21 \mathrm{ft}$ below land surface.

The depth to the top of the unoxidized material at the well nests is between 7 and $13 \mathrm{ft}$ below land surface. A sandy zone was present at well nests WC $-1, W C-3$, and WC -26 . The sandy zone was not as evident at well nest WC-2, and the transition from oxidized to unoxidized material was more gradual at this well nest.

Water levels measured during the study period at this study site ranged from less than $990 \mathrm{ft}$ above sea level to more than $1,007 \mathrm{ft}$. The highest water level, $1,007.48 \mathrm{ft}$, occurred in the 16 - $\mathrm{ft}$ deep well at well nest WC-26 on July 15, 1993. Water levels in the two deepest wells at well nest WC-2, 14 and $21 \mathrm{ft}$ below land surface, were lower than $990 \mathrm{ft}$ above sea level but exhibited a pattern of fluctuation, particularly during 1992, that indicates the wells were recovering from water-sample collection and were not fully recovered prior to the next water-level measurement. Water levels in these wells are not considered static water levels. However, these slower recovery rates compared to shallower wells at this well nest indicate that the deeper, unoxidized material has a smaller hydraulic conductivity than the shallower, oxidized material.

The shallowest wells at each well nest were completed at depths between about 4 and $6 \mathrm{ft}$ below land surface. Water levels declined below the screened interval of these wells at times during 1991 and 1992. The maximum measured static water-level fluctuation, $7.49 \mathrm{ft}$, occurred in a well about $9 \mathrm{ft}$ deep at well nest WC-1.

Ground-water movement at site 130 on June 4, 1992 (fig. 5), was towards the southwest, towards Walnut Creek. Well nests WC-2 and WC -3 are downgradient on ground-water flow paths beneath site 130 . Well nest WC -1 is probably downgradient of the eastern parts of site 130 . The extent of the ground-water flow system draining towards Walnut Creek from this site has not been determined.

\section{Site 140}

This study site is located in the eastern part of sec. 2 , T. 82 N., R. 24 W. (fig.1). A ravine leading to
Walnut Creek begins on the northern edge of the study site. Two nests of observation wells were installed during the spring of 1992-WC-27 and WC-28 (fig. 6). The deepest well at this study site is about $30 \mathrm{ft}$ deep at well nest WC-27.

Unoxidized glacial material was reached at 28 and $14 \mathrm{ft}$ below land surface at nests WC-27 and WC-28, respectively. About $2.5 \mathrm{ft}$ of sandy material was penetrated at a depth of $5 \mathrm{ft}$ at well nest WC-28. No substantial amounts of sand were found at nest WC-27.

Water levels measured during the study period ranged from less than $939 \mathrm{ft}$ above sea level to more than $979 \mathrm{ft}$. The highest water level measured at this site was during April 1993, and the lowest was during October 1992. There was an 18.68-ft water-level fluctuation, the maximum measured for this site, in the well about $30 \mathrm{ft}$ deep at nest WC-27. The relatively steep topographic relief at site 140 has a direct effect on the direction of ground-water flow. Flow is towards the ravine, which probably serves as an area of lateral ground-water discharge (fig. 6). Well nest WC-27 is downgradient on a ground-water flow path beneath site 140. The extent of the flow paths beyond nest WC-28 is not known.

\section{Site 160}

Study site 160 is located in the southeastern part of sec. 29, T. 83 N., R. 24 W. (fig. 1). Walnut Creek flows along the northern boundary of the study site. A total of 11 wells at four well nests, WC-32, WC-33, WC-34, and WC-35 (fig. 4), were installed during the spring of 1992. The deepest well drilled at this site is about $30 \mathrm{ft}$ below land surface at nest WC-34.

The depth to the unoxidized material at the well nests ranged from 7.5 to $10 \mathrm{ft}$ below land surface. A sandy zone was reached at each of the four nests at depths of 1 to $11.5 \mathrm{ft}$ below land surface. Thicknesses of the sandy material ranged from 2 to $6.5 \mathrm{ft}$.

Water levels measured during the study period at this site ranged from about 996 to $1,005 \mathrm{ft}$ above sea level. The highest water level measured at the study site occurred at nest WC-33 during April 1993. The lowest water level was at well nest WC-34 during October 1992. The largest measured water-level fluctuation, $4.34 \mathrm{ft}$, occurred in a well $6 \mathrm{ft}$ deep at nest WC-33. Lateral ground-water flow at site 160 on June 4, 1992, was northeasterly towards Walnut Creek (fig. 4). Well nests WC-32 and WC-34 are down- 


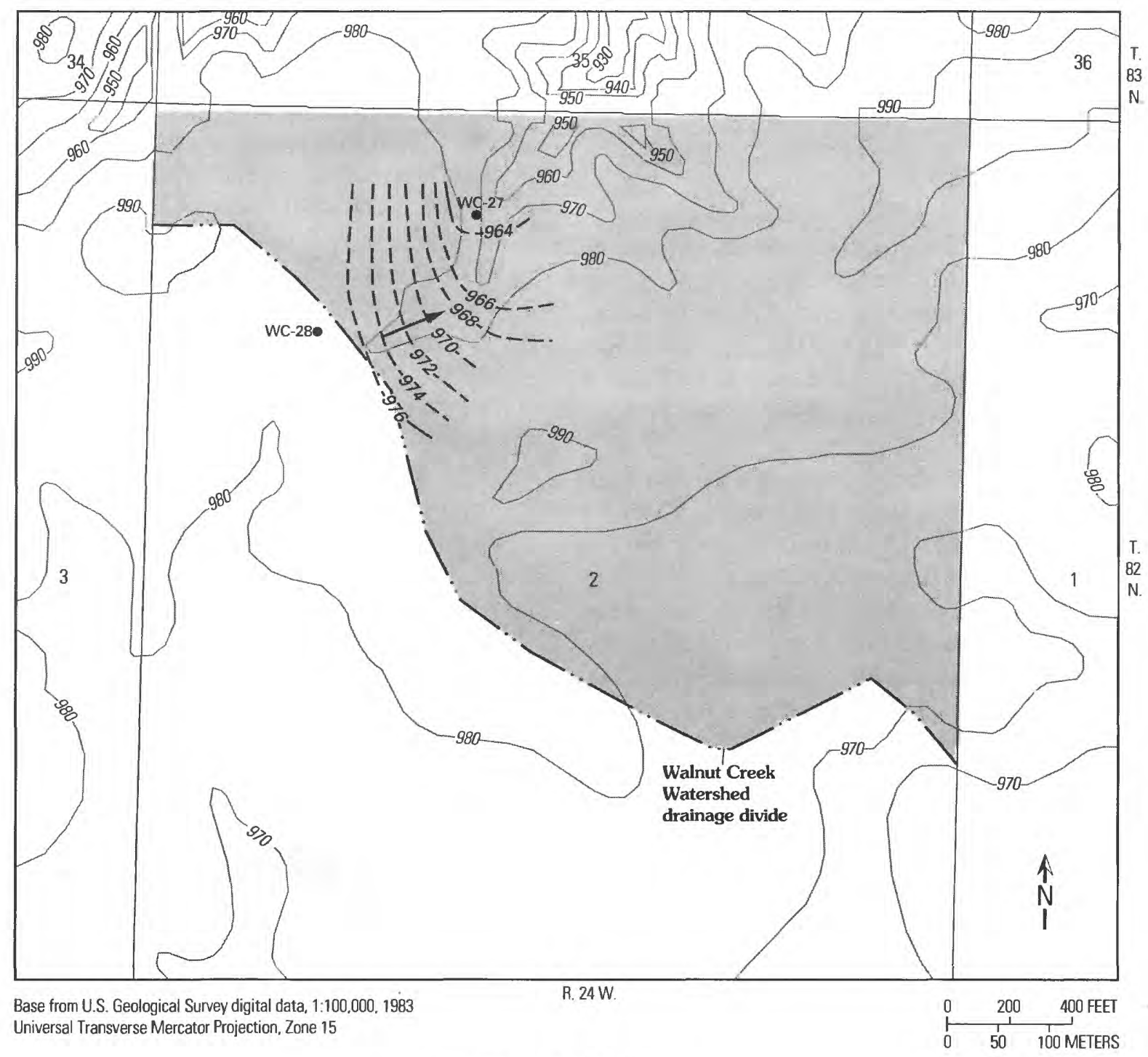

EXPLANATION

Study site

-972- - Potentiometric contour-Shows altitude at which water levels would have stood in tightly cased wells.

Dashed where approximately located. Contour interval is 2 feet. Datum is sea level

- 980 - Topographic contour-Shows altitude of land surface. Contour interval is 10 feet. Datum is sea level

$\longrightarrow$ Approximate direction of ground-water flow

- WC-28 Well nest and local number

Figure 6. Potentiometric surfice, site 140, June 4, 1992. 
gradient on ground-water flow paths from beneath site 160 . Well nests WC-33 and WC-35 are located on the upgradient boundary of the study site and probably are affected by lateral ground-water flow from offsite areas to the south.

\section{Site 170}

Site 170 is located in the eastern part of sec. 24 , T. 8 N., R. 25 W. (fig. 1). Surface drainage is generally towards the east. Three nests of observation wells, WC-36, WC-37, and WC-38 (fig. 7), were installed during the spring of 1992. The deepest well, about $24 \mathrm{ft}$ below land surface, is located at well nest WC-36.

Unoxidized glacial materials were reached at depths of 9.5 to $17 \mathrm{ft}$ below land surface. About $4 \mathrm{ft}$ of sand was penetrated at each well nest, and the top of the sand ranged in depth from 2.5 to $4 \mathrm{ft}$.

Water levels measured at this site during the period of study ranged from less than 1,023 to more than $1,040 \mathrm{ft}$ above sea level. The highest measured water level was at nest WC-36 during July 1993, and the lowest water level was measured at nest WC-38 during October 1992. The well about $24 \mathrm{ft}$ deep at nest WC-30 had the greatest measured water-level fluctuation, $5.95 \mathrm{ft}$.

Well nest WC-36 (fig. 7) is located near a topographic high on the south boundary of the study site, probably near a ground-water divide. Well nest WC-37 (fig. 7) is located on the west-central boundary of the study site, and water levels are affected by offsite areas to the west. Well nests WC-37 and WC-38 are located near tile lines. The potentiometric surface at site 170 has not been mapped because of insufficient well control to define the direction of flow throughout the site. However, it is hypothesized that ground-water flow is from the northern and southern boundary areas towards the east-central parts of the study site.

\section{Site 220}

This study site is located in the northern halves of sec. 36 , T. 83 N., R. 25 W., and sec. 31 , T. 83 N., R. 24 W. (fig. 1). Interior areas of the study site are drained by a network of drainage tiles that connect to a large drainage tile that discharges to a ditch and discharges to Walnut Creek northeast of site 220. The site contains a small drainage basin comprised of a variety of management systems. Fifteen nests of observation wells were installed in 1991 throughout the drainage basin (fig. 8).

The depth to the unoxidized glacial material was determined at 12 of the 15 well nests. Depths to the unoxidized zone ranged from $10.5 \mathrm{ft}$ at nest $\mathrm{WC}-21$ to $20 \mathrm{ft}$ at nest WC-13. Sandy material was encountered at each of the well nests. The top of the sandy zone ranged in depth from 2.5 to $12.5 \mathrm{ft}$ at nests $\mathrm{WC}-12$ and WC-23, respectively. Thicknesses of the sandy zone ranged from about 1 to $6.5 \mathrm{ft}$. Well nests $\mathrm{WC}-18$ and WC -25 consist of only one well at each location because saturated sand reached at a depth of about $9 \mathrm{ft}$ prevented the borehole from remaining open to allow installation of a deeper well.

Water levels measured at this site during the study period ranged from less than 1,020 to more than $1,051 \mathrm{ft}$ above sea level. The maximum water level measured at the site was at nest WC-16 during May 1991. The lowest water level occurred during October 1991 at well nest WC-14. There was a 12.83-ft water-level fluctuation, the maximum measured during the study at this site, at nest WC-24. The generalized flow of ground water in the eastern half of study site 220 was towards a large drainage tile line that discharges to a ditch that forms part of the headwaters of Walnut Creek at the extreme northeast corner of the site (fig. 8). The pattern of potentiometric contours indicates that the drainage tile is a line of lateral discharge in this part of the study site. The western half of the study site is a hummocky, pothole terrain, and the location of all the small tile lines draining the area are not known. This has apparently resulted in a complicated ground-water flow system that generally can be described as flow from the higher parts of hummocks towards the potholes where discharge to drainage tiles, if present, occurs. The extent of the ground-water drainage area beyond site 220 has not been determined. Most well nests within the study site probably are affected by multiple management systems in use within the site 220 area.

\section{SUMMARY}

Ground-water data were collected from May 1991 through September 1993 from observation wells installed in the Walnut Creek Watershed near Ames, Iowa, as part of the Iowa Management Systems Evaluation Area effort. The purpose of the data collection was to determine the direction of ground- 


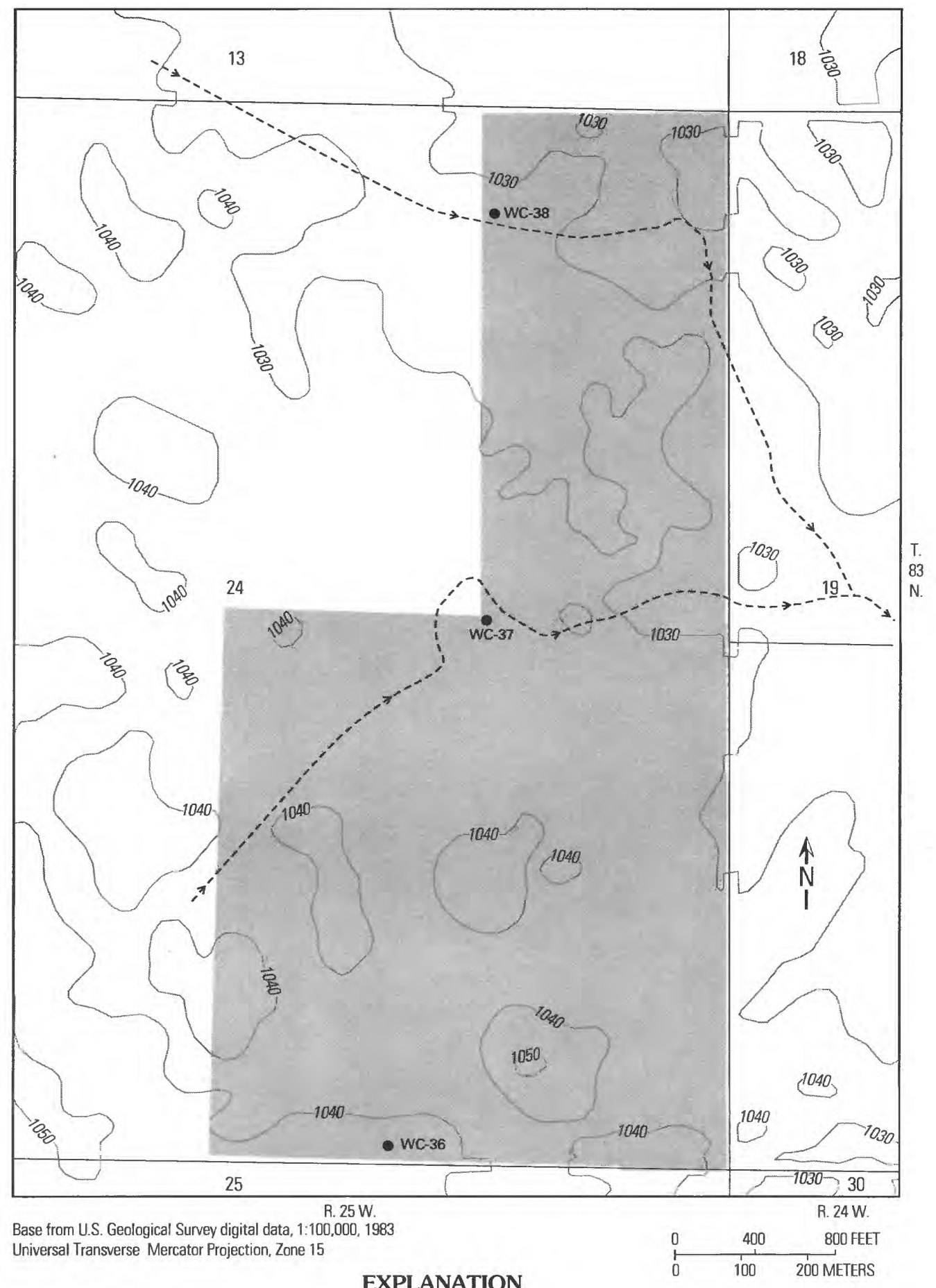

EXPLANATION

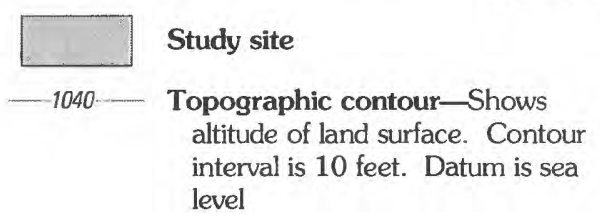

$\rightarrow---\rightarrow-$ Approximate location of drainage

tile line-Arrow shows direction of flow

- wC-36 Well nest and local number

Figure 7. Topography at site 170. 


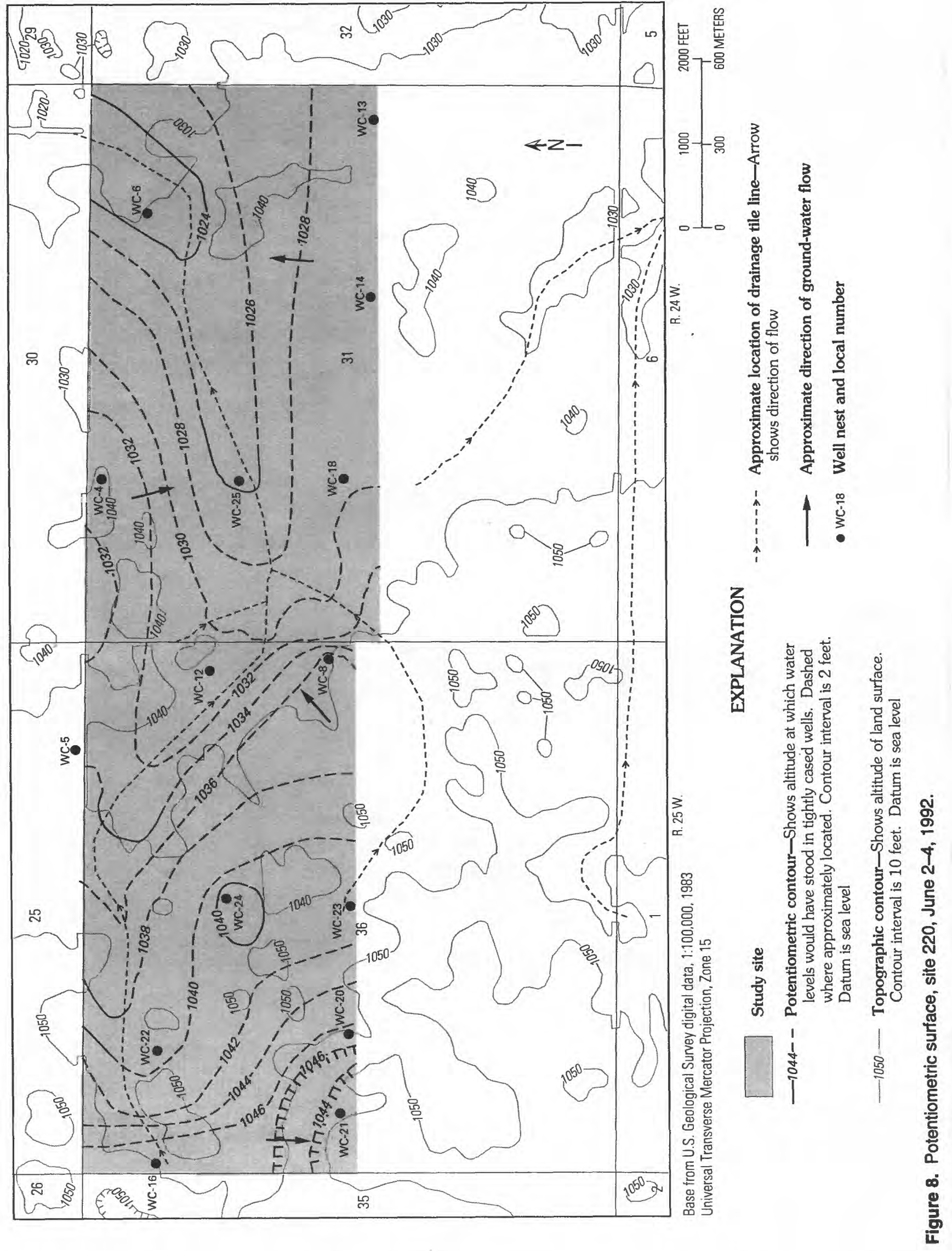


water flow at selected study sites where a variety of agricultural management practices are being studied.

Glacial deposits of Wisconsinan and pre-

Illinoian age underly the watershed. These non-aquifer materials are more than $200 \mathrm{ft}$ thick in some areas of the watershed and overly bedrock of Mississippian or Pennsylvanian age. The upper glacial deposits appear to be supraglacial tills rather than basal tills, based on particle-size analysis, and occur in both oxidized and unoxidized conditions.

Water levels were measured in 102 wells from 38 locations at 7 study sites in the watershed. Water levels fluctuated in response to local climatic conditions and ranged from at or near the land surface to more than $30 \mathrm{ft}$ below land surface. In general, ground water flowed towards Walnut Creek or large drainage tiles. Potentiometric maps at the selected study sites can be used to determine which locations might be affected by agricultural management practices in place at each site.

\section{REFERENCES}

Hallberg, G.R., 1980, Pleistocene stratigraphy in eastcentral Iowa: Iowa City, Iowa Geological Survey Technical Information Series No. 10, 168 p.

Kemmis, T.J., Hallberg, G.R., and Lutenegger, A.J., 1981, Depositional environments of glacial sediments and landforms on the Des Moines Lobe, Iowa: Iowa City, Iowa Geological Survey Guidebook Series No. 6, $133 \mathrm{p}$.

Leavesley, G.H., Lichty, R.W., Troutman, B.M., and Saindon, L.G., 1983, Precipitation-runoff modeling system-User's manual: U.S. Geological Survey Water-Resources Investigations Report 83-4238, 207 p. 


\section{SUPPLEMENTAL HYDROLOGIC INFORMATION}

Table 2. Descriptive logs of selected boreholes drilled in the Walnut Creek Watershed, Boone and Story Counties, lowa

Local number: WC-1-14

Location: T. 83 N., R. 24W., sec. 28 , SW1/4

Description
Date: $2 / 25 / 91$

Altitude of land surface: 1,008 feet

Depth interval (feet)

Topsoil, black, organic, frozen $0-1.0$

Topsoil, black, clayey, cohesive

$1.0-3.0$

Clay, medium-brown, oxidized, sandy, cohesive

$3.0-7.0$

Clay, brown to gray, very sandy, mottled, appears fractured, water saturated.

$7.0-7.5$

Clay, as above, less sand, very cohesive

$7.5-10.5$

Clay, medium- to dark-gray, sandy, pebbles, unoxidized, very cohesive

$10.5-15.0$

Clay, as above
Date: 2/26/91

Altitude of land surface: 998 feet
Local number: WC-2-21

Location: T. 83 N., R. 24W., sec. 28, SW1/4
Depth interval (feet)

\section{Description}

Topsoil, black, organic, frozen

Topsoil, black, organic

Soil, medium-brown, clayey, cohesive

$0-0.5$

$0.5-2.0$

Clay, mottled brown-gray, very sandy, pebbles

$2.0-5.5$

Clay, bluish-gray, wet.

Clay, blue-gray, pebbles, appears dry, very stiff

$5.5-6.0$

$6.0-8.0$

$8.0-9.0$

Clay, blue-gray grading to dark-gray with depth, pebbles, stiff, cohesive

$9.0-18.0$

Clay, dark-gray, stiff, cohesive.
Local number: WC-3-11

Location: T. 83 N., R. $24 W$. , sec. 28 , SW1/4

\section{Description}

Topsoil, black, organic

Sand, medium-brown, clayey, cohesive, oxidized

Clay, medium-brown to gray, mottled, sandy, pebbles, cohesive, oxidized

Clay, medium-gray, dense, slightly sandy, some pebbles, cohesive.
Date: 2/26/91

Altitude of land surface: 1,000 feet

Depth interval (feet)

$$
\begin{aligned}
& 0-1.5 \\
& 1.5-6.0 \\
& 6.0-7.0 \\
& 7.0-12.5
\end{aligned}
$$


Table 2. Descriptive logs of selected boreholes drilled in the Walnut Creek Watershed, Boone and Story Counties, lowa-Continued

Local number: WC-4-16

Date: 2/26/91

Location: T. 83N., R. 24W., sec. 31, NW1/4

Altitude of land surface: 1,037 feet

\section{Description}

Depth interval (feet)

Topsoil, black, organic

$0-4.0$

Clay, brown to brown-gray, mottled, sandy, gravelly, cohesive

Clay, gray and brown, mottled, sand, pebbles, appears fractured

Clay, dark-gray, dense, cohesive, less sand and pebbles than above.

$11.5-17.5$

Local number: WC-5-14

Location: T. 83 N., R. 25W., sec. 25, SE1/4

\section{Description}

Topsoil, black, organic, frozen

Topsoil, black, organic

Clay, brown-gray, mottled, sandy, pebbles, cohesive, oxidized, becomes more gray with depth

Clay, gray, sandy, pebbles, less sand than above, cohesive
Date: $2 / 27 / 91$

Altitude of land surface: 1,037 feet

Depth interval (feet)

$0-1.0$

$1.0-2.5$

$2.5-9.0$

$9.0-15.0$

\section{Description}

Depth interval (feet)

Topsoil, black, organic, frozen .

$0-0.5$

Topsoil, black, organic

Clay, brown to slightly gray, mottled, sandy, pebbles, cohesive, oxidized

Clay, brown to gray, very sandy, poorly sorted sand, fine to coarse, pebbles up to 1 -inch diameter

Clay, dark-gray, sandy, gravelly, cohesive at the bottom 
Table 2. Descriptive logs of selected boreholes drilled in the Walnut Creek Watershed, Boone and Story Counties, lowa-Continued

Local number: WC-7-21

Locatlon: T. 83N., R. 25W., sec. 25, SE1/4
Date: $3 / 26 / 91$

Altitude of land surince: 1,037 feet

Depth Intervr' (feet)

\section{Descriptlon}

Topsoil, black, sandy, organic

Clay, light-gray to brown, sandy, cohesive, oxidized.

Clay, as above, but increasing sand with depth.

Clay, as above, but less sand, oxidized

Clay, brown-gray, mottled, stiff, cohesive, pebbles, less oxidation and sand.

Clay, dark-gray, cohesive, very gravelly, sandy

Clay, as above, but less gravel

$$
\begin{array}{r}
0-3.0 \\
3.0-8.0 \\
8.0-11.0 \\
11.0-13.0 \\
13.0-16.0 \\
16.0-18.0 \\
18.0-22.5
\end{array}
$$

Topsoil, black, clayey, organic

$$
\begin{array}{r}
0-3.0 \\
3.0-4.0 \\
4.0-8.0 \\
8.0-14.0 \\
14.0-15.5 \\
15.5-20.5
\end{array}
$$

Clay, medium-brown, very sandy and gravelly

Clay, medium-brown, slight mottling, less sand

Clay, gray-brown, mottled, sandy, gravelly

Clay, blue-gray, slightly sandy, slightly pebbly, cohesive

Local number: WC-9-13

Locatlon: T. 83N., R. 25W., sec. 25, SE1/4

Description
Date: 4/01/91

Aititude of land surnince: 1,035 feet

Depth Intervr' (feet)

Topsoil, black, clayey, sandy, organic $0-2.5$

Clay, gray-brown, sandy, oxidized $2.5-4.0$

Clay, olive-brown, very sandy, sand grain size increases with depth

$4.0-7.0$

Clay, gray-brown, mottled, sandy

$7.0-9.5$

Clay, dark-gray, sandy, cohesive
$9.5-14.5$ 
Table 2. Descriptive logs of selected boreholes drilled in the Walnut Creek Watershed, Boone and Story Counties, lowa-Continued

Local number: WC-10-17

Location: T. 83 N., R. 25W., sec. 25, SE1/4

Description
Date: 4/02/91

Altitude of land surface: 1,036 feet

Depth interval (feet)

Topsoil, black, clayey, organic

$0-3.5$

Clay, gray olive-brown, sandy, oxidized

$3.5-6.0$

Clay, brown-gray, mottled, sandy, oxidized, appears dry.

$6.0-8.0$

Clay, rusty-brown, no mottling, wet at 9.0 feet, sandy

$8.0-11.0$

Clay, brown-gray, mottled, sandy

$11.0-12.0$

Clay, dark-gray, sandy, pebbles, cohesive

$12.0-18.5$

Local number: WC-11-15

Location: T. 83N., R. 25W., sec. 25, SE1/4

Descriptlon

Topsoil, black, clayey, organic

Clay, olive-gray, sandy

Clay, rusty-brown, very sandy, becoming more cohesive with depth, water entering the hole at 4.0 feet

Clay, rusty-brown, streaks of gray, very sandy, gravelly, less water

Clay, brown-gray, mottled, very sandy, pebbles, stiff in places

Clay, dark-gray, sandy, pebbles
Date: 4/02/91

Altitude of land surface: 1,0$\urcorner 9$ feet

Depth Interval (feet)

$$
\begin{aligned}
& 0-3.0 \\
& 3.0-5.5 \\
& 5.5-9.0 \\
& 9.0-10.5 \\
& 10.5-12.0 \\
& 12.0-16.5
\end{aligned}
$$

\section{Local number: WC-12-16}

Location: T. 83N., R. 25W., sec. 36, NE1/4

Date: 4/02/91

Altitude of land surface: 1,035 feet

\section{Description}

\section{Depth interval (feet)}

Topsoil, black, clayey, organic

$0-2.5$
$2.5-4.5$
$4.5-6.5$
$6.5-9.0$
$9.0-10.5$
$10.5-12.0$
$12.0-17.5$

Clay, dark gray-brown, sandy.

Clay, olive-gray, sandy, oxidized.

Clay, rusty-brown, sandy

Clay, rusty-brown with gray streaks, sandy

Clay, as above, stiffer with increasing gray clay content with depth

$12.0-17.5$ 
Table 2. Descriptive logs of selected boreholes drilled in the Walnut Creek Watershed, Boone and Story Counties, lowa-Continued

Local number: WC-13-24

Location: T. 83N., R. 24W., sec. 31, NE1/4

Description

Topsoil, black, organic

Clay, olive brown-gray

Clay, olive-gray, sandy, light-gray streaks at 6.5 feet

Clay, rusty-brown with light-gray streaks, sandy.

Clay, as above, tighter, shading to olive-gray with depth

Clay, dark-gray, mottled, sandy, gravel zone at 18.0 feet

Clay, dark-gray, cohesive
Date: 4/03/91

Altitude of land suriace: 1,035 feet

Depth Interval (feet)
Local number: WC-14-16

Location: T. 83N., R. 24W., sec. 31, NE1/4
Date: 4/03/91

Altitude of land surnace: 1,034 feet
Description

Topsoil, black, organic

Clay, olive-brown, sandy, oxidized

Clay, olive-gray with light-gray streaks, sandy, soft

Clay, rusty-brown with gray streaks, sandy, stiff.

Clay, olive-gray with gray streaks, sandy, pebbles, mottled, appears heavily oxidized.

Clay, dark-gray
Depth Intervr' (feet)

$$
\begin{aligned}
& 0-3.5 \\
& 3.5-6.0 \\
& 6.0-9.0 \\
& 9.0-11.0 \\
& 11.0-13.0 \\
& 13.0-17.5
\end{aligned}
$$

Local number: WC-15-16

Location: T. 83N., R. 24W., sec. 29, SE1/4
Date: 4/04/91

Altitude of land surince: 1,003 feet

Depth Interv ' ' (feet)

\section{Description}

$$
\begin{array}{r}
0-6.0 \\
6.0-6.5 \\
6.5-7.5 \\
7.5-11.0 \\
11.0-17.0
\end{array}
$$$$
\text { Soil, as above, gray-black, pebbly }
$$$$
\text { Clay, brown-gray, very sandy, pebbly, oxidized }
$$$$
\text { Clay, dark-gray }
$$

\section{Local number: WC-16-16}

Location: T. 83N., R. 25W., sec. 36, NW1/4
Date: 4/12/91

Alttude of land surn ne: 1,054 feet

\section{Depth Interv $\varepsilon^{\prime}$ (feet)}

Topsoil, dark-brown, silty, organic.

Soil, light-brown, silty, clayey, pebbly, oxidized

$0-2.0$

Clay, medium brown-gray, sandy, silty, mottled, pebbly

$2.0-5.5$

Clay, bright blue, silty, pebbly, stiff and cohesive.

$$
5.5-12.0
$$

$12.0-17.5$ 
Table 2. Descriptive logs of selected boreholes drilled in the Walnut Creek Watershed, Boone and Story Counties, lowa-Continued

Local number: WC-17-14

Location: T. 83N., R. 24W., sec. 29, SE1/4

Description
Date: 5/09/91

Altitude of land surface: 1,006 feet

Depth interval (feet)

Topsoil, brown to black, organic

$0-2.5$

Sand, dark-brown, clayey ...

$2.5-4.5$

$4.5-6.5$

Sand, medium-gray to light-brown, coarse to fine-

grained, some oxidized zones

$6.5-7.5$

$7.5-8.0$

$8.0-9.5$

$9.5-10.0$

$10.0-15.5$
Locai number: WC-18-9

Location: T. 83 N., R. 24W., sec. 31, NW1/4
Date: $5 / 09 / 91$

Aititude of land surface: 1,034 feet

\section{Depth interval (feet)}

Topsoil, black, silty, sandy

$0-2.5$

Soil, brown-black

$2.5-3.5$

Clay, dark gray-brown, silty

$3.5-4.5$

$4.5-6.0$

$6.0-7.5$

$7.5-10.0$

$10.0-12.5$
Local number: WC-19-14

Location: T. 83N., R. 24W., sec. 29, SE1/4
Date: 5/10/91

Aititude of land surface: $1,0 \mathrm{r}$ feet

Depth interval (feet)

\section{Description}

$0-2.0$
$2.0-2.5$
$2.5-4.5$
$4.5-6.5$
$6.5-7.0$
$7.0-7.5$
$7.5-8.5$
$8.5-10.0$
$10.0-12.5$
$12.5-15.0$

Topsoil, black to brown

$$
2.5
$$

Clay, brown, sandy, small sand lenses...................................................................... $2.0 \quad 2.5$

Clay, black to dark-brown, sandy ................................................................................ $2.5 \quad-\quad 4.5$

Clay, as above, with increasing clay ............................................................................. $4.5 \quad 6.5$

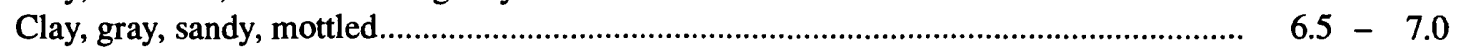

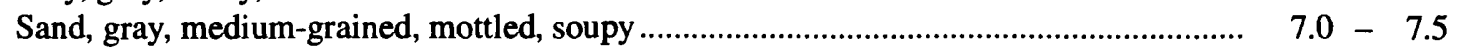

Sand, as above, with increasing clay ....................................................................... $7.5-8.5$

Clay, gray with some brown streaks, firmer drilling …................................................ $8.5-10.0$

Clay, gray, unoxidized, gravelly .......................................................................... $10.0-12.5$

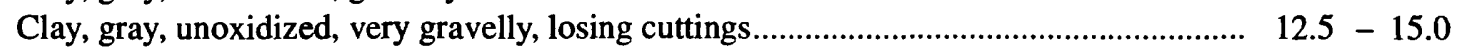


Table 2. Descriptive logs of selected boreholes drilled in the Walnut Creek Watershed, Boone and Story Counties, lowa-Continued

Local number: WC-20-16

Locatlon: T. 83N., R. 25W., sec. 36, SW1/4

Description
Date: $5 / 10 / 91$

Altitude of land surf ?e: 1,052 feet

Depth Interv $\varepsilon^{\prime}$ (feet)

Topsoil, black, organic, silty

$$
\begin{aligned}
& 0-2.5 \\
& 2.5-4.5 \\
& \text { Clay, light-brown, sandy, pebbly, sandy fractures.............................................................. } 4.5-7.5 \\
& \text { Clay, as above, firmer, sandier, less gravel................................................................ } 9.5-12.5 \\
& \text { Clay, blue-green shading to gray with depth, pebbly to gravelly....................................... } 13.0-17.5
\end{aligned}
$$$$
\text { Clay, as above, large gravel, very sandy ............................................................................. } 7.5 \text { - } 9.5
$$$$
\text { Clay, as above, no sand and gravel ................................................................................ } 12.5-13.0
$$

Local number: WC-21-14

Location: T. 83N., R. 25W., sec. 36, SW1/4
Date: 5/10/91

Altitude of land surf me: 1,046 feet

\section{Description}

Topsoil, black, organic, silty

Clay, light-gray, sandy, soft.

Clay, light-gray, sandy, mottled

Clay, as above, becoming darker.

Sand, brown, clayey, soft, some pebbles

Clay, gray, oxidized fractures, stiff

Clay, gray, unoxidized
Depth Interve" (feet)

$0-3.0$
$3.0-4.0$
$4.0-4.5$
$4.5-5.0$
$5.0-8.0$
$8.0-10.5$
$10.5-15.5$

Local number: WC-22-14

Location: T. 83N., R. 25W., sec. 36, NW1/4
Date: 5/10/91

Altitude of land surf me: 1,043 feet

\section{Description}

\section{Depth Interv\&" (feet)}

Topsoil, black, organic

$$
\begin{aligned}
& 0-2.5 \\
& 2.5-3.0 \\
& 3.0-7.5 \\
& 7.5-8.0 \\
& 8.0-9.5 \\
& 9.5-10.0
\end{aligned}
$$

Clay, light-brown, sandy sandier and pebbly with depth.

Clay, light-brown, sandy, pebbles ...

Clay, as above, with oxidized blue-gray zones

Clay, blue-gray to gray with depth, unoxidized 
Table 2. Descriptive logs of selected boreholes drilled in the Walnut Creek Watershed, Boone and Story Counties, lowa-Continued

Local number: WC-23-16

Location: T. 83N., R. 25W., sec. 36, NE1/4
Date: 5/11/91

Aititude of iand surface: 1,045 feet

Depth intervai (feet)

\section{Description}

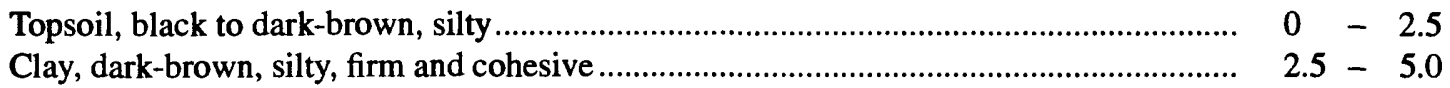

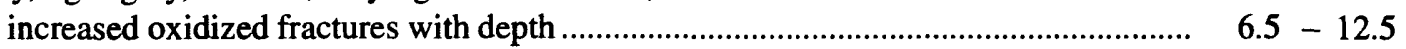

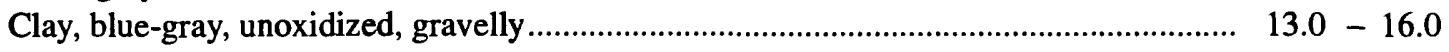

$$
\begin{aligned}
& 16.5-17.5
\end{aligned}
$$$$
\text { Clay, medium-gray, some mottling, no sand ............................................................. } \quad 5.0-6.5
$$$$
\text { Clay, light-gray, no sand, very tight and cohesive, }
$$$$
\text { Sand, gray, coarse, mottled................................................................................. } 12.5-13.0
$$$$
\text { Gravel, blue-gray, clayey ................................................................................................ } 16.0-16.5
$$$$
\text { Clay, gray, unoxidized }
$$

\section{Local number: WC-24-16}

Location: T. 83N., R. 25W., sec. 36 , NE1/4
Date: $5 / 11 / 91$

Aititude of iand surface: 1,0 a feet

\section{Description}

Topsoil, black

Clay, dark-brown, silty

Clay, light-brown, sandy, pebbly, fractures

Clay, light-gray, sandy, silty, abundant fractures, sand lenses, wet, pebbly

Clay, light-brown, sandy, becoming firmer and cohesive with depth

Clay, light-brown, sandy, mottled with light-gray streaks

Clay, blue-green.

Clay, dark-gray, gravelly
Depth intervai (feet)

$$
\begin{array}{r}
0-2.5 \\
2.5-3.0 \\
3.0-6.0 \\
6.0-7.5 \\
7.5-10.0 \\
10.0-12.5 \\
12.5-13.0 \\
13.0-17.5
\end{array}
$$

Local number: WC-25-7

Location: T. 83N., R. 24W., sec. 31, NW1/4

\section{Description}

Topsoil, black

Clay, dark-brown, silty

Clay, light-gray, sandy, pebbly, some fractures

Clay, light-gray, increasing sand content with depth.
Date: 5/11/91

Altitude of iand surface: $1,0^{\prime} ?$ feet

Depth interval (feet) 
Table 2. Descriptive logs of selected boreholes drilled in the Walnut Creek Watershed, Boone and Story Counties, lowa-Continued

Well identification: WC-26-16

Location: T. 83N., R. 24W., sec. 28, SW1/4
Date: 4/4/92

Aititude of land sur'ace: 1,008 feet

Depth Intervai (feet)

\section{Description}

Topsoil, black, organic

Clay, light-brown, rust mottling

Clay, red-brown, sandy, light-gray mottling, very rusty oxidation

Clay, olive-brown, sandy, wet, large rust-red mottles and light-gray streaks

Clay, dark-gray, olive-green mottling

Clay, dark-gray
$0-1.0$

$1.0-2.5$

$2.5-5.0$

$5.0-7.5$

$7.5-9.5$

$9.5-16.5$
Well identification: WC-27-30

Location: T. 82N., R. 24W., sec. 2, NE1/4
Date: 3/26/92

Altitude of land suriace: 969 feet

\section{Description}

\section{Depth interval (feet)}

Topsoil, black, organic

$$
\begin{aligned}
& 0-2.5 \\
& \text { Clay, tan, some sand and gravel ............................................................................... } 2.5-5.0 \\
& \text { Clay, orange-brown, iron stains, disintegrated gravel...................................................... } 7.5-10.0 \\
& 12.5-15.0 \\
& 15.0-20.0 \\
& 20.0-22.5 \\
& 22.5-28.0
\end{aligned}
$$$$
\text { Clay, orange, pebbles, dry ................................................................................ } 5.0-7.5
$$$$
\text { Clay, tan, less orange, iron-stained .................................................................................... } 10.0-12.5
$$$$
\text { Same, less iron }
$$$$
\text { Clay, light-gray, mottled, minor amount of tan clay, pebbles }
$$

Same

Clay, dark-gray, cohesive, firm

Same

Well identification: WC-28-18

Location: T. 82N., R.24W., sec. 2, NE1/4
Date: $3 / 26 / 92$

Altitude of land surface: 980 feet

\section{Description}

Topsoil, black grading to tan, organic

Clay, light-brown, sandy

Clay, tan, very sandy with fine-to-coarse gravel, firmer at 7.5 feet

Clay, tan, sandy, some gravel, oxidized iron stains

Clay, tan, sandy, slightly less sand, dryer, firmer

Clay, tan to brown, sandy, firm.

Clay, dark-gray

No cutting returned

\section{Depth Intervr' (feet)}

$$
\begin{array}{r}
0-2.5 \\
2.5-5.0 \\
5.0-7.5 \\
7.5-10.0 \\
10.0-12.5 \\
12.5-14.0 \\
14.0-15.0 \\
15.0-20.0
\end{array}
$$


Table 2. Descriptive logs of selected boreholes drilled in the Walnut Creek Watershed, Boone and Story Counties, lowa-Continued

Well Identification: WC-29-18

Location: T. 83N., R. 24W., sec. 29, SE1/4

Description

Topsoil, black, organic

Subsoil, brown, clayey, moist.

Clay, tan, sandy, water in hole at 5.0 feet, soft

Same

Same, firmer .

Clay, light-gray, sandy, orange oxidized streaks

Same, tanner, firmer, drier

Clay, dark-gray, sandy, soft

Same
Date: $3 / 27 / 92$

Altitude of land surface: $1,0 \wedge 2$ feet

Depth Interval (feet)
Well Identiflication: WC-30-15

Locatlon: T. 83N., R. 24W., sec. 29, SE1/4
Date: $3 / 27 / 92$

Altitude of land surface: $1,0^{\wedge} 9$ feet

\section{Description}

Depth Interval (feet)

Topsoil, black-brown, organic

$$
\begin{array}{r}
0-2.0 \\
2.0-5.0 \\
5.0-7.5 \\
7.5-10.0 \\
10.0-12.5 \\
13.0-15.0 \\
15.0-20.0
\end{array}
$$$$
\text { Clay, tan, sandy, soft. }
$$$$
\text { Same, mottled with gray, increasingly firm }
$$$$
\text { Same, softer }
$$$$
\text { Same, firmer, iron-mottled }
$$$$
\text { Clay, dark-gray, firm. }
$$

Same

Well Identiflcatlon: WC-31-13

Location: T. 83N., R. 24W., sec. 29, SE1/4
Date: $3 / 27 / 92$

Altitude of land surface: $1,0^{*} 7$ feet

Depth Interval (feet)

\section{Description}
$0-2.0$
$2.0-5.0$
$5.0-7.5$
$7.5-9.0$
$9.0-10.0$
$10.0-15.0$

Topsoil, black, organic

Clay, tan, slightly sandy, some gray mottling

Clay, tan, sandy, soft.

Clay, dark-gray, firm.

Same 
Table 2. Descriptive logs of selected boreholes drilled in the Walnut Creek Watershed, Boone and Story Counties, lowa-Continued

Well Identification: WC-32-16

Location: T. 83N., R. 24W., sec. 29, SE1/4
Date: $4 / 2 / 92$

Alttude of land surf me: 1,007 feet

Depth Interve" (feet)

Description

$0-2.0$

Topsoil, black, organic $2.0-5.0$

Same

$5.0-6.0$

Clay, dark gray-black, sandy

$6.0-7.0$

Clay, tan, sandy, mottled black.

Clay, tan, sandy, mottled gray

Clay, dark-gray, sandy

Same.

$7.0-10.0$

$10.0-11.5$

$11.5-16.5$
Well identification: WC-33-16

Location: T. 83N., R. 24W., sec. 29, SE1/4

Description
Date: 4/3/92

Altitude of land surf $;=0$ 1,008 feet

Depth Interva' (feet)

Topsoil, black, organic $0-1.0$

Clay, brown, sandy, pebbles

$1.0-3.0$

Clay, as above, with rust-red and light-gray mottling

Same, deeper red mottling.

$3.0-6.0$

$6.0-7.5$

$7.5-9.5$

Clay, dark-gray, rust mottling

Clay, dark-gray
$9.5-16.5$
Well identification: WC-34-16

Location: T. 83N., R. 24W., sec. 29, SE1/4
Date: 4/2/92

Altitude of land surfire: 1,004 feet

Depth Interva' (feet)

\section{Description}

Topsoil, black, organic

$0-3.0$

Clay, olive-gray, mottled with iron stains

$3.0-5.0$

Clay, olive-gray

$5.0-6.0$

Clay, olive-gray, sandy, mottled with reddish-brown and gray clay

$6.0-9.0$

Clay, dark-gray, very firm, pebbly. 
Table 2. Descriptive logs of selected boreholes drilled in the Walnut Creek Watershed, Boone and Story Counties, lowa-Continued

Weii Identification: WC-35-17

Location: T. 83N., R. 24W., sec. 29, SE1/4
Date: $4 / 3 / 92$

Altitude of iand surface: 1,074 feet
Description

Topsoil, black, organic

Clay, brown-gray, sandy, pebbles

Same

Clay, brown, rust-red and gray mottles

Clay, olive-gray, sandy, pebbly, rust-red and light-gray mottling

Same, some dark rust-brown mottling, wet.....

Clay, dark-gray, some rust-dark green mottles.

Clay, dark-gray, dense
Depth Intervai (feet)

$$
\begin{array}{r}
0-1.0 \\
1.0-3.0 \\
3.0-4.0 \\
4.0-5.0 \\
5.0-7.5 \\
7.5-8.5 \\
8.5-10.5 \\
10.5-18.0
\end{array}
$$

Date: $4 / 4 / 92$

Weil identiflcation: WC-36-24

Locatlon: T. 83N., R. 25W., sec. 24, SE1/4

Aitlude of iand surface: 1,014 feet

\section{Description}

\section{Depth Intervai (feet)}

Topsoil, black, organic

$$
\begin{array}{r}
0-1.5 \\
1.5-4.0 \\
4.0-5.0 \\
5.0-8.0 \\
8.0-11.0 \\
11.0-14.0 \\
14.0-16.0 \\
17.0-18.0 \\
18.0-20.0 \\
20.0-26.0
\end{array}
$$

Date: $4 / 3 / 92$

Weil Identification: WC-37-17

Locatlon: T. 83N., R. 25W., sec. 24, NE1/4

Aititude of land surface: $1,0 \times 1$ feet

\section{Description}

Depth intervai (feet)

Topsoil, black, organic

$$
\begin{array}{r}
0-1.0 \\
1.0-3.0 \\
3.0-4.0 \\
4.0-6.0 \\
6.0-7.5 \\
7.5-10.0 \\
10.0-17.5
\end{array}
$$$$
\text { Clay, gray, sandy }
$$ 
Table 2. Descriptive logs of selected boreholes drilled in the Walnut Creek Watershed, Boone and Story Counties, lowa-Continued

Well Identffication: WC-38-17

Location: T. 83N., R. 25W., sec. 24, NE1/4

Date: $4 / 3 / 92$

Aftitude of land surfire: 1,029 feet

Description

Depth interva' (feet)

Topsoil, black, organic

$0-1.0$
$1.0-2.5$
$2.5-6.0$
$6.0-7.5$
$7.5-9.5$
$9.5-17.0$

Clay, brown-black

Clay, brown, sandy, mottled rust and light-gray, pebbles

Same, more gray mottling, firmer.

Clay, dark-gray, olive-green mottling

Clay, dark-gray.

$9.5-17.0$ 
Table 3. Local numbers and construction data for selected wells drilled in the Walnut Creek Watershed, Bnone and Story Counties, lowa

\begin{tabular}{|c|c|c|c|c|c|}
\hline $\begin{array}{l}\text { Local } \\
\text { number }\end{array}$ & $\begin{array}{c}\text { SIte Identlficatlon } \\
\text { (iatltude, iongitude, and } \\
\text { 2-digit sequential number) }\end{array}$ & $\begin{array}{l}\text { Land-surface aititude } \\
\text { (feet above sea level) }\end{array}$ & $\begin{array}{l}\text { Helght of measuring } \\
\text { polnt above } \\
\text { land surface } \\
\text { (feet) }\end{array}$ & $\begin{array}{l}\text { Depth o } \\
\text { Inter } \\
\text { land }\end{array}$ & $\begin{array}{l}\text { of screened } \\
\text { val belc'w } \\
\text { d surfac? } \\
\text { (feet) }\end{array}$ \\
\hline WC-1-6 & 415754093385301 & $1,007.70$ & 3.10 & 5.0 & -7.5 \\
\hline WC-1-9. & 415754093385302 & $1,007.87$ & 2.60 & 7.5 & -10.0 \\
\hline WC-1-14 & 415754093385303 & $1,007.84$ & 2.90 & 12.5 & -15.0 \\
\hline$W C-2-4$ & 415756093391001 & 999.28 & 2.00 & 2.5 & -5.0 \\
\hline WC-2-6 & 415756093391002 & 999.35 & 1.80 & 5.0 & -7.5 \\
\hline WC-2-9 & 415756093391003 & 999.29 & 1.90 & 7.5 & -10.0 \\
\hline WC-2-14 & 415756093391004 & 999.00 & 1.80 & 12.5 & -15.0 \\
\hline WC-2-21 & 415756093391005 & 998.33 & 2.70 & 20.0 & -22.5 \\
\hline WC $-3-4$ & 415754093390701 & $1,001.44$ & 1.65 & 2.5 & -5.0 \\
\hline$W C-3-6$ & 415754093390702 & $1,000.45$ & 3.10 & 4.5 & -7.0 \\
\hline WC-3-11 & 415754093390703 & $1,000.32$ & 2.60 & 10.0 & -12.5 \\
\hline WC-4-9 & 415752093413101 & $1,037.19$ & 2.75 & 8.0 & -10.5 \\
\hline WC-4-16 & 415752093413102 & $1,037.34$ & 2.65 & 15.0 & -17.5 \\
\hline WC-5-6 & 415755093420702 & $1,037.54$ & 2.65 & 5.0 & -7.5 \\
\hline WC-5-14 & 415755093420701 & $1,037.46$ & 2.55 & 12.5 & -15.0 \\
\hline WC-6-9 & 415748093405601 & $1,026.92$ & 2.70 & 8.0 & -10.5 \\
\hline WC-6-19 & 415748093405602 & $1,027.09$ & 2.70 & 18.0 & -20.5 \\
\hline WC-7-6 & 415801093415401 & $1,036.46$ & 2.25 & 5.0 & -7.5 \\
\hline WC-7-9 & 415801093415402 & $1,036.61$ & 2.15 & 8.0 & -10.5 \\
\hline WC-7-14 & 415801093415403 & $1,036.55$ & 2.25 & 13.0 & -15.5 \\
\hline WC-7-21 & 415801093415404 & $1,036.67$ & 2.35 & 20.0 & -22.5 \\
\hline WC-8-14 & 415730093415501 & $1,041.51$ & 2.30 & 13.0 & -15.5 \\
\hline WC-8-19 & 415730093415502 & $1,041.52$ & 2.30 & 18.0 & -20.5 \\
\hline WC-9-4 & 415809093415501 & $1,034.72$ & 2.25 & 3.0 & -5.5 \\
\hline WC-9-7 & 415809093415502 & $1,035.11$ & 2.25 & 6.0 & -8.5 \\
\hline WC-9-13 & 415809093415503 & $1,034.98$ & 3.50 & 12.0 & -14.5 \\
\hline WC-10-5 & 415814093421001 & $1,036.17$ & 2.10 & 3.5 & -6.0 \\
\hline WC-10-10 & 415814093421002 & $1,036.11$ & 1.95 & 8.5 & -11.0 \\
\hline WC-10-17 & 415814093421003 & $1,036.17$ & 2.25 & 16.0 & -18.5 \\
\hline WC-11-6 & 415804093421001 & $1,038.86$ & 2.90 & 5.0 & -7.5 \\
\hline WC-11-10 & 415804093421002 & $1,038.84$ & 1.40 & 9.0 & -11.5 \\
\hline WC-11-15 & 415804093421003 & $1,038.87$ & 1.60 & 14.0 & -16.5 \\
\hline
\end{tabular}


Table 3. Local numbers and construction data for selected wells drilled in the Walnut Creek Watershed, Boone and Story Counties, lowa-Continued

\begin{tabular}{|c|c|c|c|c|c|}
\hline $\begin{array}{l}\text { Local } \\
\text { number }\end{array}$ & $\begin{array}{l}\text { Site identification } \\
\text { (latitude, longltude, and } \\
\text { 2-digit sequential number) }\end{array}$ & $\begin{array}{l}\text { Land-surface altitude } \\
\text { (feet above sea level) }\end{array}$ & $\begin{array}{l}\text { Helght of measuring } \\
\text { polnt above } \\
\text { land surface } \\
\text { (feet) }\end{array}$ & $\begin{array}{r}\text { Depth } \\
\text { Inter } \\
\text { lan }\end{array}$ & $\begin{array}{l}\text { of screened } \\
\text { val below } \\
\text { t surface } \\
\text { (feet) }\end{array}$ \\
\hline WC-12-10 & 415742093415601 & $1,034.69$ & 1.65 & 9.0 & -11.5 \\
\hline WC-12-16 & 415742093415602 & $1,034.58$ & 3.00 & 15.0 & -17.5 \\
\hline WC-13-6 & 415726093404403 & $1,034.18$ & 2.70 & 5.0 & -7.5 \\
\hline WC-13-18 & 415726093404401 & $1,033.87$ & 3.30 & 17.0 & -19.5 \\
\hline WC-13-24 & 415726093404402 & $1,033.99$ & 2.25 & 23.0 & -25.5 \\
\hline WC-14-6 & 415726093410703 & $1,034.13$ & 2.60 & 5.0 & -7.5 \\
\hline WC-14-11 & 415726093410701 & $1,034.00$ & 2.90 & 10.0 & -12.5 \\
\hline WC-14-16 & 415726093410702 & $1,034.23$ & 2.70 & 15.0 & -17.5 \\
\hline WC-15-5 & 415758093393301 & $1,002.81$ & 4.15 & 4.0 & -6.5 \\
\hline WC-15-9 & 415758093393302 & $1,002.60$ & 2.45 & 8.0 & -10.5 \\
\hline WC-15-16 & 415758093393303 & $1,002.89$ & 3.50 & 14.5 & -17.0 \\
\hline WC-16-6 & 415747093430101 & $1,053.96$ & 3.10 & 5.0 & -7.5 \\
\hline WC-16-16 & 415747093430102 & $1,053.70$ & 2.95 & 15.0 & -17.5 \\
\hline WC-17-4 & 415806093400001 & $1,006.72$ & 3.00 & 3.0 & -5.5 \\
\hline WC-17-6 & 415806093400002 & $1,006.54$ & 3.00 & 5.0 & -7.5 \\
\hline WC-17-9 & 415806093400003 & $1,006.58$ & 3.20 & 7.5 & -10.0 \\
\hline WC-17-14 & 415806093400004 & $1,006.45$ & 3.10 & 12.5 & -15.0 \\
\hline WC-18-9 & 415729093413101 & $1,033.97$ & 2.93 & 7.5 & -10.0 \\
\hline WC-19-4 & 415759093394501 & $1,003.99$ & 2.85 & 2.5 & -5.0 \\
\hline WC-19-6 & 415759093394502 & $1,003.85$ & 3.10 & 5.0 & -7.5 \\
\hline WC-19-9 & 415759093394503 & $1,003.96$ & 2.90 & 7.5 & -10.0 \\
\hline WC-19-14 & 415759093394504 & $1,003.92$ & 3.33 & 10.0 & -12.5 \\
\hline WC-20-9 & 415728093424401 & $1,052.30$ & 2.90 & 7.5 & -10.0 \\
\hline WC-20-16 & 415728093424402 & $1,052.20$ & 3.15 & 14.5 & -17.0 \\
\hline WC-21-6 & 415729093425401 & $1,046.27$ & 3.24 & 5.0 & -7.5 \\
\hline WC-21-14 & 415729093425402 & $1,046.30$ & 2.90 & 13.0 & -15.5 \\
\hline WC-22-6 & 415747093424601 & $1,043.14$ & 2.91 & 5.0 & -7.5 \\
\hline WC-22-14 & 415747093424602 & $1,043.23$ & 2.72 & 12.5 & -15.0 \\
\hline WC-23-9 & 415728093422701 & $1,044.61$ & 2.68 & 7.5 & -10.0 \\
\hline WC-23-16 & 415728093422702 & $1,044.70$ & 2.90 & $15 . C$ & -17.5 \\
\hline
\end{tabular}


Table 3. Local numbers and construction data for selected wells drilled in the Walnut Creek Watershed, Boone and Story Counties, lowa-Continued

\begin{tabular}{|c|c|c|c|c|}
\hline $\begin{array}{l}\text { Locai } \\
\text { number }\end{array}$ & $\begin{array}{c}\text { Site Identiflcation } \\
\text { (latitude, longitude, and } \\
\text { 2-dlgit sequential number) }\end{array}$ & $\begin{array}{l}\text { Land-surface altitude } \\
\text { (feet above sea level) }\end{array}$ & $\begin{array}{l}\text { Helght of measuring } \\
\text { point above } \\
\text { land surface } \\
\text { (feet) }\end{array}$ & $\begin{array}{l}\text { Depth of scrmaned } \\
\text { Interval be'ow } \\
\text { iand surfare } \\
\text { (feet) }\end{array}$ \\
\hline WC-24-9 & 415740093422601 & $1,045.73$ & 2.57 & $8.0-10.5$ \\
\hline WC-24-16 & 415740093422602 & $1,046.27$ & 3.60 & $15.0-17.5$ \\
\hline WC-25-7 & 415739093413101 & $1,031.68$ & 3.11 & $5.5-8.0$ \\
\hline WC-26-3 & 415759093384601 & $1,008.36$ & 1.40 & $1.0-3.5$ \\
\hline WC-26-6 & 415759093384602 & $1,008.40$ & 1.31 & $4.0-6.5$ \\
\hline WC-26-16 & 415759093384603 & $1,008.39$ & 1.17 & $14.0-16.5$ \\
\hline WC-27-15 & 415646093362201 & 969.58 & 3.38 & $14.0-16.5$ \\
\hline WC-27-20 & 415646093362202 & 969.01 & 3.27 & $18.0-20.5$ \\
\hline WC-27-30 & 415646093362203 & 969.38 & 3.40 & $29.0-31.5$ \\
\hline WC-28-7 & 415642093362801 & 980.03 & 1.71 & $6.0-8.5$ \\
\hline WC-28-11 & 415642093362802 & 980.02 & 2.96 & $10.0-12.5$ \\
\hline WC-28-18 & 415642093362803 & 980.02 & 1.02 & $16.5-19.0$ \\
\hline WC-29-3 & 415807093395401 & $1,012.72$ & 1.10 & $2.0-4.5$ \\
\hline WC-29-9 & 415807093395402 & $1,012.65$ & 0.75 & $8.0-10.5$ \\
\hline WC-29-18 & 415807093395403 & $1,012.36$ & 0.89 & $16.5-19.0$ \\
\hline$W C-30-4$ & 415808093394701 & $1,018.29$ & 0.94 & $2.0-4.5$ \\
\hline WC-30-8 & 415808093394702 & $1,018.60$ & 0.63 & $6.5-9.0$ \\
\hline WC-30-15 & 415808093394703 & $1,018.58$ & 0.96 & $14.0-16.5$ \\
\hline WC-31-6 & 415808093393301 & $1,017.22$ & 0.70 & $4.0-6.5$ \\
\hline WC-31-13 & 415808093393302 & $1,017.22$ & 0.50 & $11.5-14.0$ \\
\hline WC $-32-4$ & 415801093395501 & $1,007.11$ & 2.85 & $3.0-5.5$ \\
\hline WC-32-10 & 415801093395502 & $1,007.11$ & 2.60 & $8.0-10.5$ \\
\hline WC-32-16 & 415801093395503 & $1,007.10$ & 1.56 & $14.0-16.5$ \\
\hline WC-33-6 & 415755093400101 & $1,007.73$ & 1.19 & $4.0-6.5$ \\
\hline WC-33-16 & 415755093400102 & $1,007.54$ & 1.63 & $14.0-16.5$ \\
\hline WC-34-5 & 415756093393901 & $1,004.21$ & 2.29 & $3.0-5.5$ \\
\hline WC-34-16 & 415756093393902 & $1,004.15$ & 2.84 & $14.0-16.5$ \\
\hline WC-34-30 & 415756093393903 & $1,004.18$ & 3.29 & $28.0-30.5$ \\
\hline
\end{tabular}


Table 3. Local numbers and construction data for selected wells drilled in the Walnut Creek Water:hed, Boone and Story Counties, lowa-Continued

\begin{tabular}{|c|c|c|c|c|}
\hline $\begin{array}{l}\text { Local } \\
\text { number }\end{array}$ & $\begin{array}{c}\text { Site identification } \\
\text { (latitude, longitude, and } \\
\text { 2-digit sequentlal number) }\end{array}$ & $\begin{array}{l}\text { Land-surface altitude } \\
\text { (feet above sea level) }\end{array}$ & $\begin{array}{l}\text { Height of measuring } \\
\text { point above } \\
\text { land surface } \\
\text { (feet) }\end{array}$ & $\begin{array}{l}\text { Depth of screened } \\
\text { Inter'al below } \\
\text { land surface } \\
\text { (feet) }\end{array}$ \\
\hline WC-35-3 & 415754093393901 & $1,004.02$ & 1.71 & $1.0-3.5$ \\
\hline WC-35-6 & 415754093393902 & $1,004.01$ & 1.83 & $3.5-6.0$ \\
\hline WC-35-17 & 415754093393903 & $1,003.84$ & 1.44 & $15.0-17.5$ \\
\hline WC-36-8 & 415847093421601 & $1,043.82$ & 2.13 & $6.0-8.5$ \\
\hline WC-36-13 & 415847093421602 & $1,043.58$ & 2.19 & $11.0-13.5$ \\
\hline WC-36-24 & 415847093421603 & $1,043.78$ & 2.45 & $22.0-24.5$ \\
\hline WC-37-3 & 415913093421001 & $1,030.61$ & 2.00 & $1.0-3.5$ \\
\hline WC-37-6 & 415913093421002 & $1,030.45$ & 1.00 & $4.0-6.5$ \\
\hline WC-37-17 & 415913093421003 & $1,030.50$ & 3.10 & $15.0-17.5$ \\
\hline WC-38-3 & 415933093421001 & $1,028.11$ & 2.00 & $1.0-3.5$ \\
\hline WC-38-6 & 415933093421002 & $1,028.52$ & 1.04 & $4.0-6.5$ \\
\hline WC-38-17 & 415933093421003 & $1,029.28$ & 2.01 & $15.0-17.5$ \\
\hline
\end{tabular}




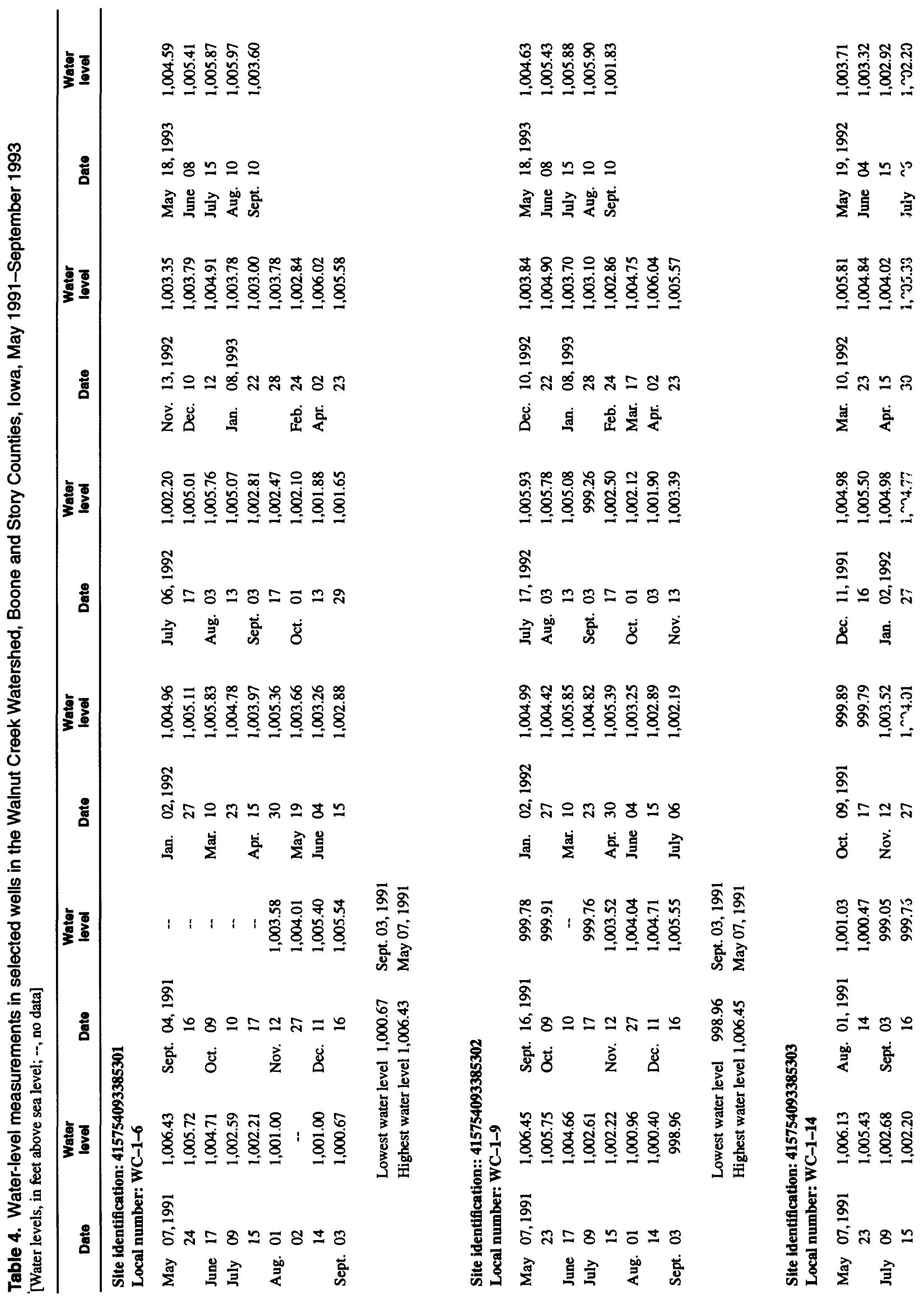




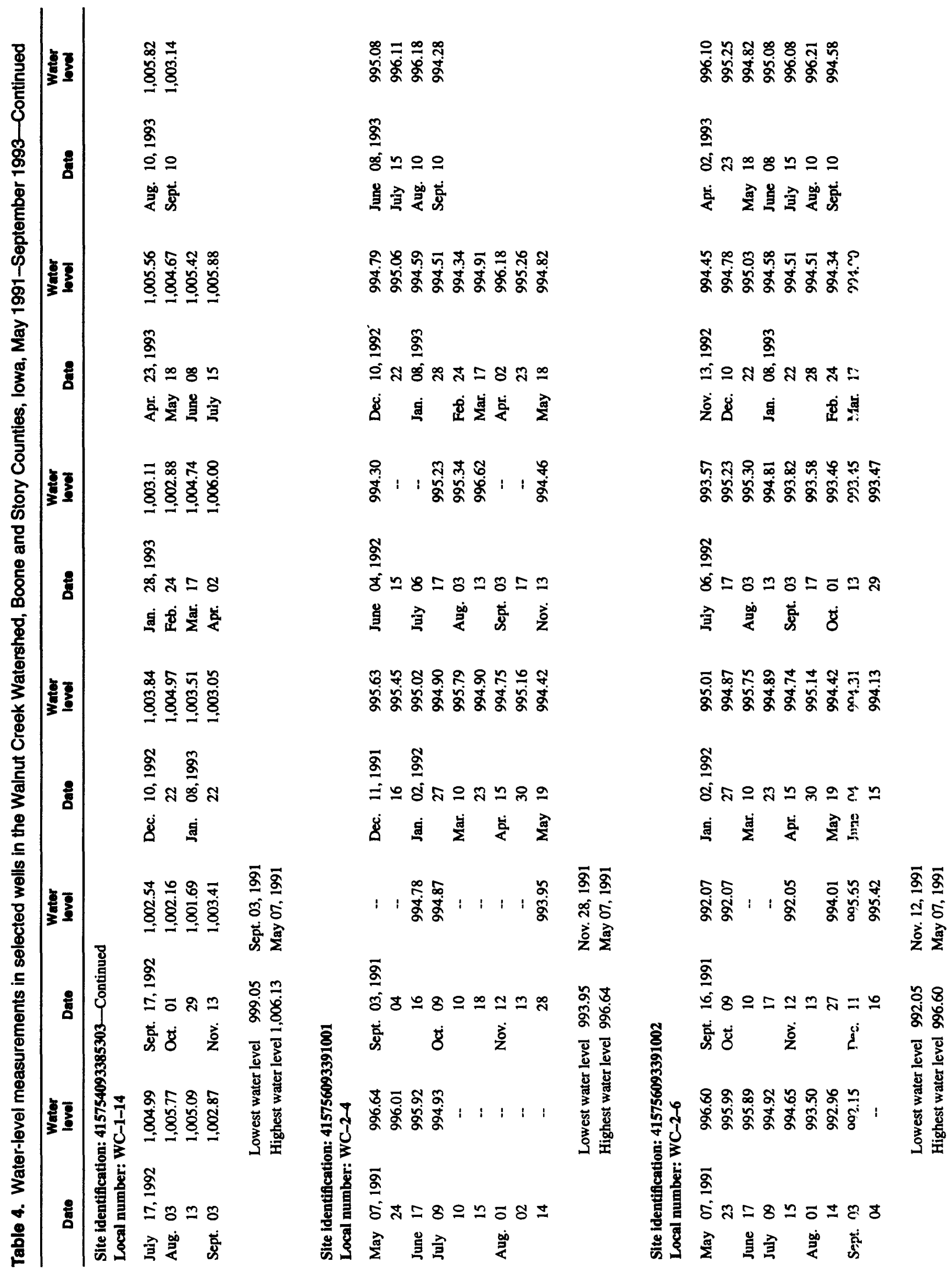




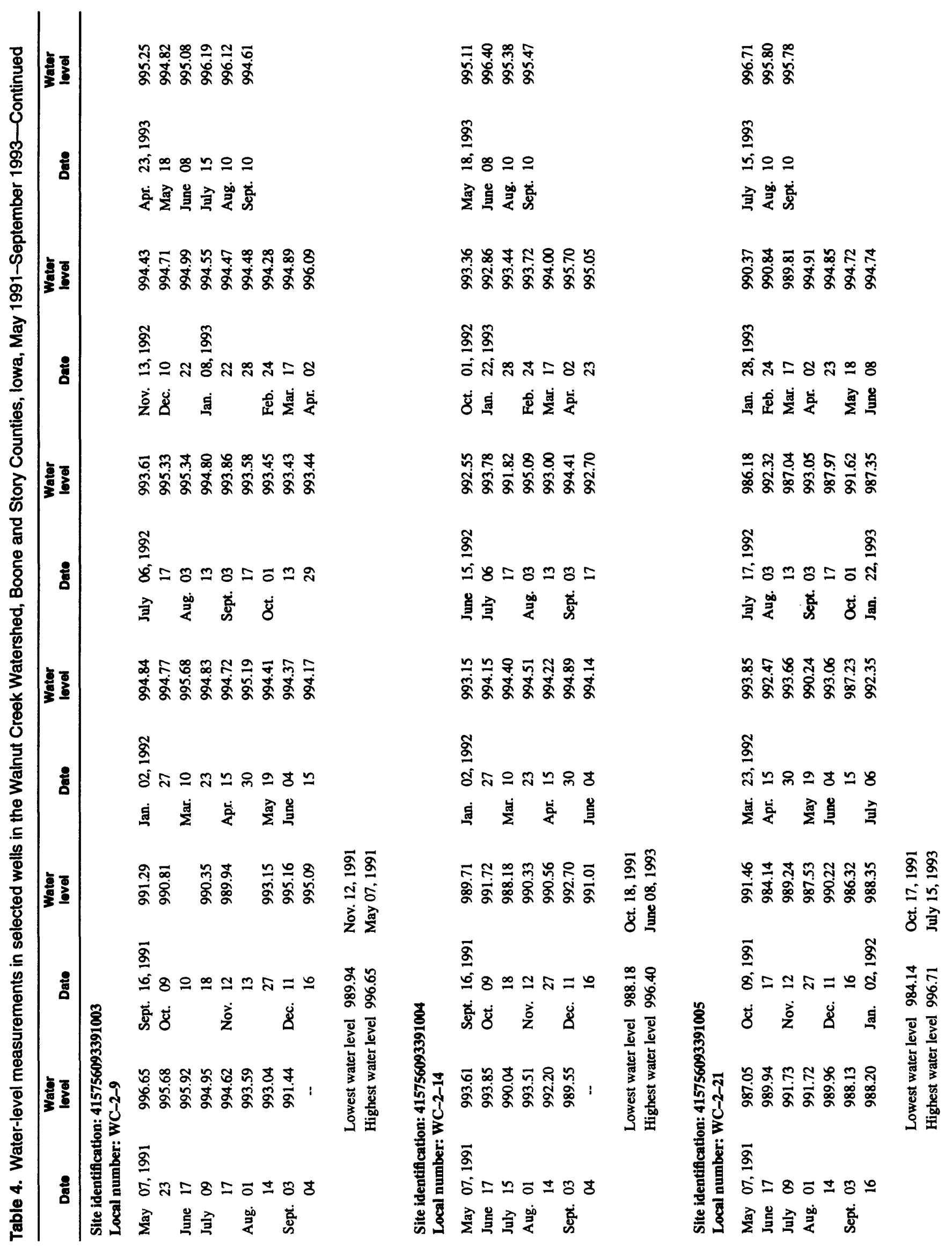




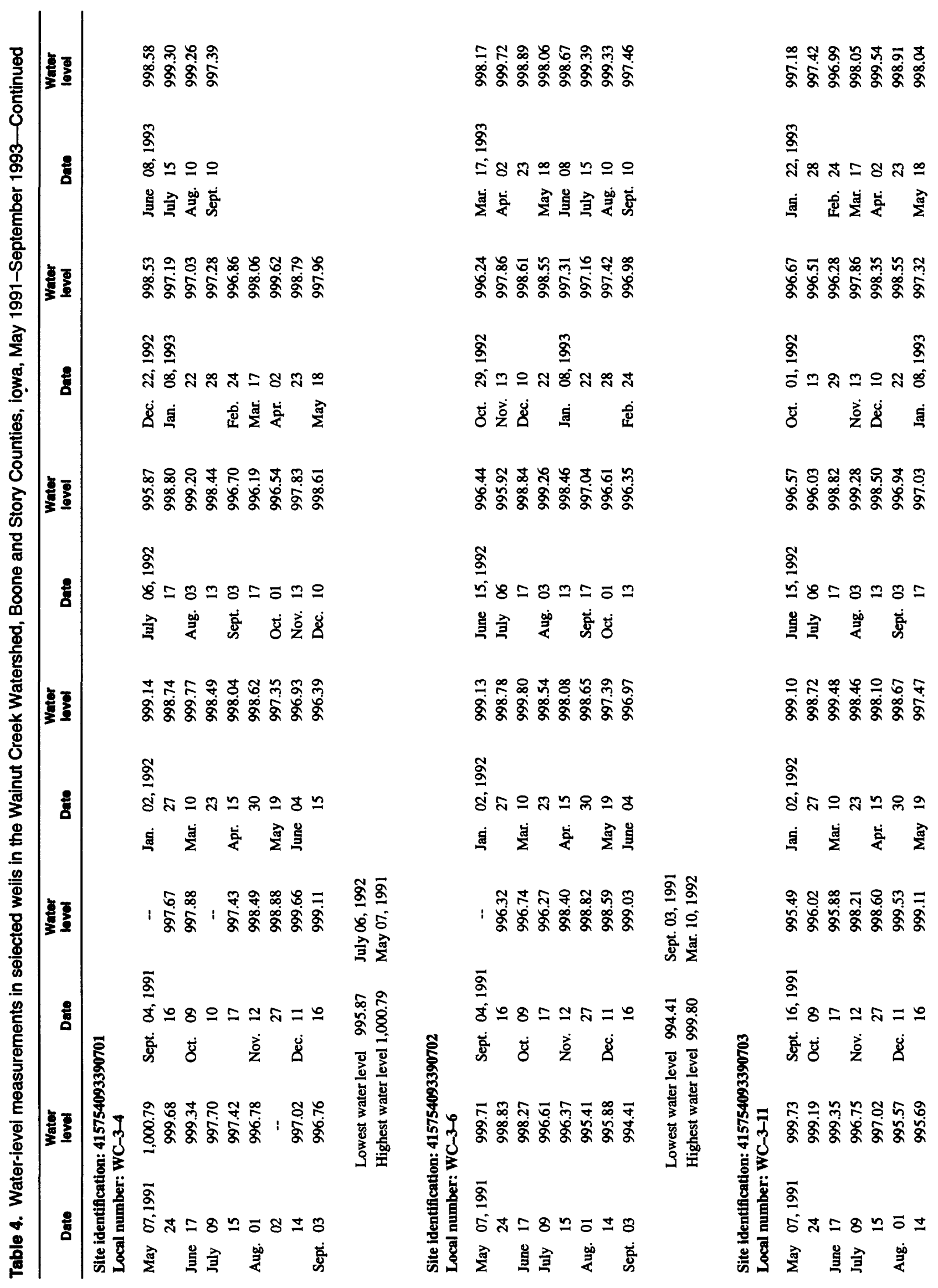




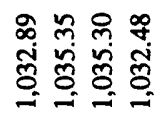

gั

$\stackrel{\infty}{\sim} \div$

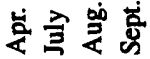

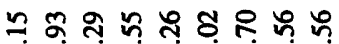

웅

รั

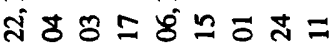

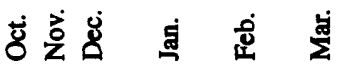

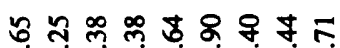

क्ष

รั

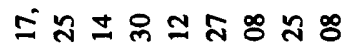

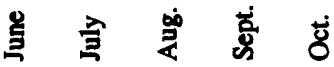

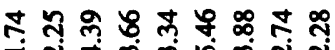

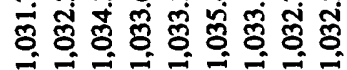

รั

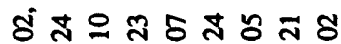

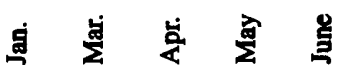

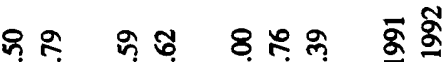

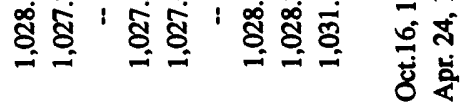

s $\overline{8}$

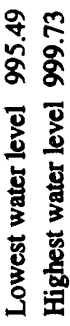

$\bar{\alpha} \bar{g}$

$\div 5$

总要

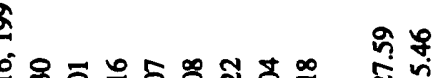

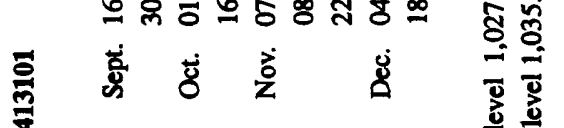

客

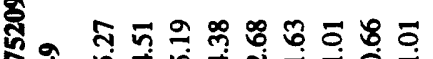

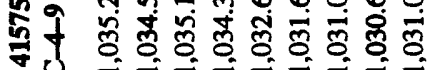

$\ddot{3}$

हुํำ

ปั่สล

焉

要总咅最
पా

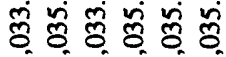

\%

ำระิ

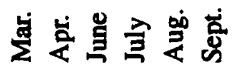

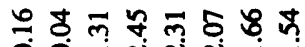

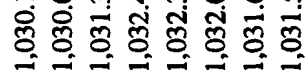

๙

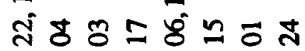

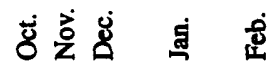

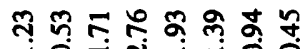

突

๙

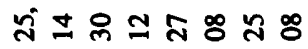

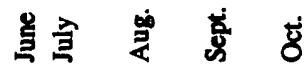

สิ ดิ สิ

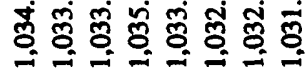

ริ

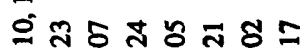

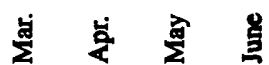

๑

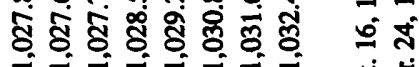
这家 बี कू

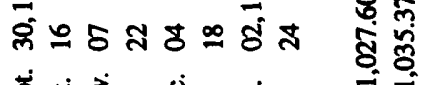

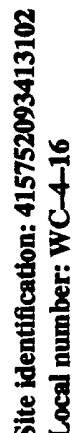

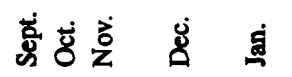
$\overline{8}$ 政

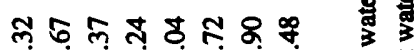

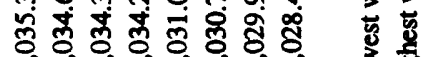
高整

s

รี่ ส

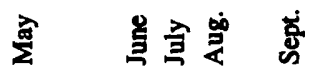




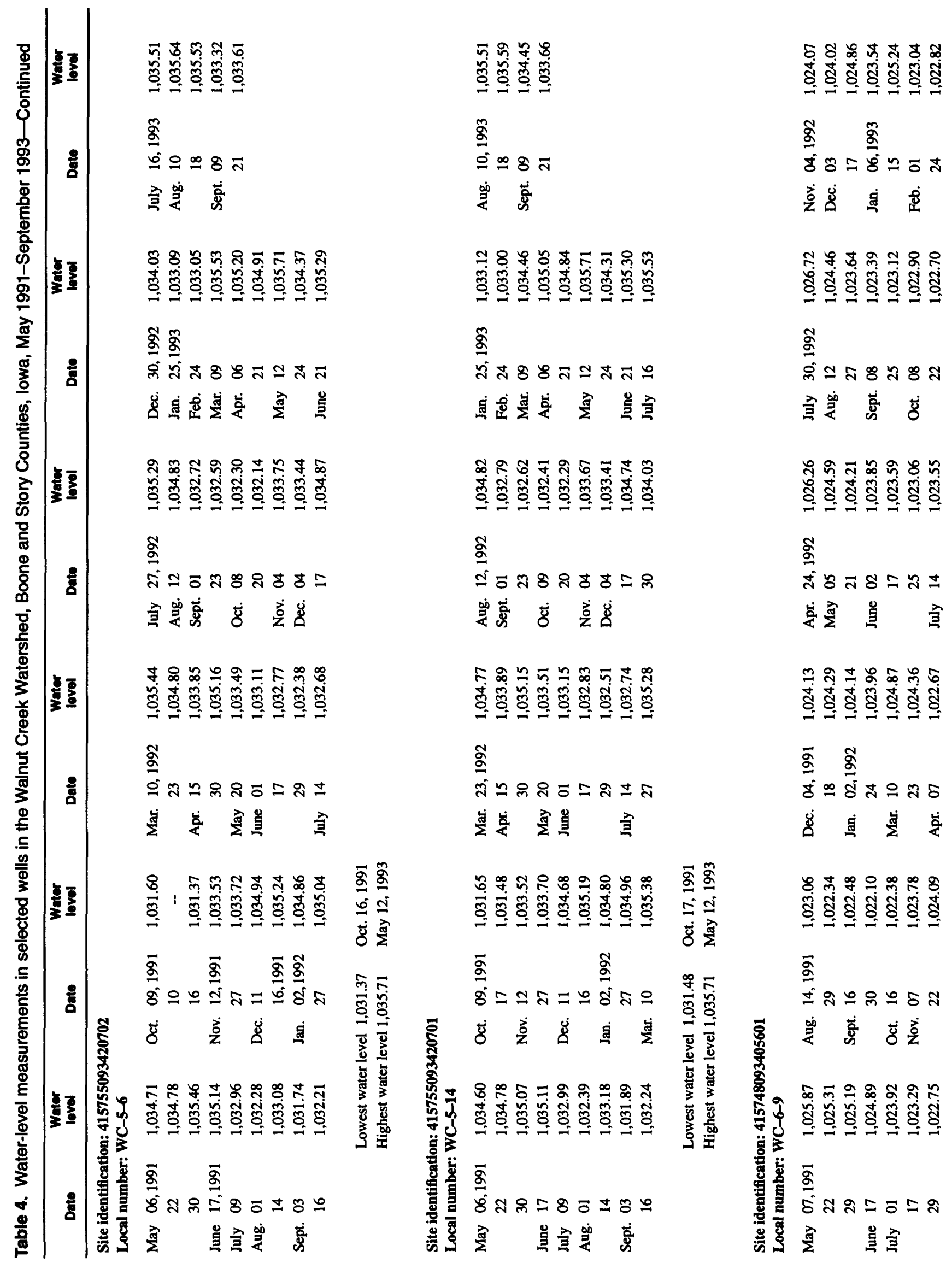


๙

杖

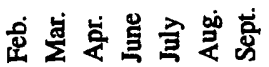

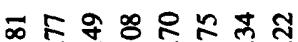

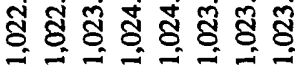

๙

ถึ สษ

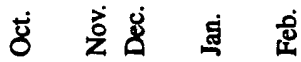

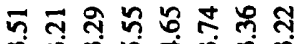

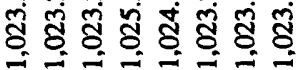

รั

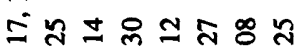

点至安范

ㄲำ

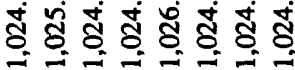

ริ

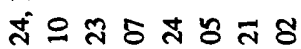

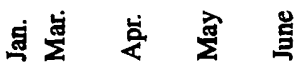

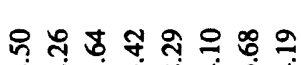

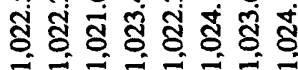

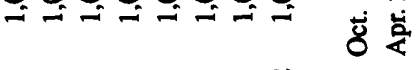

ळ

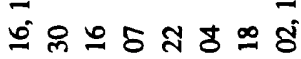

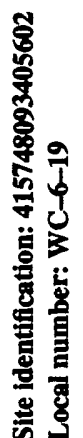

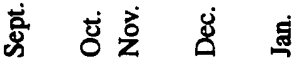

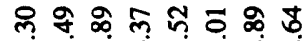

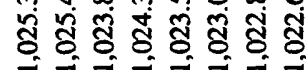

$\overline{5}$

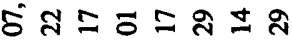

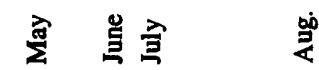

รี ฐี

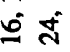

范 g

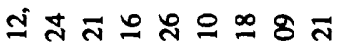

要总沓离

กิ

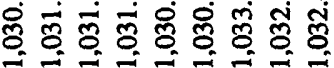

สิ

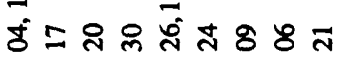

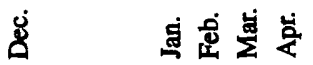

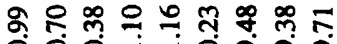

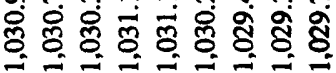

๙ั

ปั่

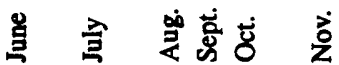

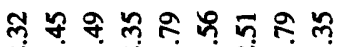

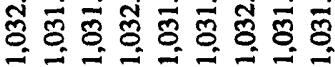

รั ฐ

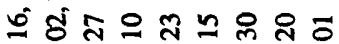

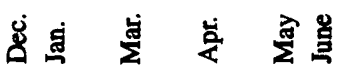

零

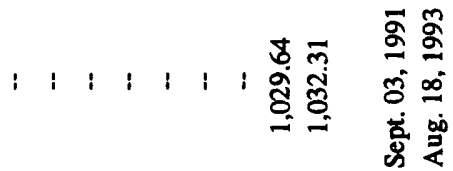

హ.

สำㄴำ

ชำㅇำ

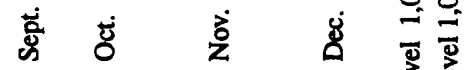

产

莺

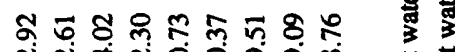

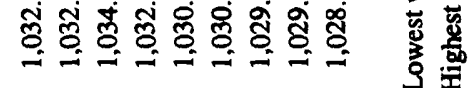

恶

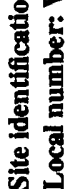

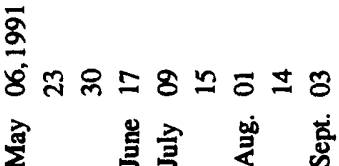




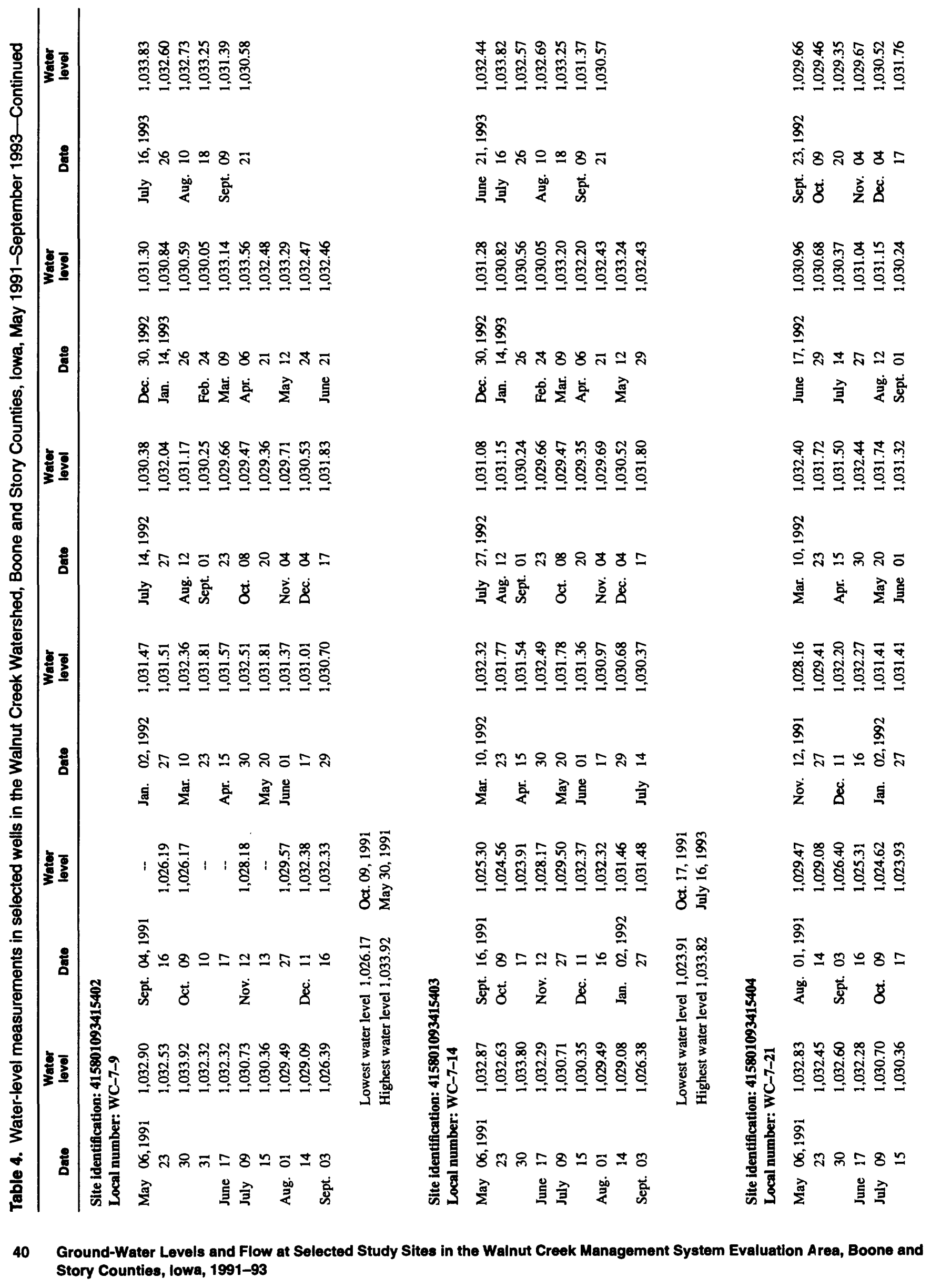




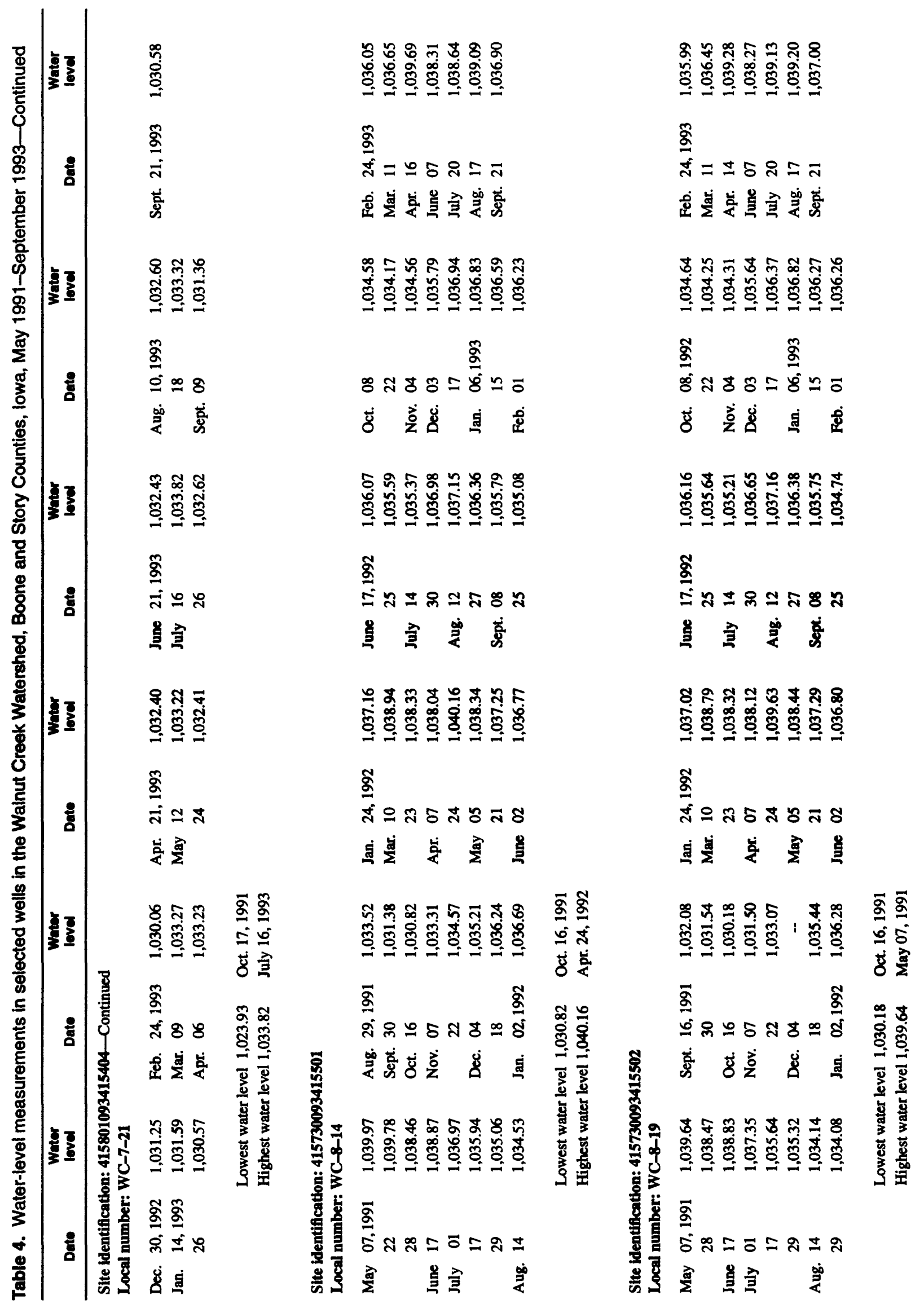




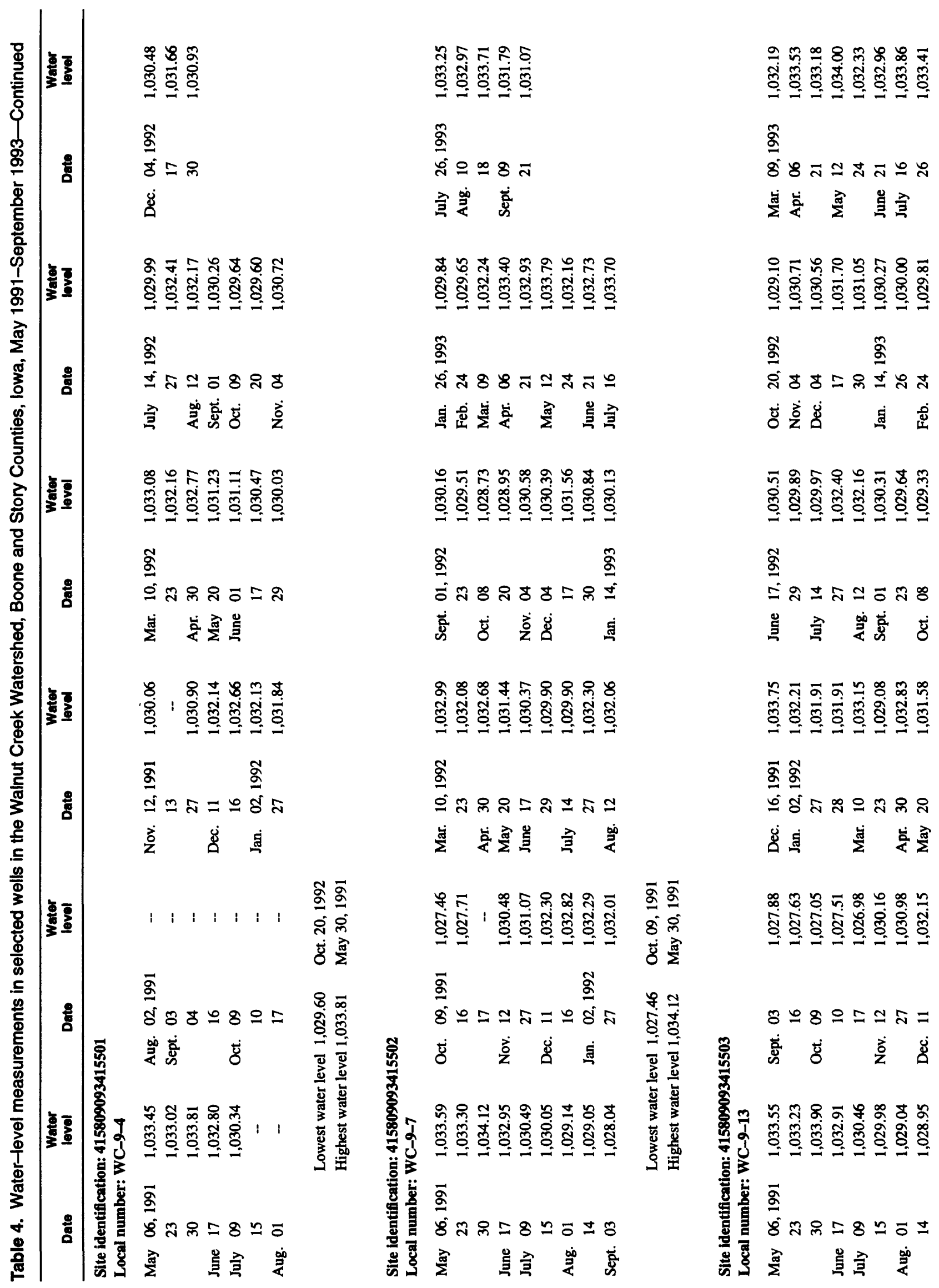




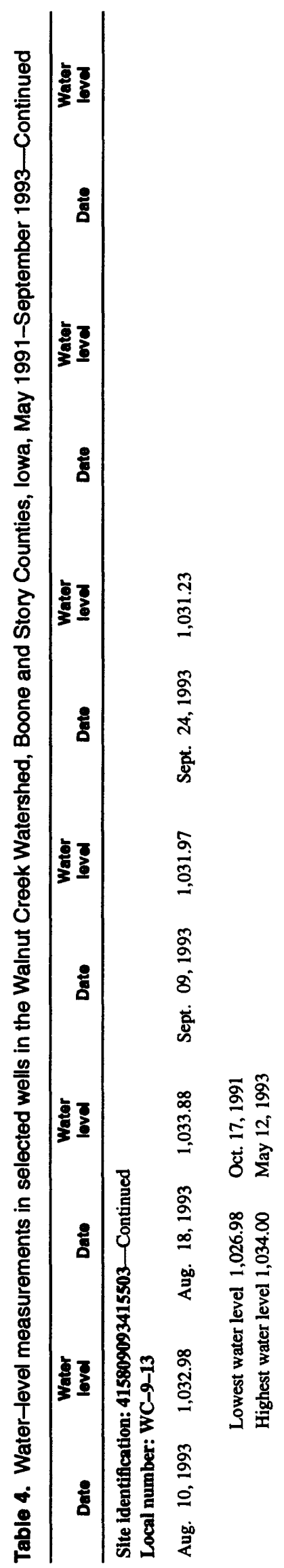

돌.

$8 \div 78$ 웅

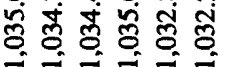

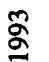

สㄴํำ요요

ळ

意空恶

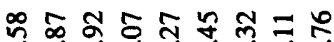

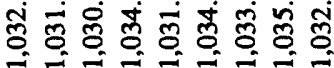

๙

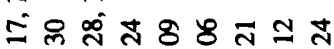

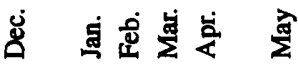

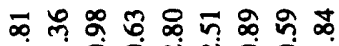

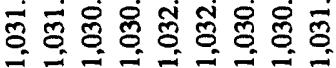

๙

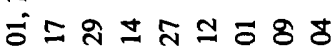

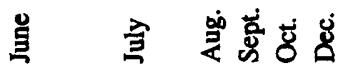

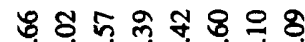

1

Бั

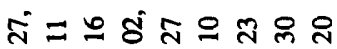

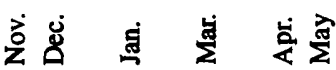

รู

: : : : : 1 1: $1:$ : 8

ठํ.

$\bar{g}$

兽

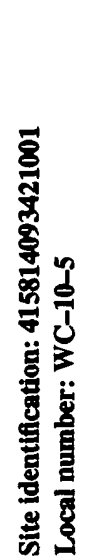

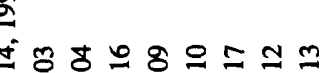

ถิ글

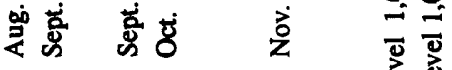

象

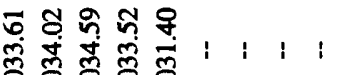

氨

要

荡落

\section{$\overline{\mathrm{g}}$}

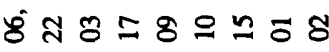

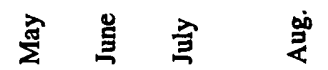




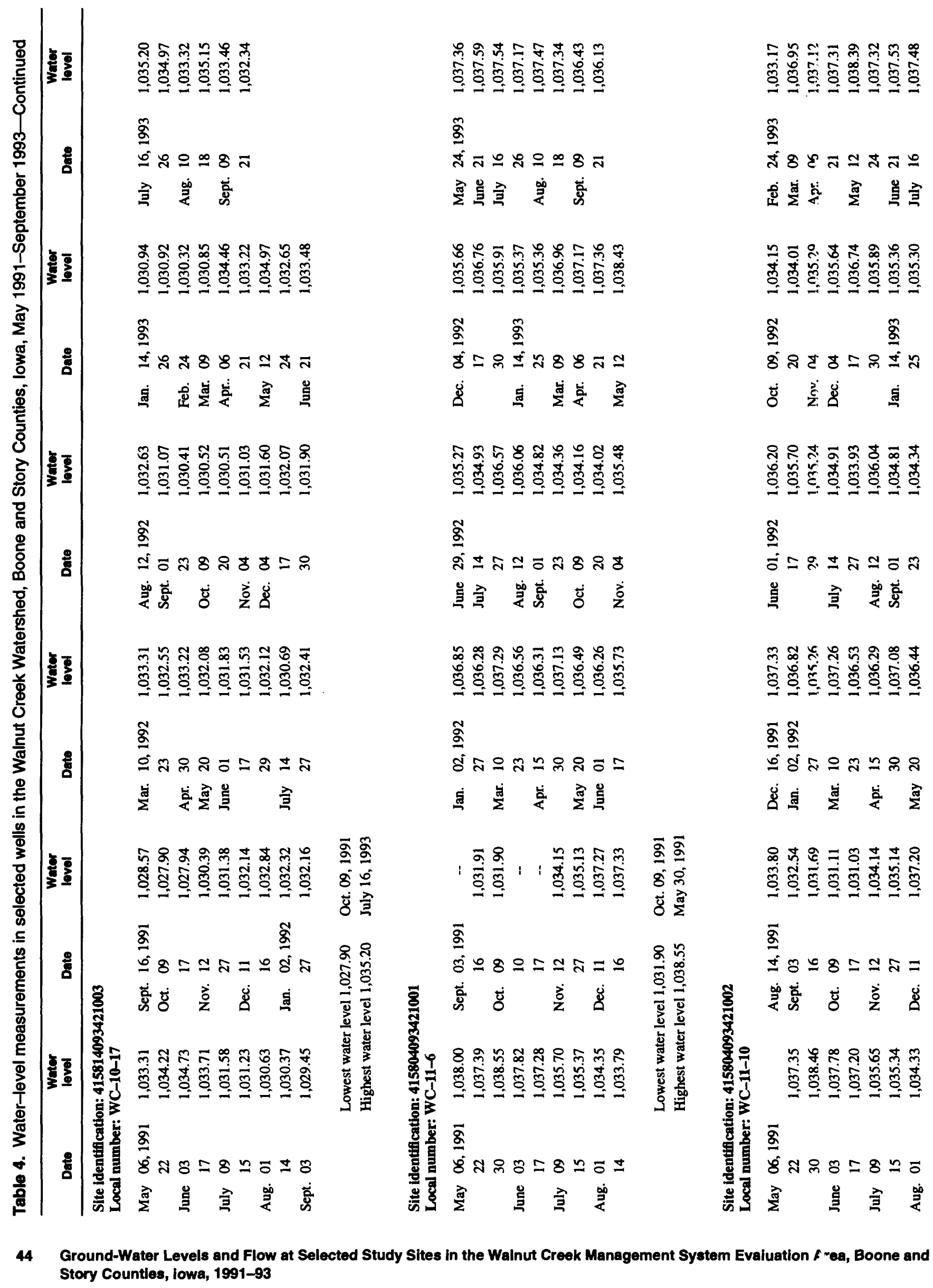




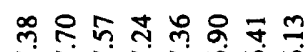

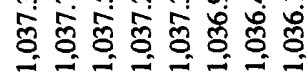

\%

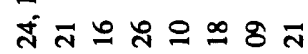

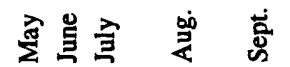

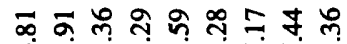

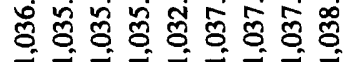

๙

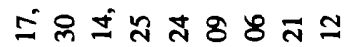

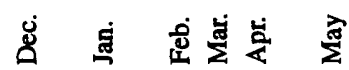

ㅇำ

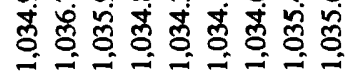

รั

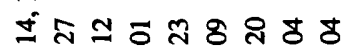

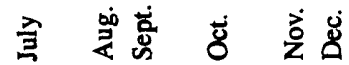

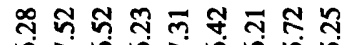

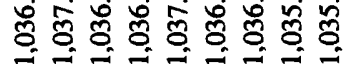

๙ั

ํํㅇำำㅇำ

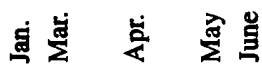

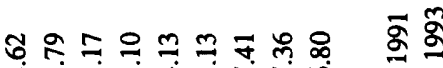

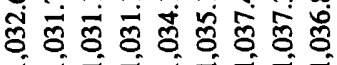

远

ลे

รำำง

危 离

ริำ

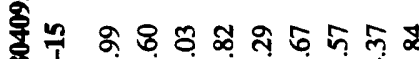

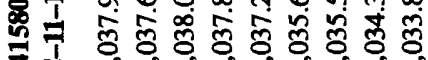

范

䓃

$\frac{5}{8}$

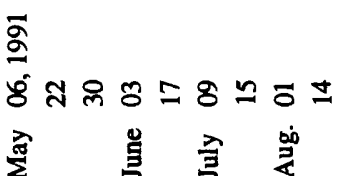

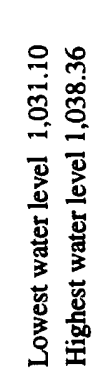

도ำ 


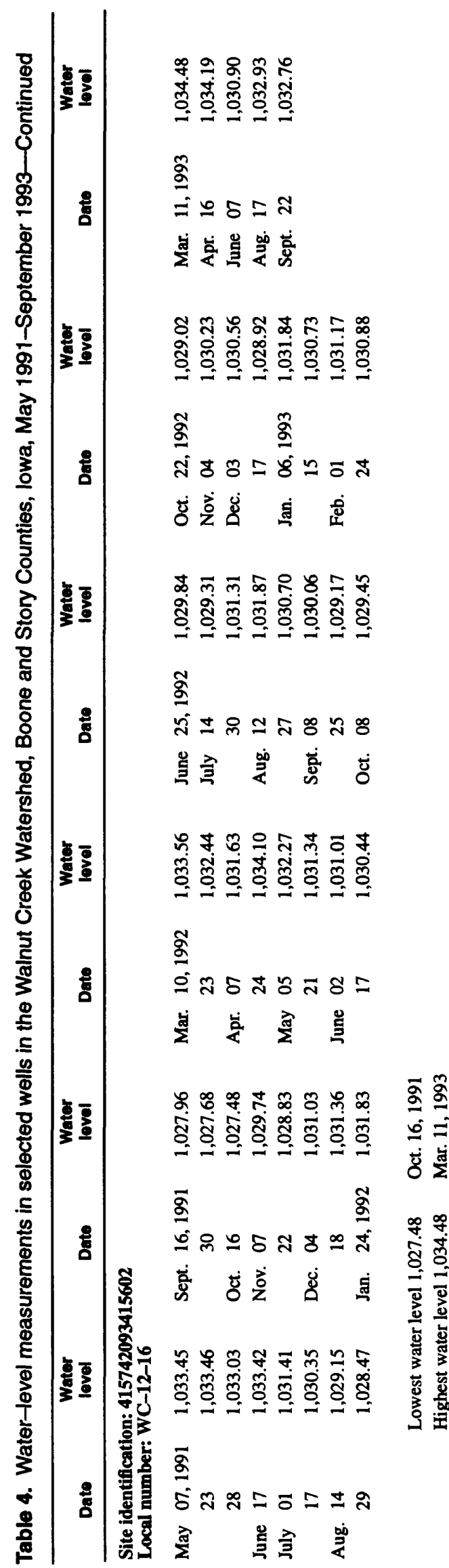

万ํำ 드

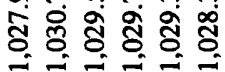

๙

총ำ

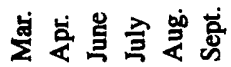

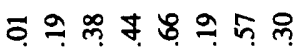

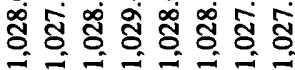

สิ

ㄷㅇㅇㅛ

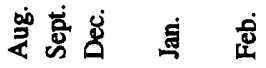

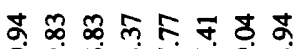

ర్ర

รั

สำส

晏要晋照

$\stackrel{\infty}{\infty} \infty \approx \infty \sim \infty$

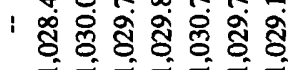

ริ รั

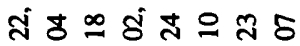

完岁 严 峞

รั ส

宅 से

傼客

$\bar{s}$

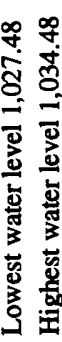

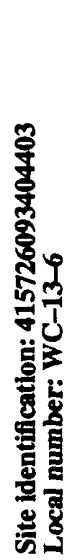

ลิ่ำㅇำテ5\%

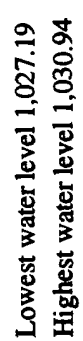

若 若

क ำ ल ำ

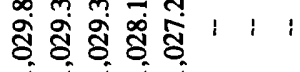

5

สิ

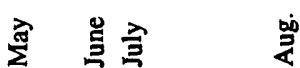

ำㅇํㅇำㄴำ

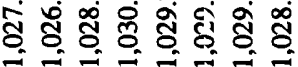

๙

ฮั

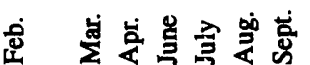

పำ

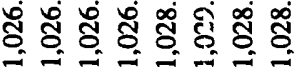

รั

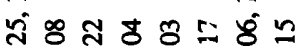

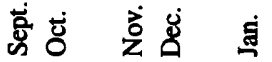

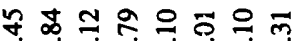

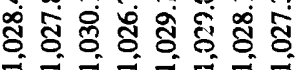

รั

ภำะภะละ

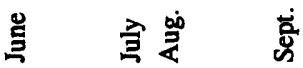

ฟ

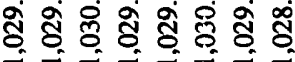

รั

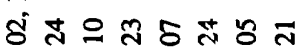

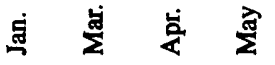

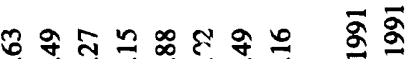

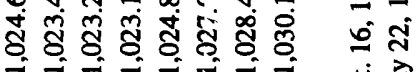

हुं

$\bar{s}$

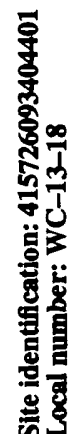

ลิำㄴำ

$\stackrel{\square}{m}$

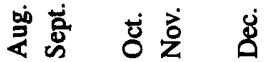

二

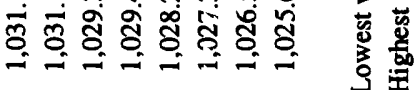

\section{ธ్丶}

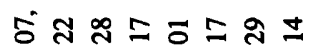

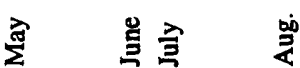




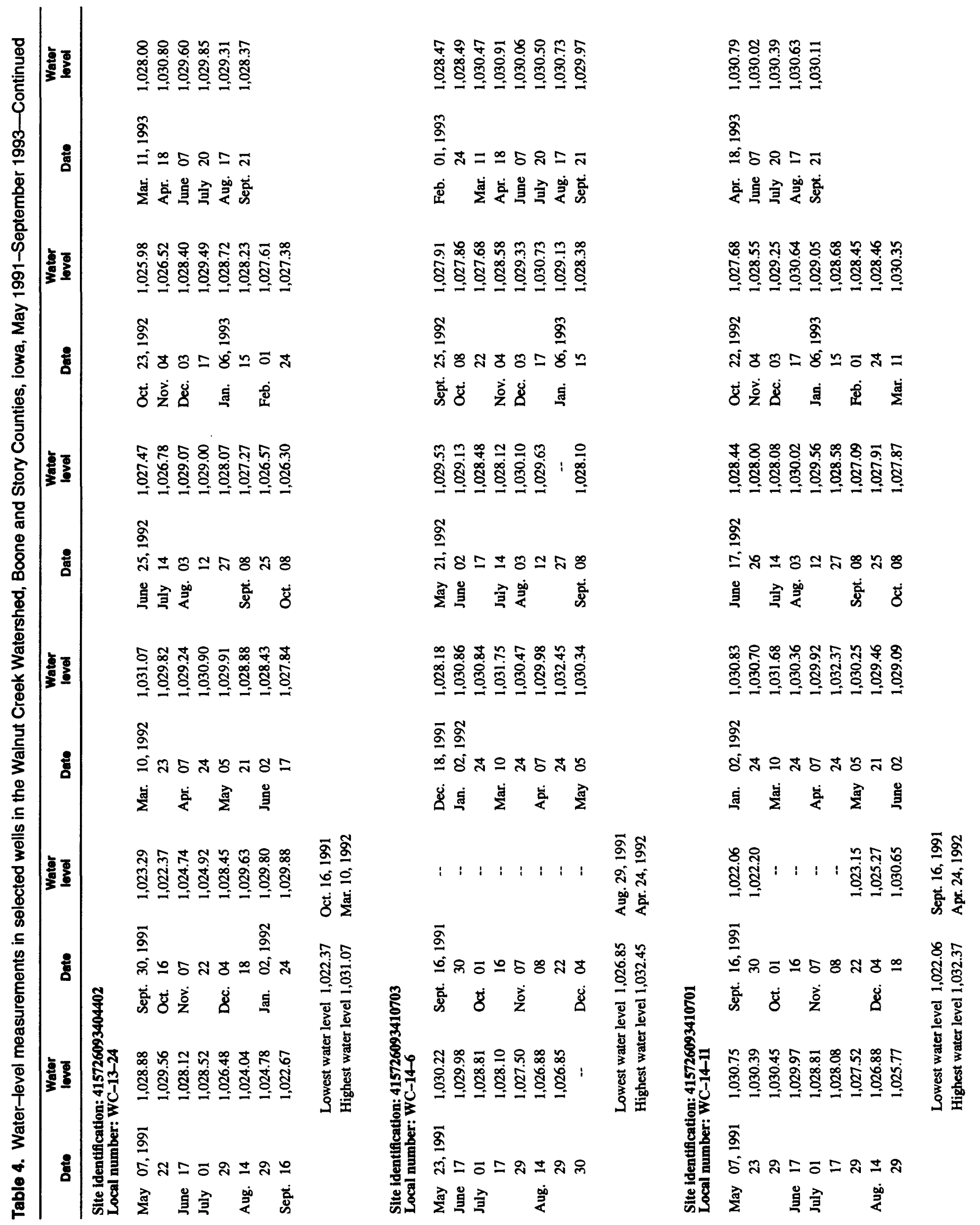




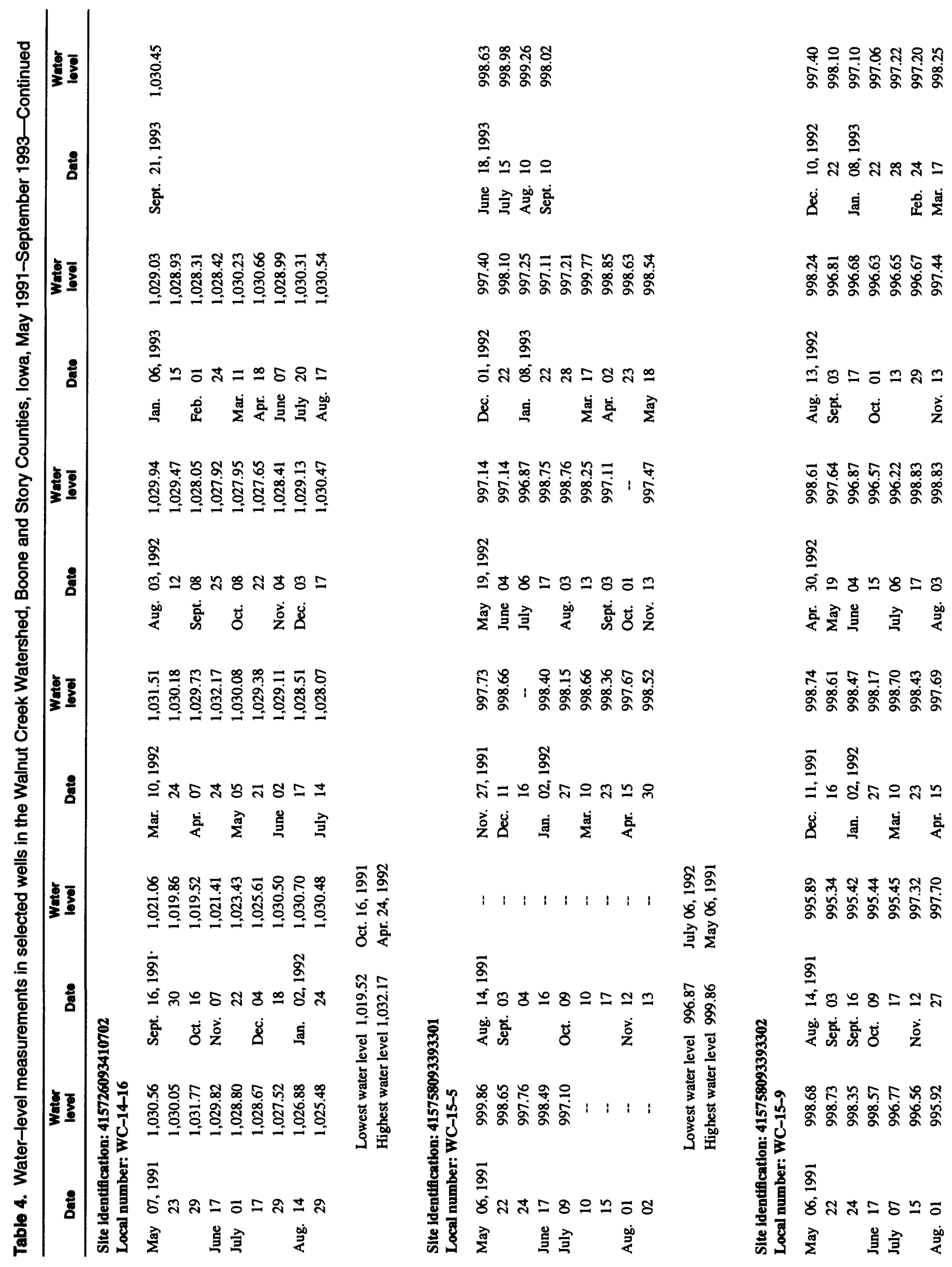




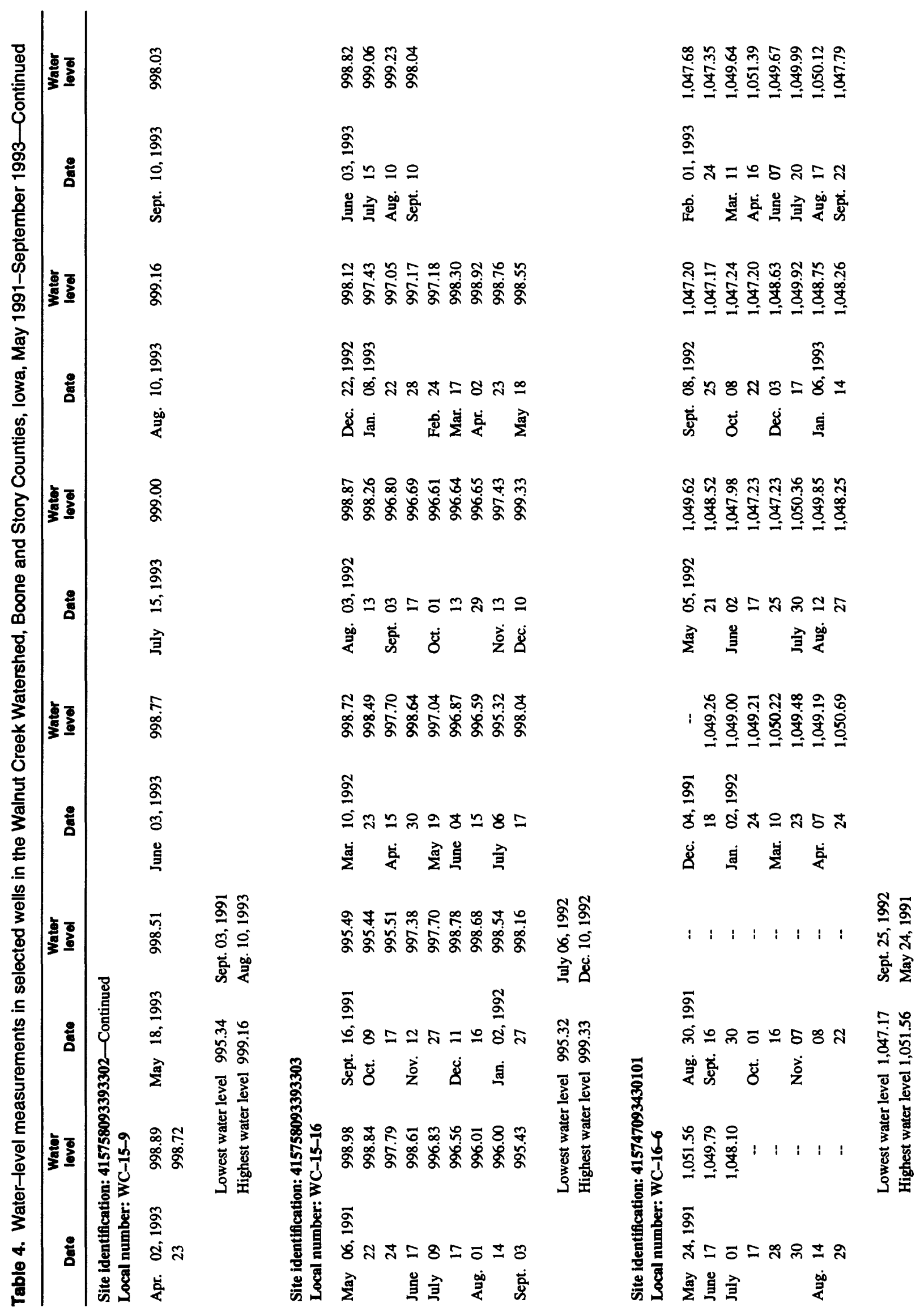




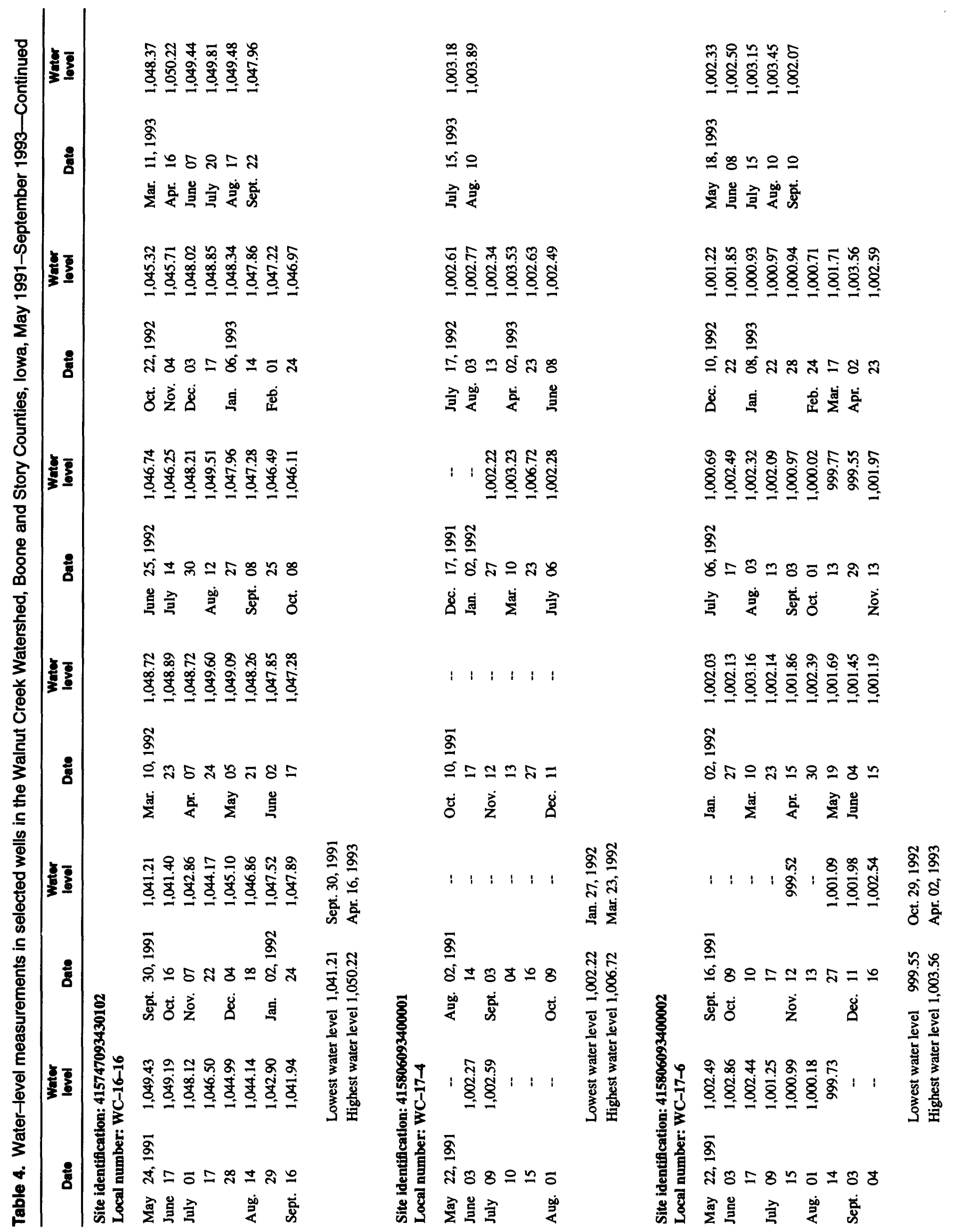




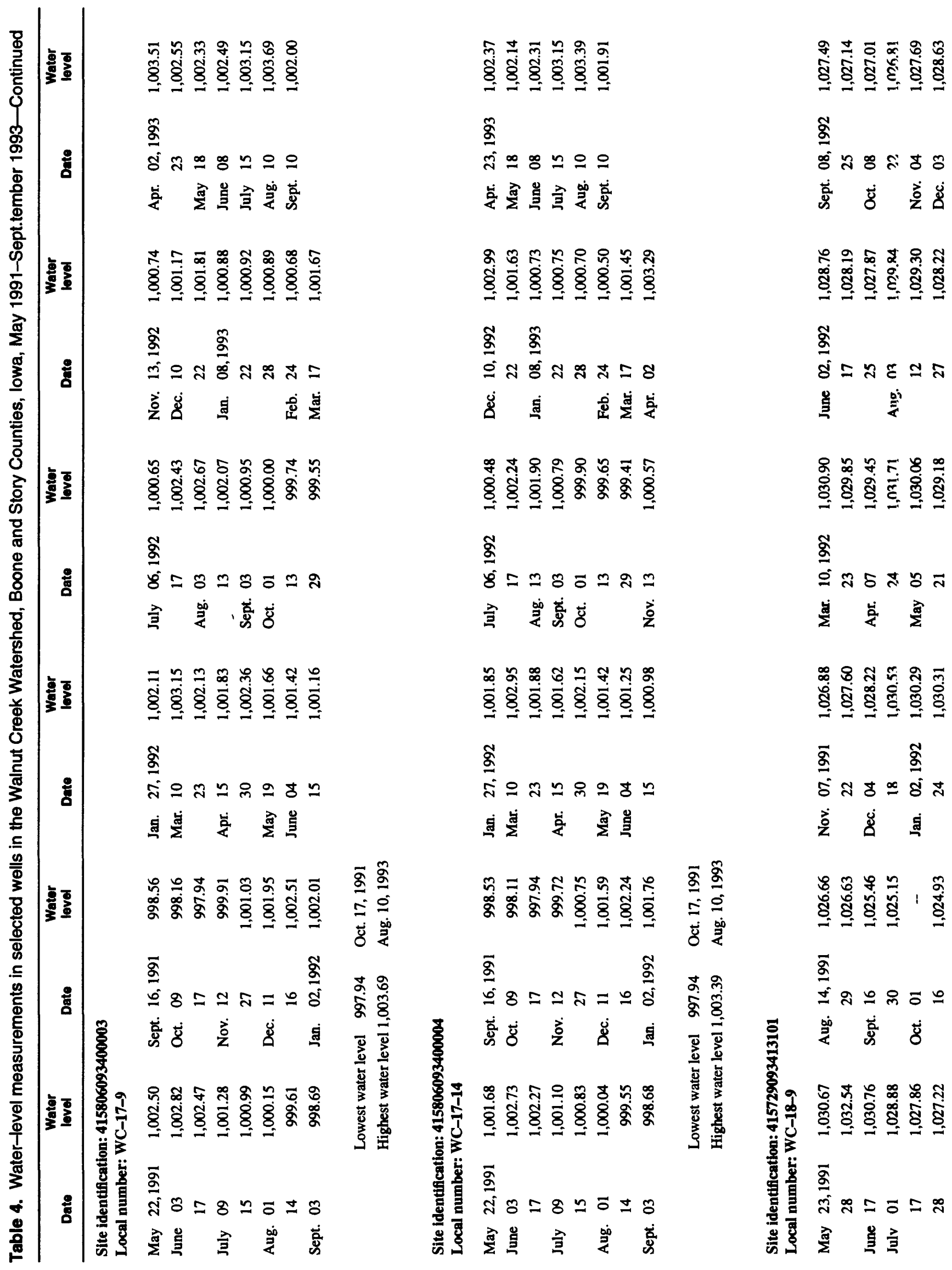




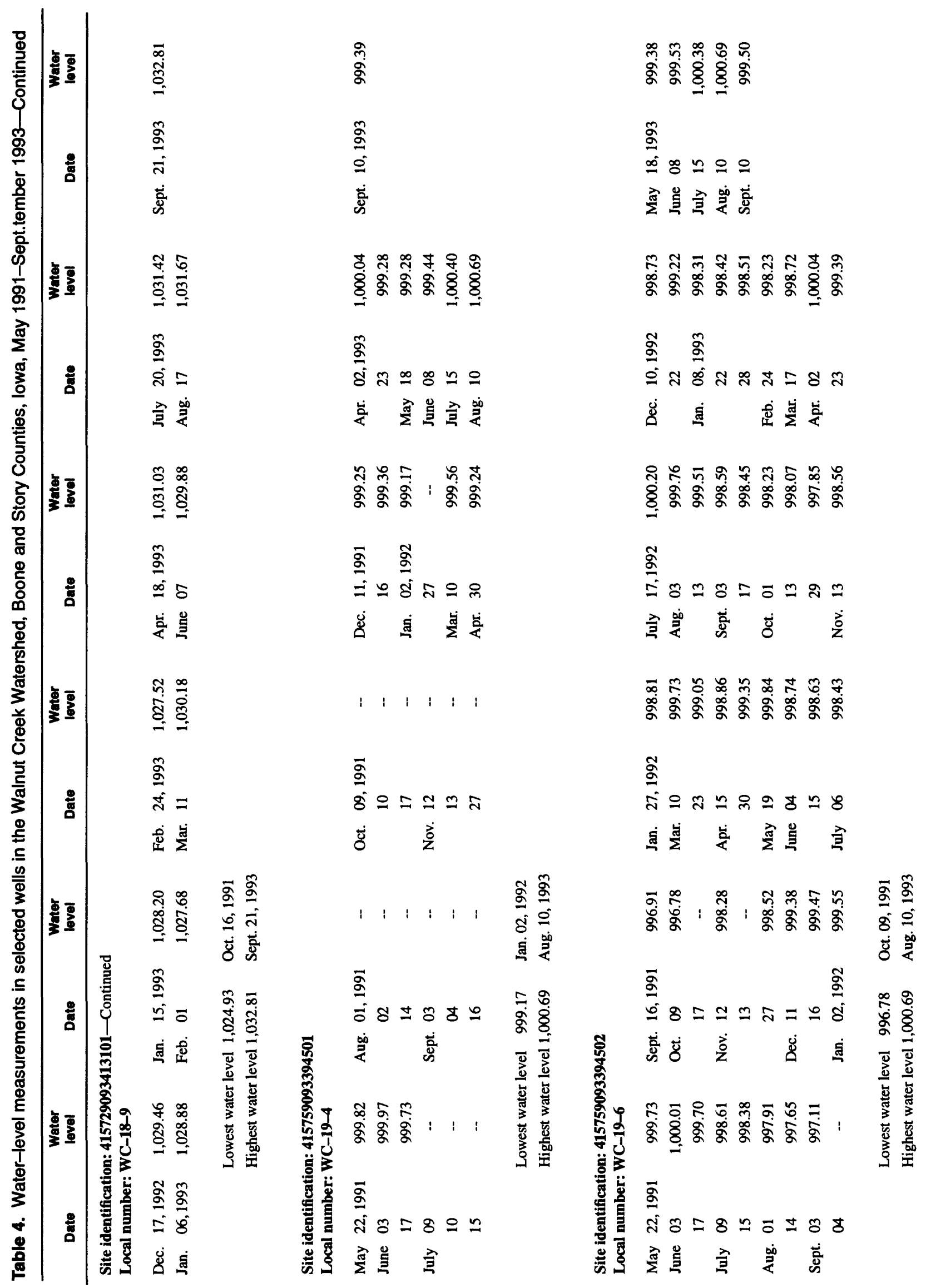




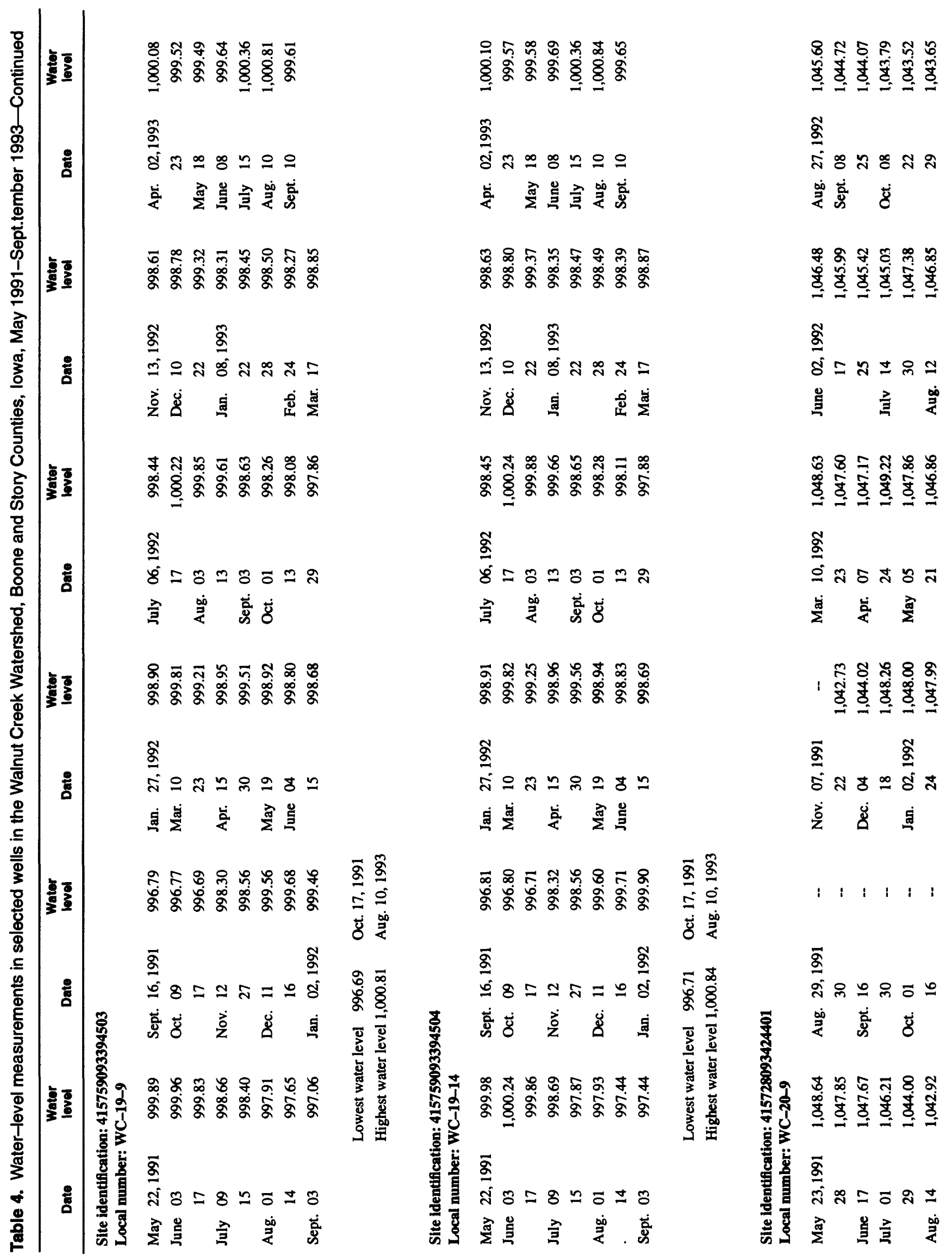




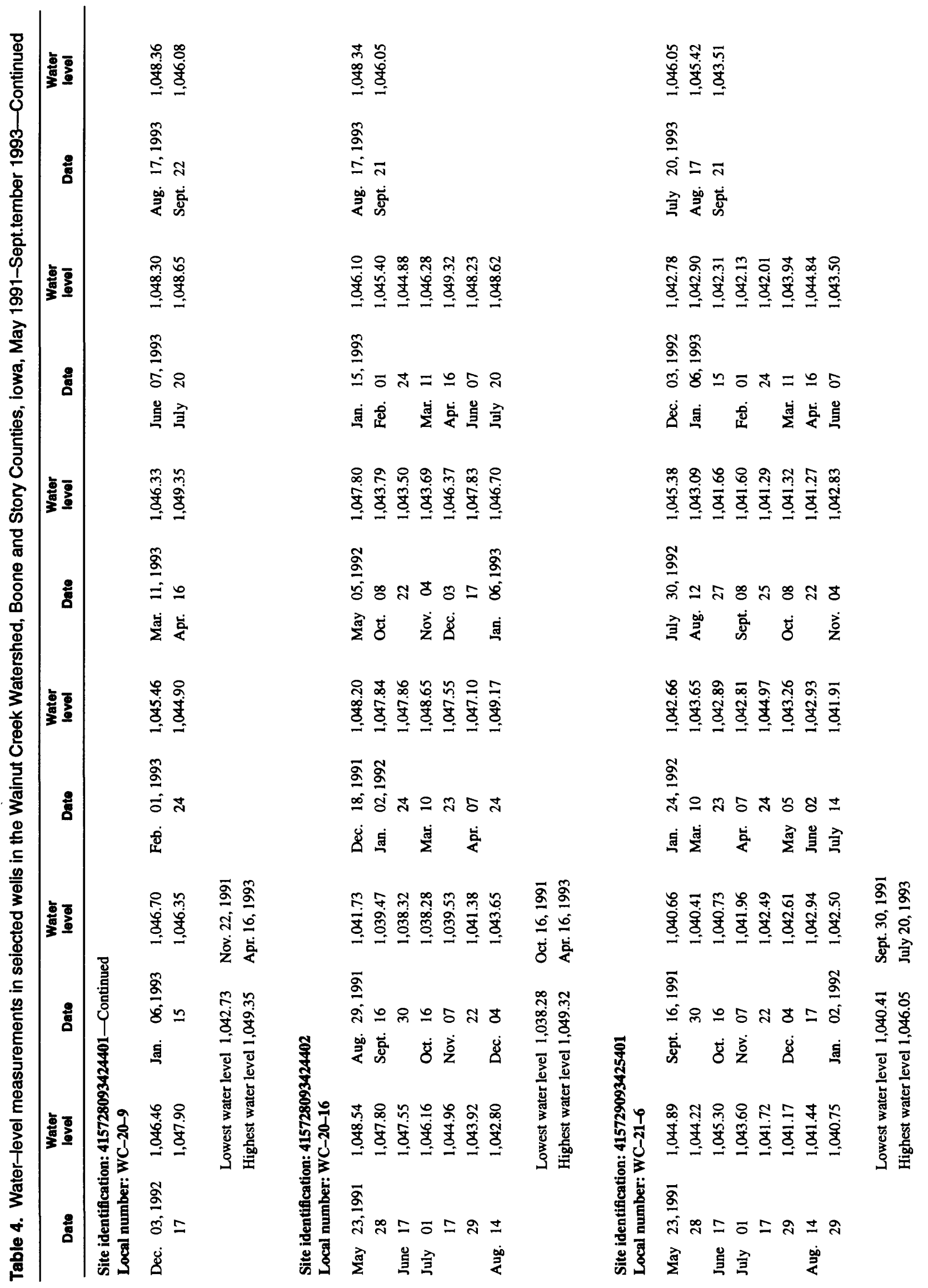




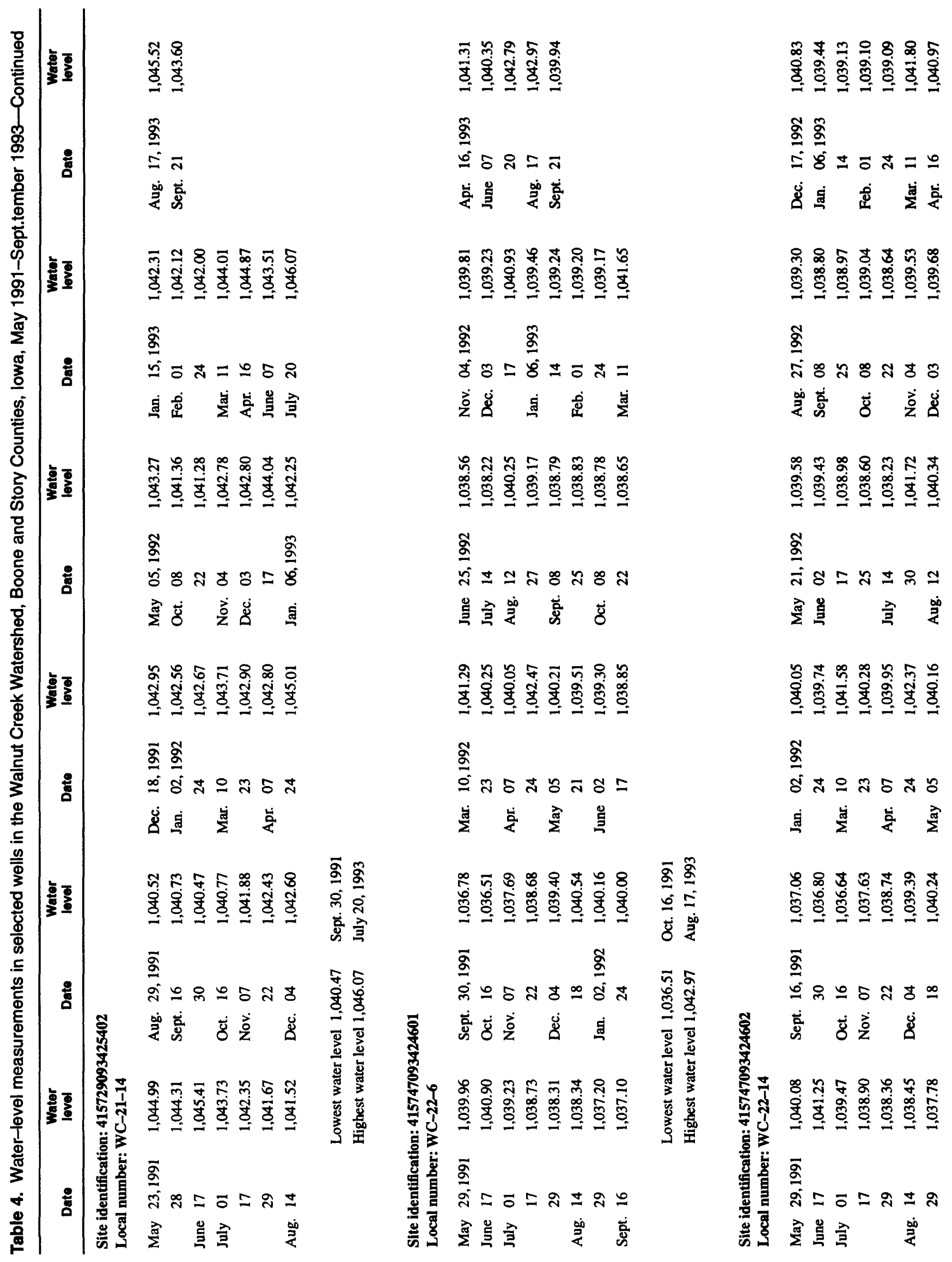




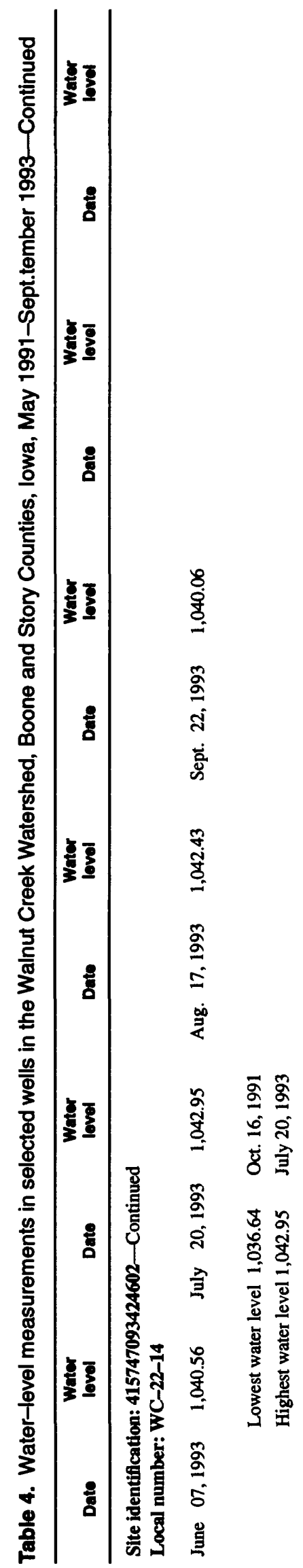

की

의월ำ

๙ิ

\%

$\dot{n}=05$

สั รั

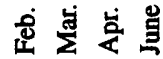

$\therefore 8 \div 4=25$

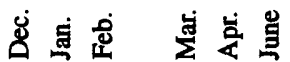

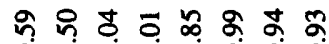

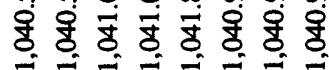

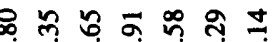

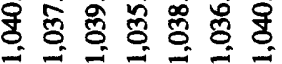

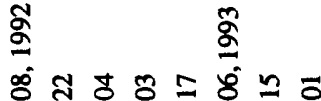

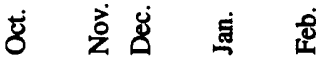

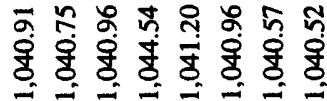

รั

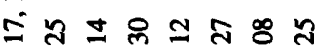

总 斑 皆

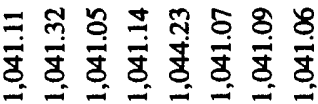

ฐิ

ㅊํㅇำㄴำ

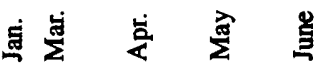

ลั

ส่

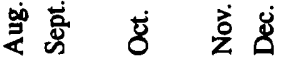

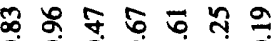

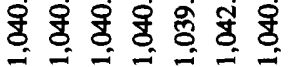

ริ

สํㅇำ

嘼喜主㐫

궁요 \% 용

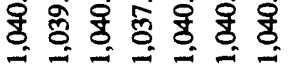

g

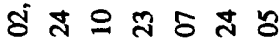

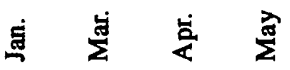

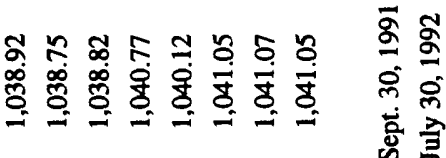

8ㄷ

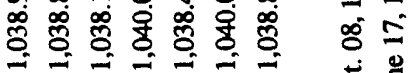

Б)

อิ

वี.

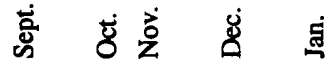

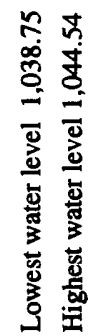

$\bar{g}$

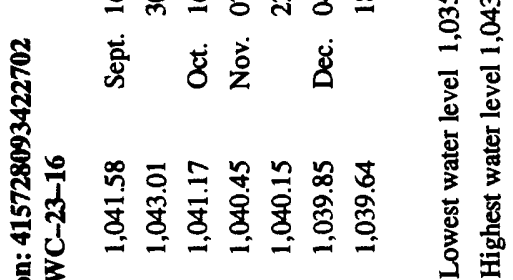

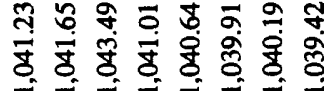

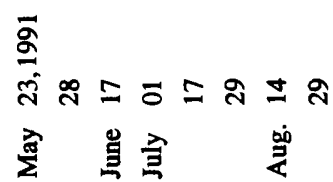

$\overline{2}$

$\vec{\pi}=\overline{0}=2 \pm \therefore$

密焉壱交㐫 


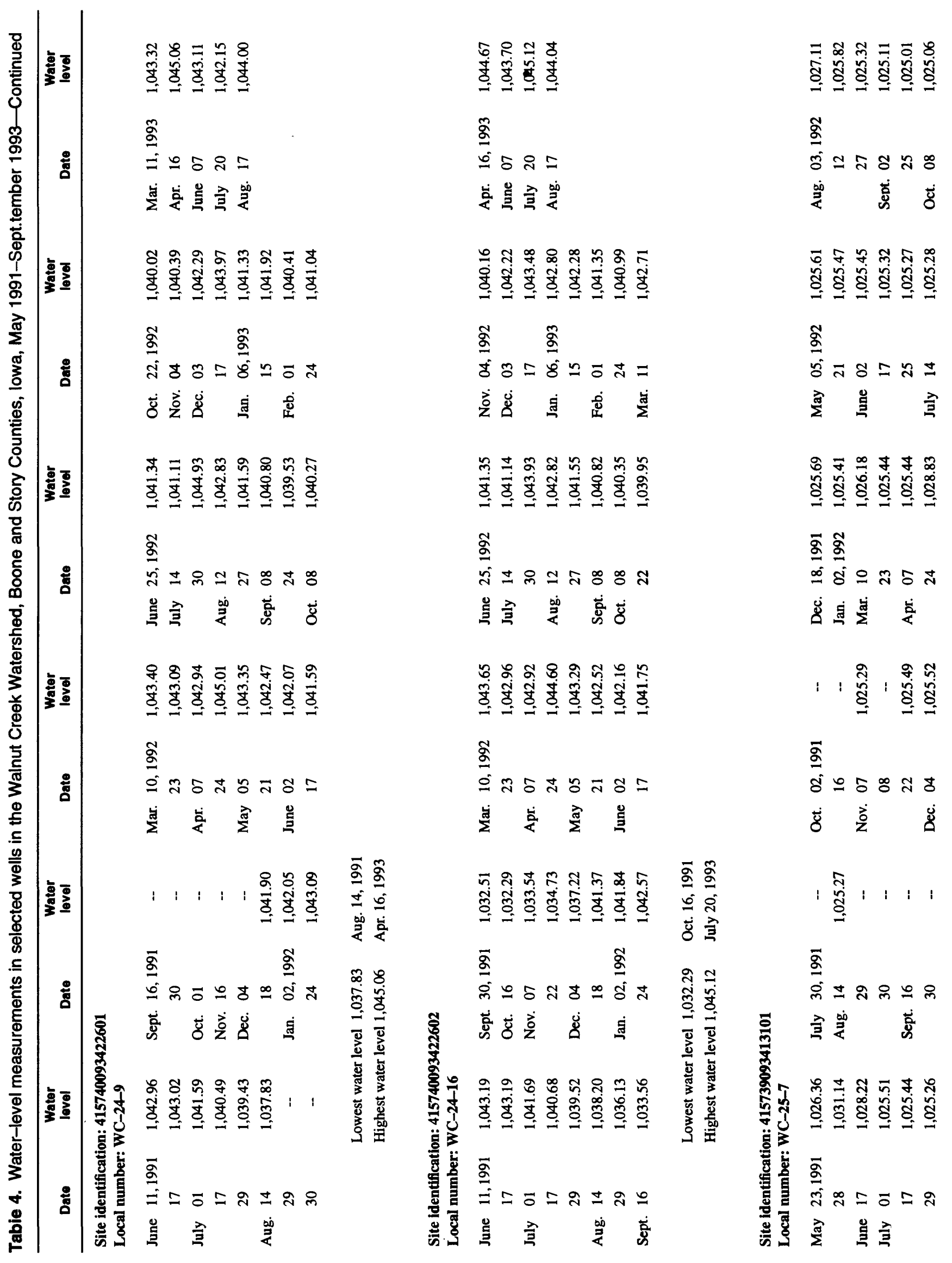




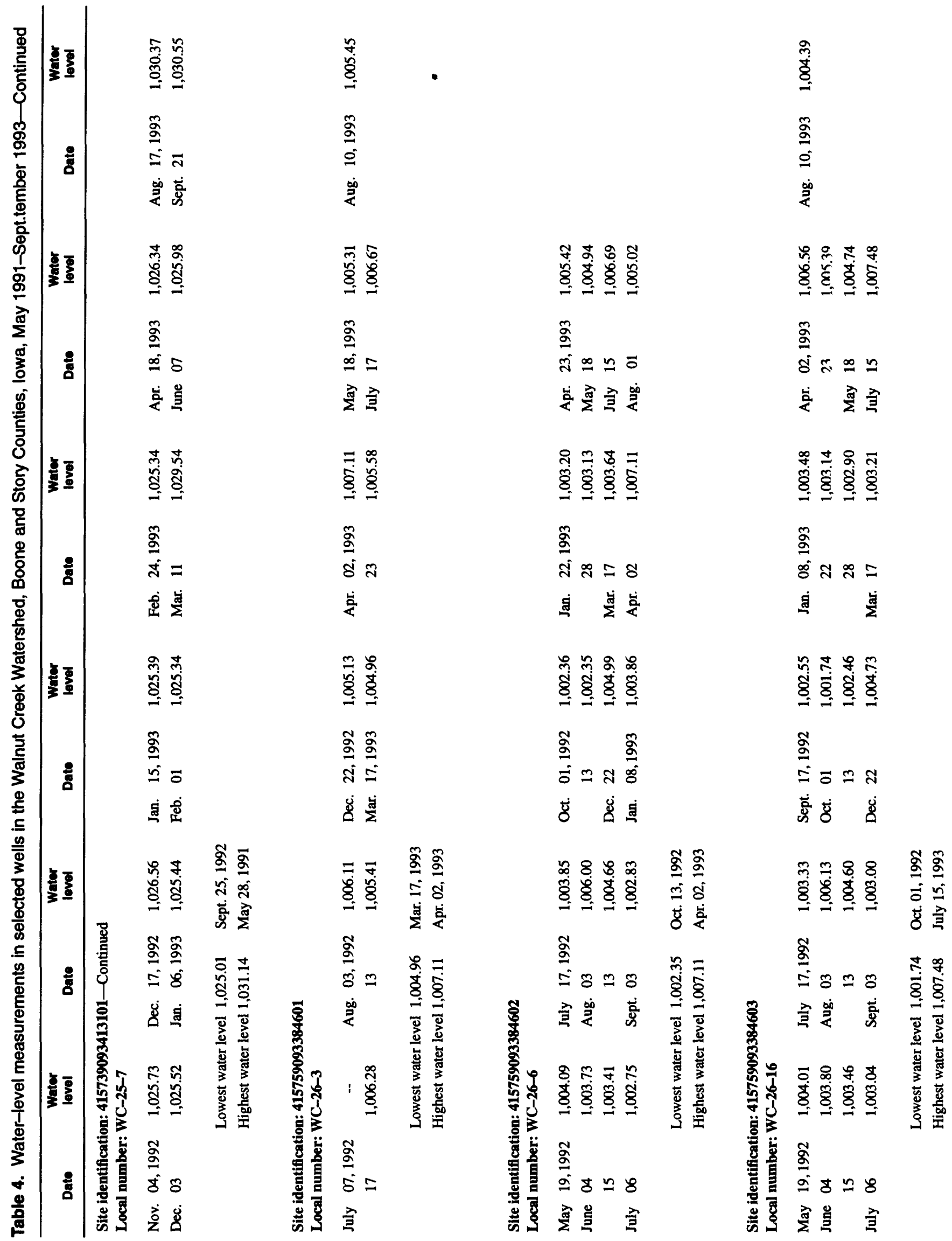




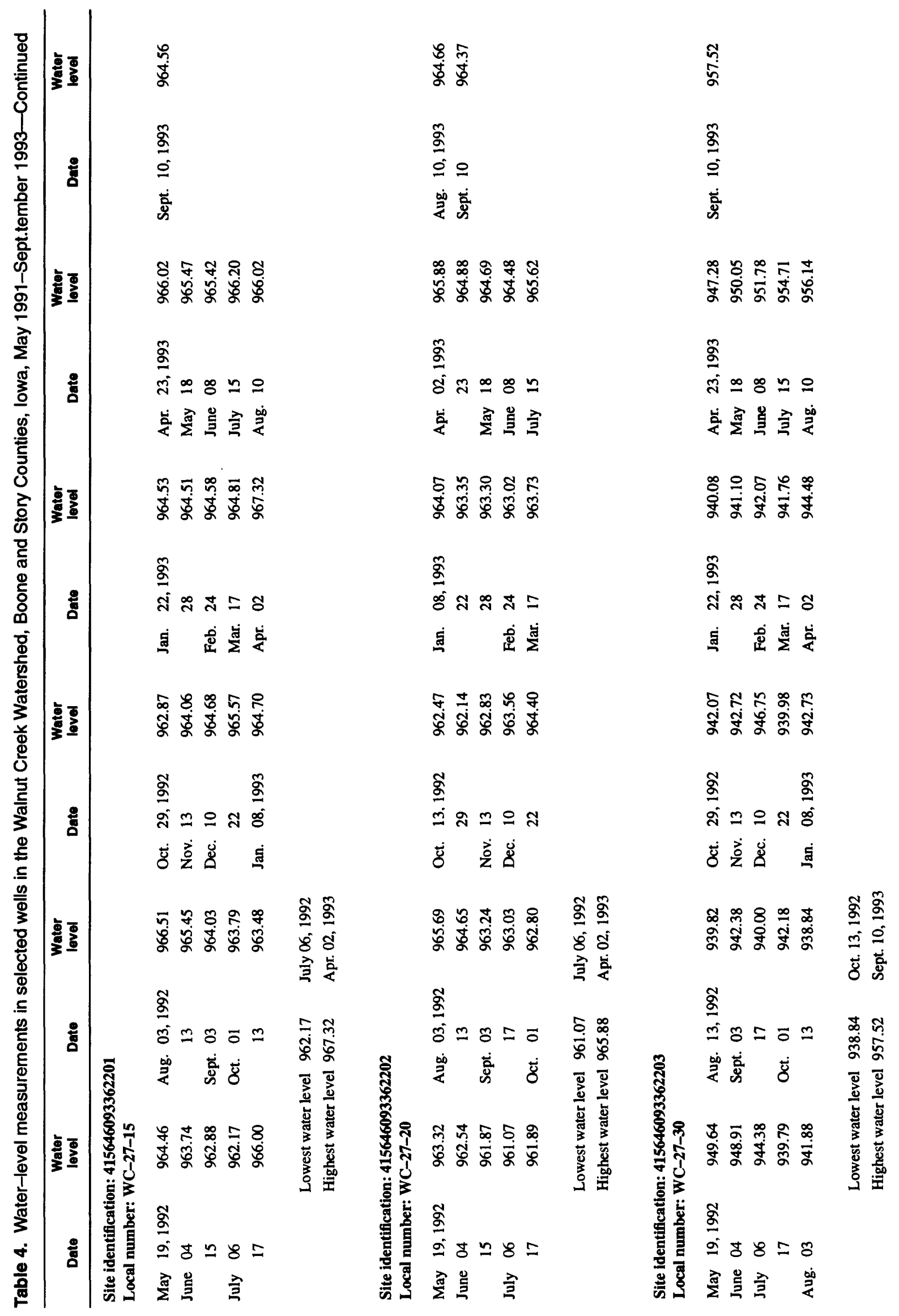




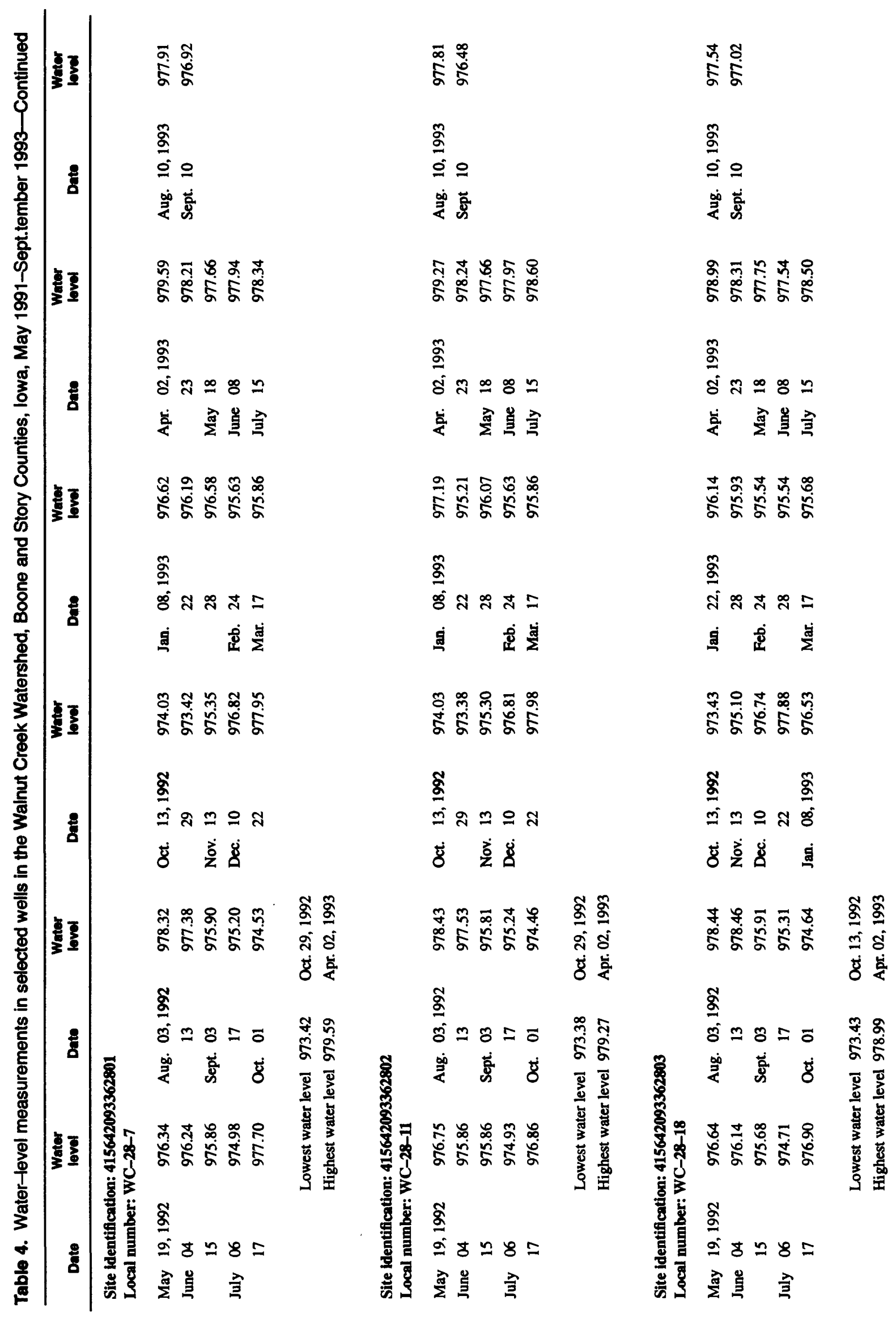




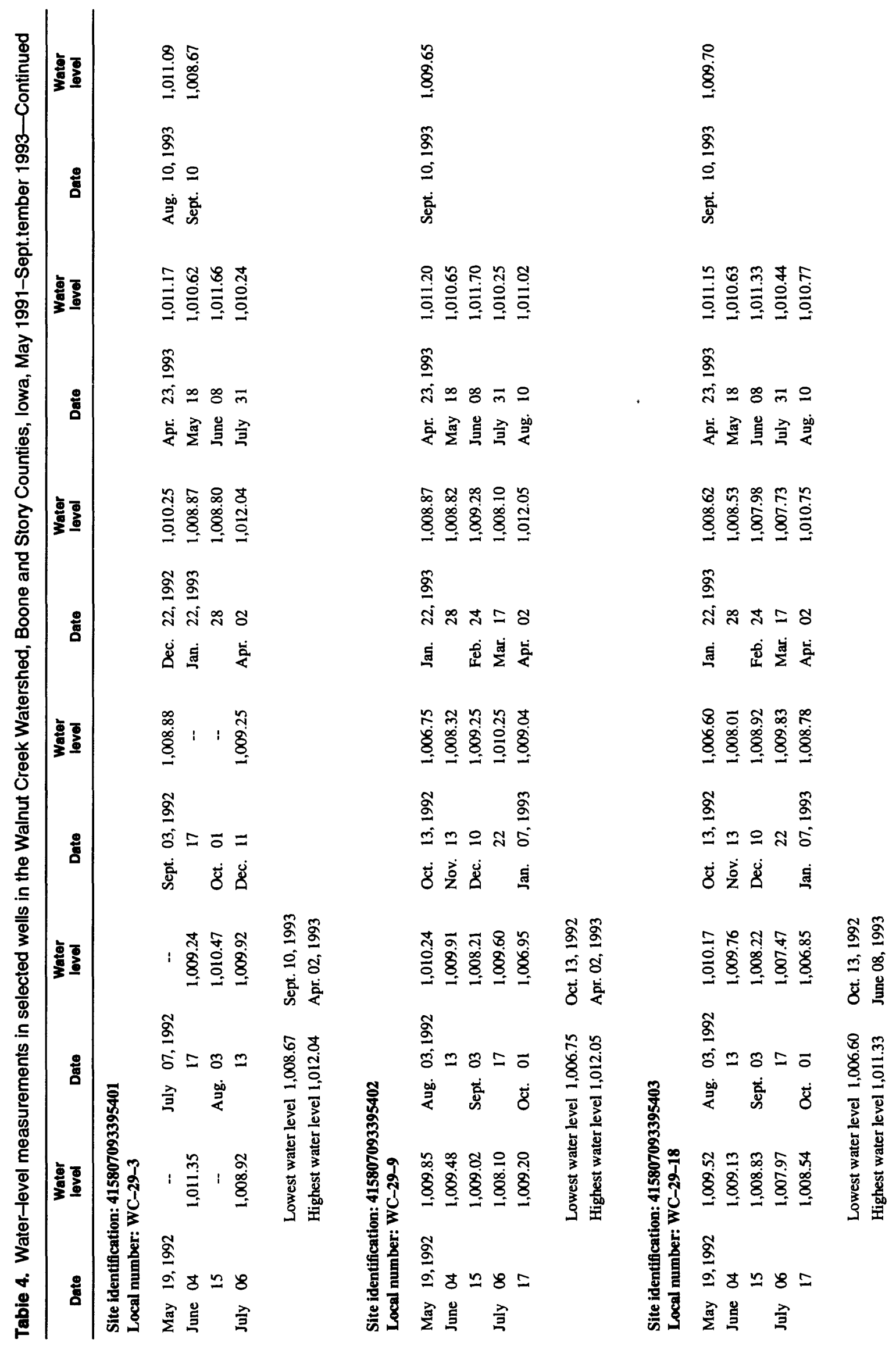




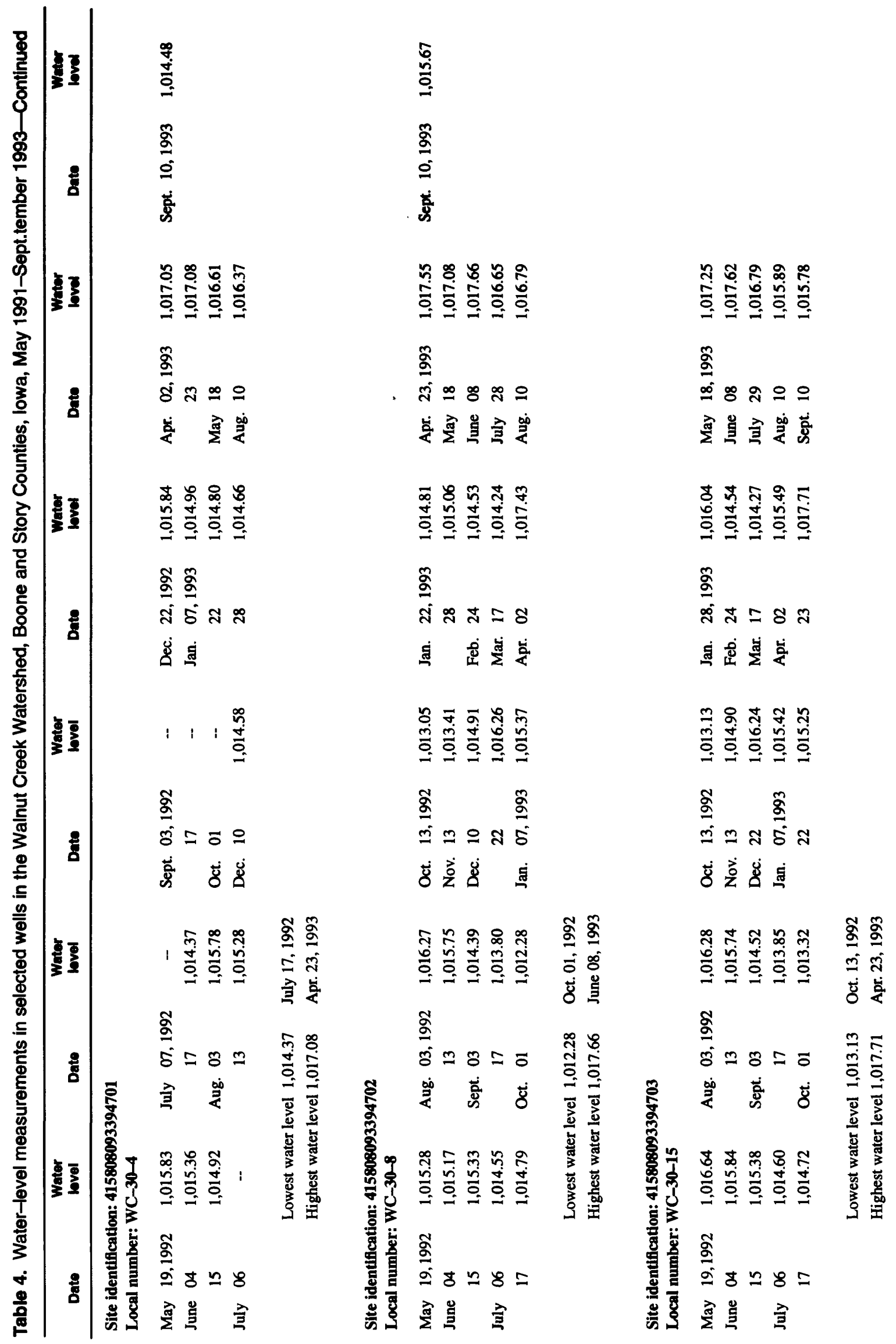




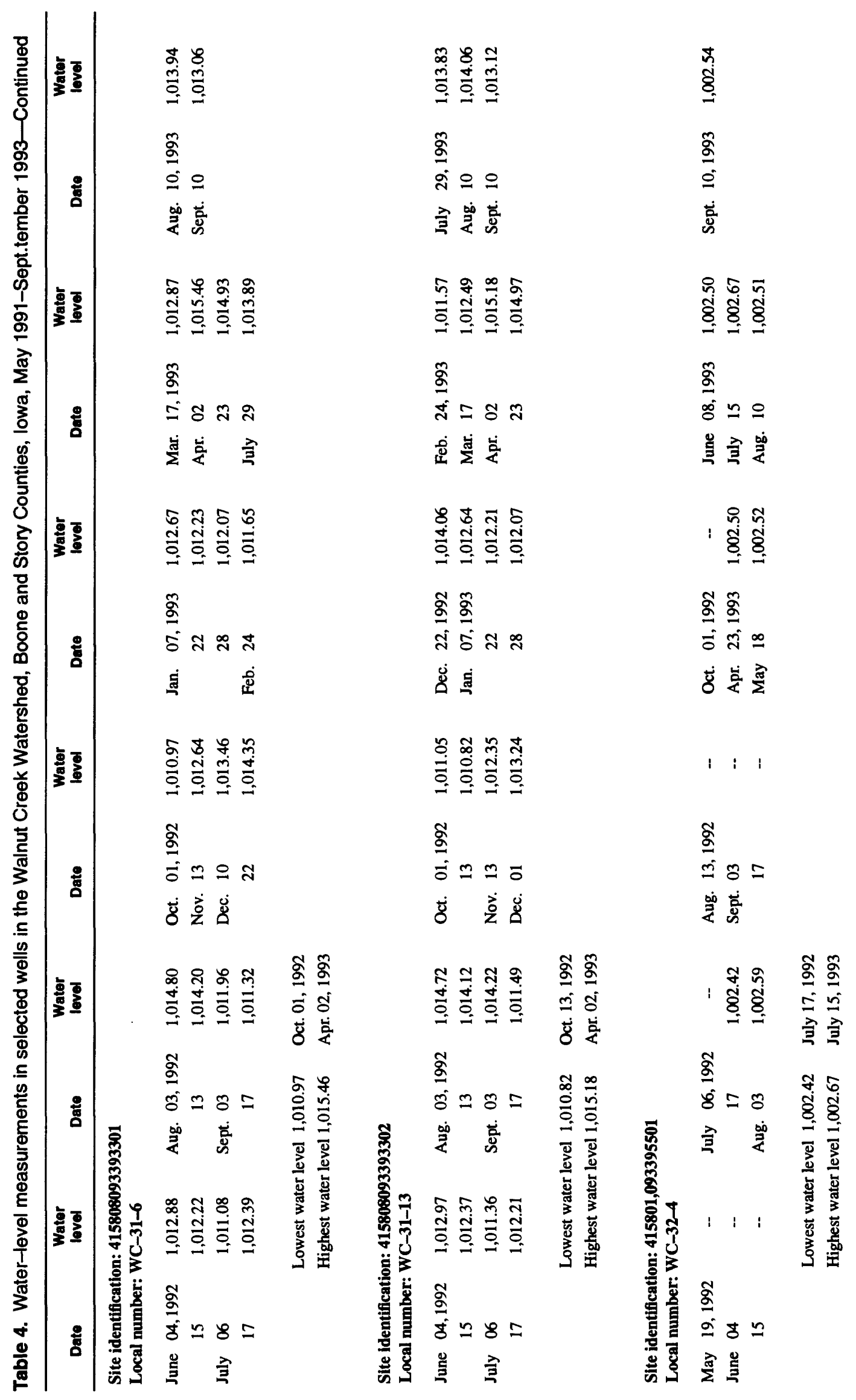




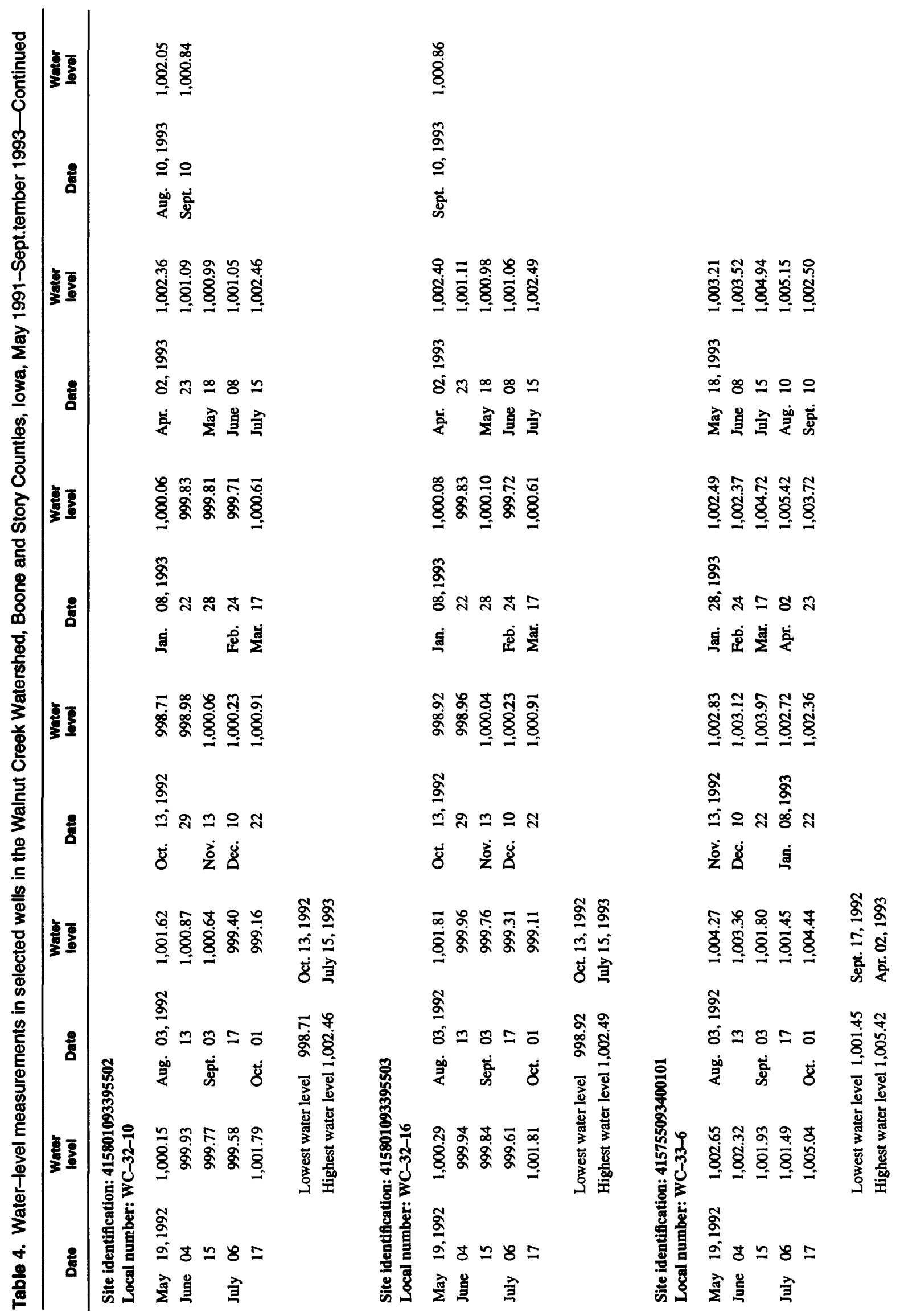




\begin{tabular}{|c|c|c|c|}
\hline 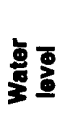 & 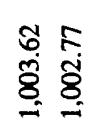 & $\begin{array}{l}\text { के } \\
\text { ळ. } \\
\text { o }\end{array}$ & 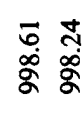 \\
\hline 8 & $\begin{array}{l}\stackrel{\Omega}{\sigma} \\
\stackrel{0}{\sigma}\end{array}$ & $\frac{\Omega}{\Omega}$ & \\
\hline & 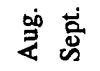 & 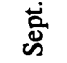 & \\
\hline
\end{tabular}

สุร ำ ㄷํㅇ

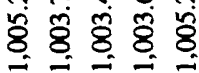

กี รั $\%$

ลूँ

ดे ल 8 के

कू बूे

\%

g

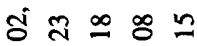

งิ

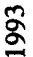

家禀总弯

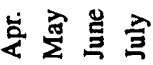

ธิ ก $\cong$

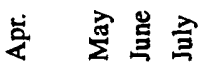

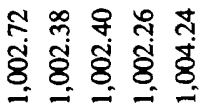

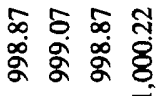

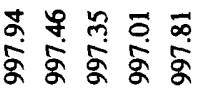

$\approx$

$\infty$

ลั

ปั่

\%

品 这

$\frac{8}{2}$

ถึ ส ส ส

寻 这

$\infty$ ต $₹$ \&

क्ष

Sू

ำกำล

安完岁

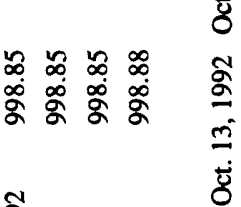

ริ

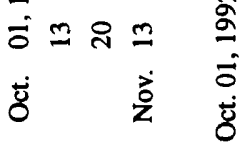

กิร

品卷客客

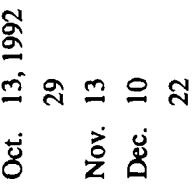

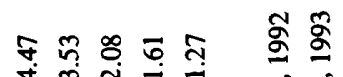

8.

๓๐ळ

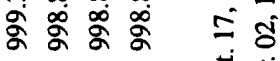

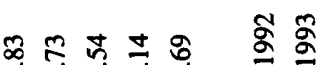

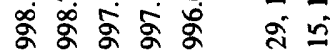

安荌

รั

का $m=-\infty \pi$

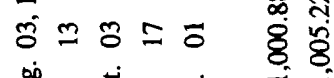

递营若

离

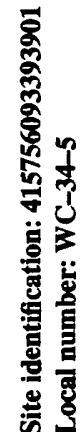

รั

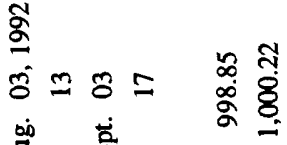

离

ธิ ㅇํ ఫ

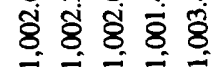

ลั

รั

a $208=$

要总齐

离

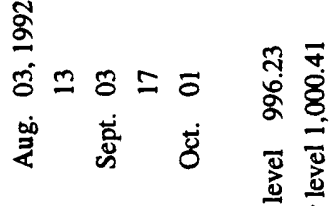

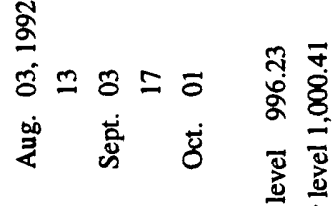

ष्ठㅇ 츨

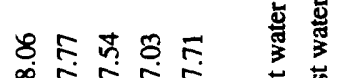

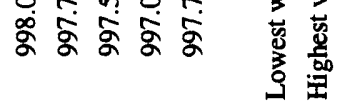

รั

워 $\simeq=$

ळ

9 $08=$

离总

要总交 


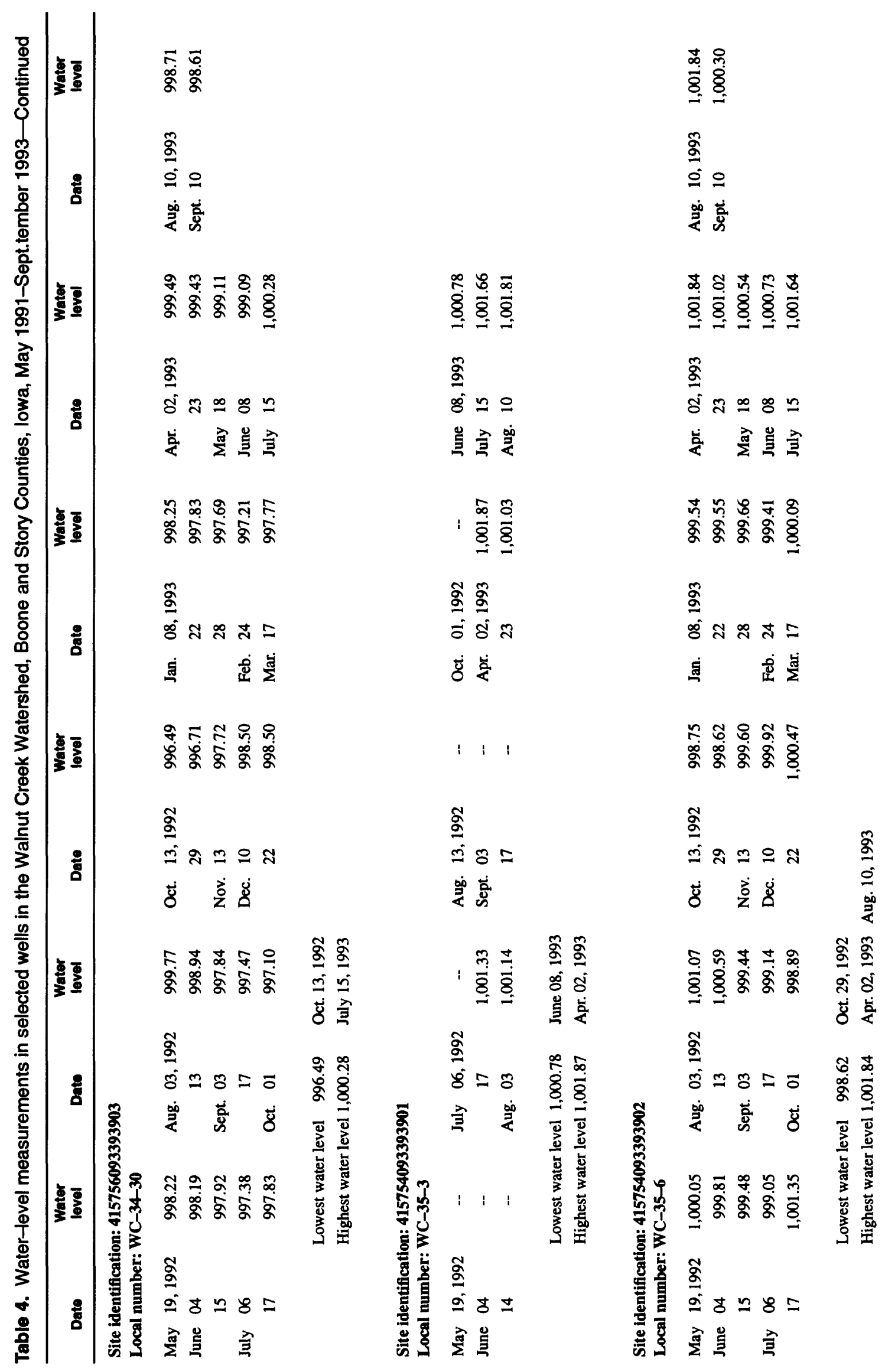




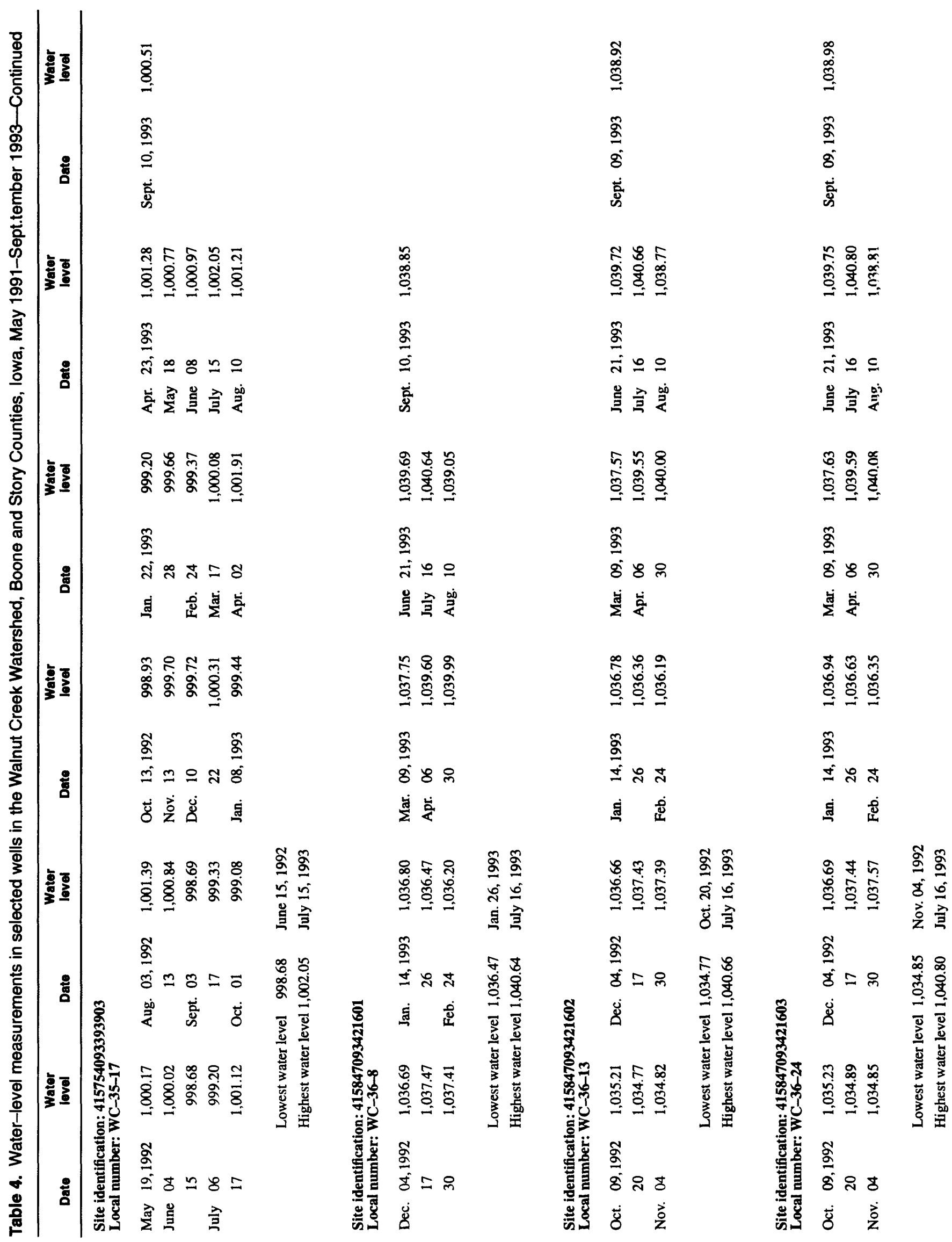




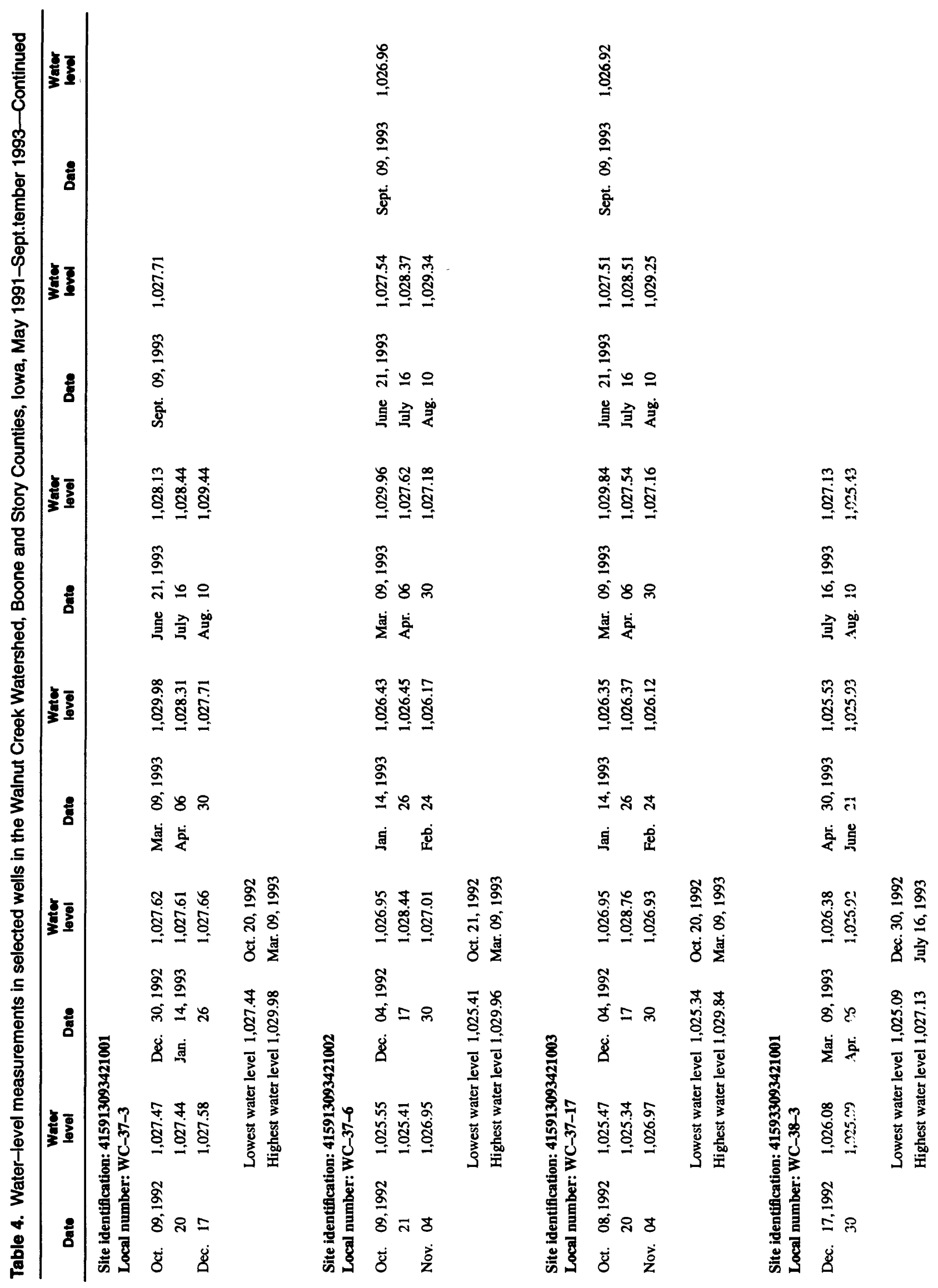

68 Ground-Water Levels and Flow at Selected Study Sites in the Walnut Creek Management System Evaluation Area, Boone and Story Countles, lowa, 1991-93 


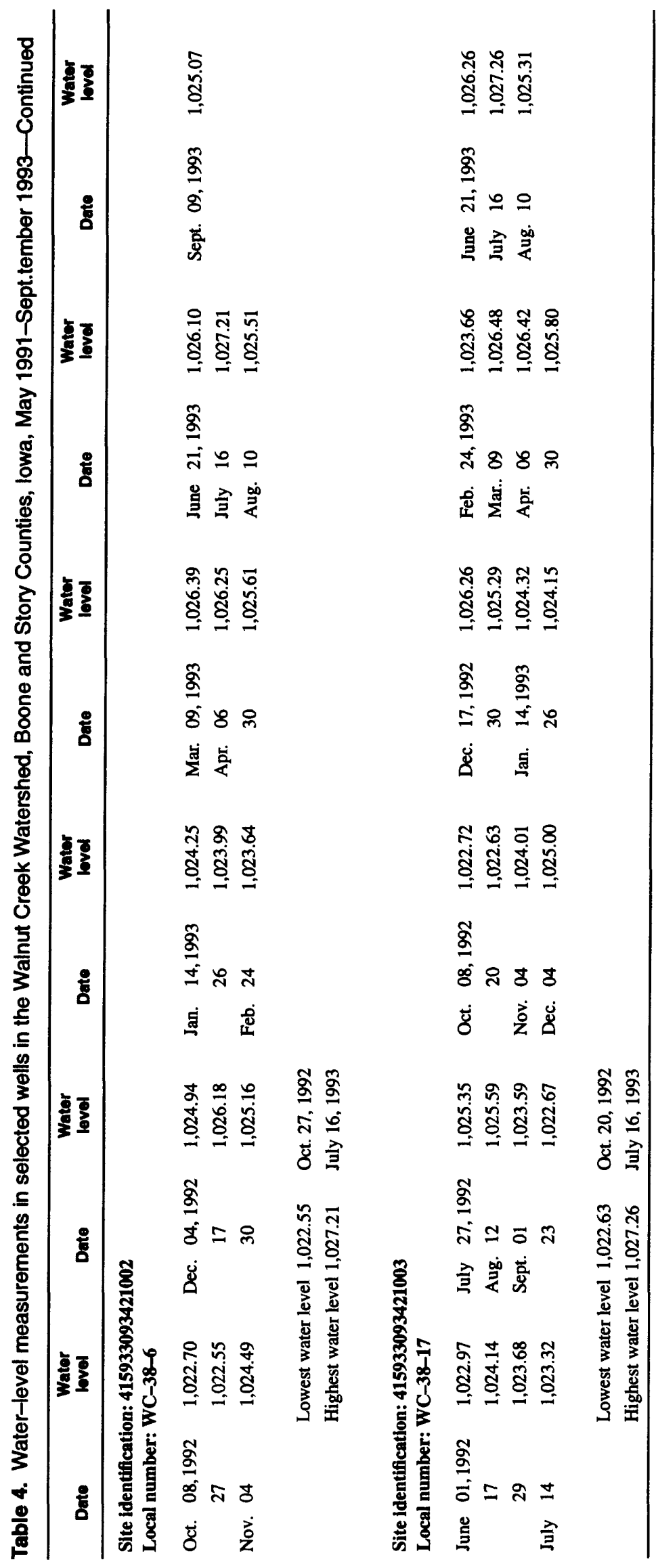

